\title{
A Mendelian Randomization dictionary: Useful definitions and descriptions for undertaking, understanding and interpreting Mendelian Randomization studies
}

Deborah A Lawlor *1,2,3, Kaitlin H Wade *1,2, Maria Carolina Borges ${ }^{1,2}$, Tom Palmer ${ }^{4}$, Fernando Pires Hartwig1,5, Gibran Hemani1,2, Jack Bowden ${ }^{1,2}$.

${ }^{1}$ MRC Integrative Epidemiology Unit at the University of Bristol, Bristol, UK

2 Population Health Sciences, Bristol Medical School, University of Bristol, Bristol, UK

${ }^{3}$ Bristol NIHR Biomedical Research Centre, Bristol, UK

${ }^{4}$ Department of Mathematics and Statistics, Lancaster University, Lancaster, UK

5 Postgraduate Programme in Epidemiology, Federal University of Pelotas, Pelotas, Brazil

* Equal contributions and joint senior and corresponding authors

\section{Standfirst}

As Mendelian randomization (MR) becomes more commonplace in clinical guidelines and drug development, the aim of the MR Dictionary is to provide useful definitions and descriptions for undertaking, understanding and interpreting MR studies to a wide, inter-disciplinary audienceboth those new to MR and those who are experienced in its use but who want to remain up to date.

\section{Corresponding authors:}

DA Lawlor, MRC Integrative Epidemiology Unit at the University of Bristol, Oakfield House, Oakfield Grove, Bristol, UK. Email: d.a.lawlor@bristol.ac.uk

KH Wade, MRC Integrative Epidemiology Unit at the University of Bristol, Oakfield House, Oakfield Grove, Bristol, UK. Email: Kaitlin.Wade@bristol.ac.uk

Contributors: All authors provided a substantial contribution to the design and content of the MR Dictionary, as well as writing and revising drafts based on comments received, and approving the final version. 
Funding: This work was supported by: Medical Research Council (MRC) and the University of Bristol who fund the MRC Integrative Epidemiology Unit [MC_UU_00011/6 and MC_UU_00011/2] and the NIHR Biomedical Research Centre at University Hospitals Bristol NHS Foundation Trust and the University of Bristol. DAL's contribution is supported by the British Heart Foundation [AA/18/7/34219], US National Institutes of Health [R01 DK10324], European Research Council [669545] and UK National Institute of Health Research [NF-0616-10102]. KHW was supported by the Wellcome Trust Investigator award (202802/Z/16/Z; PI: Nicholas Timpson] at the start of this project and is now supported by the Elizabeth Blackwell Institute for Health Research, University of Bristol and the Wellcome Trust Institutional Strategic Support Fund [204813/Z/16/Z]; MCB is supported by MRC Skills Development Fellowship [MR/P014054/1]; and GH is supported by the Wellcome Trust and the Royal Society $[208806 / \mathrm{Z} / 17 / \mathrm{Z}]$.

Acknowledgements: The following provided useful comments on a draft of the dictionary: Tim Frayling (University of Exeter, UK), Rachel Freathy (University of Exeter, UK), Jackie Lane (The Broad Institute, USA), Neil Pearce (London School of Hygiene \& Tropical Medicine, UK), Martine Rutter (Manchester University, UK), Jess Tyrrell (University of Exeter, UK). The authors take full responsibility for all content.

Conflicts: DAL has received support from government, charity and industry funders, including Roche Diagnostics and Medtronic for research unrelated to this paper. All other authors declare no conflicts of interest. 


\section{Introduction}

Mendelian randomization (MR) is the use of genetic variants as instrumental variables (IVs) to interrogate the causal effects of modifiable risk factors on disease or other outcomes. It was first formally proposed in 2003 (1), following archetypal examples that used genetics, or suggested their use, to infer causality in epidemiological associations (2,3). Over the last 15 years, it has been increasingly used to improve understanding of the causal effects of lifestyle risk factors (4-7), biomarkers $(8,9)$ and drug treatments (10-12) on human health. Alongside these applications, considerable efforts have been undertaken to develop tools for exploring the underlying assumptions of MR and the robustness of results from MR studies (13-21). Methods for using MR in different contexts, including using both individual- and summary-level data and testing the joint effects of two or more risk factors, understanding mediating mechanisms and long-term effects of risk factors measured in pregnant women on their offspring, have also been developed and applied (22-27). The rapidly advancing field of MR methodology has generated a new language that reflects the multi-disciplinary contributions to the field, with terms originating from epidemiology, econometrics, genetics and biostatistics. As MR becomes more commonplace in clinical guidelines, drug development and the identification of targets for lifestyle interventions $(28,29)$, there is a need for researchers and practitioners from multiple disciplines to understand the existing and evolving 'language' of MR.

There are several publications that describe the underlying principles of MR and/or provide up-to-date descriptions of emerging novel methods, several of which include glossaries of useful terms in MR (29-33). However, many of these are tailored to specific audiences and we are not aware of an extensive "MR Dictionary" that provides useful definitions and descriptions for undertaking, understanding and interpreting MR studies to a wide, inter-disciplinary audience. Such a resource should be valuable to clinicians, other clinical and public health practitioners as well as to researchers from difference disciplines, including those new to MR, as well as those who are experienced in its use but want to remain up to date. Previous papers and glossaries do not extensively cover the increasing number of different statistical methods that 
can be used in MR, nor do they have the commitment and a process for regular updating, as we plan to do here.

The aim of this dictionary is to provide definitions and key references for terms and concepts that are necessary to undertake MR studies, and to critically appraise and appropriately interpret findings from MR studies.

\section{Layout of the dictionary}

The MR Dictionary is split into 11 chapters: the first ten contain tables that define terms in broad areas, providing a definition for each term, additional information (e.g., relevance to MR or assumptions of statistical methods) and key references, websites or figures for further clarification. These ten chapters cover the following areas:

- Chapter 1 - Genetic terms useful for understanding MR.

- Chapter 2 - Defining MR and different types of MR studies.

- Chapter 3 - Pertinent study designs, such as genome-wide association studies, or approaches that are related to MR.

- Chapter 4 - Common terms used when describing sources of bias or limitations specific to MR.

can currently be used to conduct MR analyses and estimate causal effects:

- Chapter 5 - Standard one-sample MR methods.

- Chapter 6 - Pleiotropy-robust one-sample MR methods.

- Chapter 7 - Standard methods for two-sample MR.

- Chapter 8 - Pleiotropy robust two-sample MR methods.

- Chapter 9 - Model selection and averaging approaches for two-sample MR.

- Chapter 10 - Heterogeneity and outlier detection methods for two-sample MR. 
The idea behind these separate chapters is that we envisage different users of this

dictionary to have different broad areas of interest or needs in relation to undertaking or interpreting MR studies. However, for those who wish to quickly search for a specific term, the index (at the end of the dictionary) provides a complete list of all terms in any of the tables in alphabetical order. In addition, within each of the chapters, terms are presented alphabetically and, to help readers identify terms that are described in any of the chapters, we have crossreferenced (using hyperlinks, indicated in italics) any terms that are defined in any of the chapters included in the MR Dictionary. For example, in the first entry of Chapter 1, the terms gene, locus, chromosome (and several others) are in italics. Holding the cursor over these terms (or any others that are italicised in any of the chapters) whilst pressing control and clicking take you to the main definition of that term.

All figures are numbered by chapter and order (e.g., Figure 1.1 is the first figure in Chapter 1). Chapter 2 (types of MR study) includes seven figures (Figure 2.1 to Figure 2.7), which are also referred to (and hyperlinked) in other chapters.

In the final chapter, Chapter 11, we provide links to some databases that support MR analyses, a link to an animation that describes MR and a flow diagram (Figure 11.1) that summarises how to undertake an MR study.

\section{Help us to keep the MR Dictionary sustainable and up to date}

We realise that it is difficult (nigh impossible) to ensure that this initial version of the Dictionary includes every term that all individuals interested in MR might wish to be included. We are also aware that new and relevant methods are certain to emerge after publication of this paper. We have tried hard to minimise any errors, but it is also likely that some readers may feel some entries need corrections. To manage these issues and ensure the Dictionary is sustainable and up to date, we will:

- Undertake an annual update of the MR Dictionary by the lead author group in August of each year. 

to release on the $B M J$ website in August 2020. This will support more rapid and extensive linked searches and more immediate updates and online discussion. The online platform will differ (and be an improved version) from the current full online word document version of the Dictionary in the following ways:

1. There will be a user-friendly interface that will allow users to enter and search for any term. The search will take them to the main definition but will also highlight all other 'chapters' in which the term appears, so that users can see the broad relevance of that term and go to and read those sections also. The search will also provide links to any references in the definition of the term that are available on PubMed and provide full references for books/chapters or other referenced articles that are not on PubMed. This compares to the current version, where hyperlinks usefully take readers to the main definition of any term (from anywhere that it appears in the Dictionary) but does not cross references all uses of the term.

2. The online version will support continuous edits, updates and comments (without users having to wait for the next annual update in August). All such edits and entries will be dated and linked to the person making them and their institution. The tool will allow discussion of existing terms and definitions and of corrections and edits in an open and transparent way. The tool will request that those making edits and new entries indicate whether they would like to join the lead author group. Those who request this will be expected to make an appropriate contribution to the next (and subsequent) annual update(s) of the Dictionary and its online tool. Annual reviews in August will continue and, at each of these, a new 'clean' version of the online MR Dictionary will be announced, with previous versions (including edits and discussions) archived. 

and relevance of the Dictionary. In the mean-time (i.e., up to August 2020 and the launch of the interactive tool), if you

112 think key terms are missing or you notice errors/inconsistencies in what we have written in 113 this initial version, then please let us know by emailing mr-dictionary@bristol.ac.uk, such that 114 we can include relevant suggestions in the next version with an appropriate acknowledgement. 


\section{Chapter 1: Useful genetic terms}

\begin{tabular}{|c|c|c|c|}
\hline Term & Brief definition & Relevance to MR & $\begin{array}{l}\text { Useful journal reference(s) } \\
\text { or references to figures } \\
\text { shown later in the chapter, } \\
\text { if appropriate }\end{array}$ \\
\hline Allele & $\begin{array}{l}\text { A variant form of a single nucleotide polymorphism } \\
\text { (SNP), a specific polymorphic site or a whole gene } \\
\text { detectable at a locus. Most SNPs are biallelic, } \\
\text { meaning that there are two values (forms) that are } \\
\text { possible (e.g., the rs } 234 \text { SNP denotes that individuals } \\
\text { could have either an A or G allele at position } \\
105,920,689 \text { on chromosome } 7 \text { on the positive } \\
\text { strand). At a given } S N P \text {, the most common allele is } \\
\text { referred to as the 'major allele'; whereas, the least } \\
\text { common (or rarer) allele is referred to as the 'minor } \\
\text { allele'. The minor allele frequency is therefore the } \\
\text { frequency at which the minor allele occurs within a } \\
\text { population. }\end{array}$ & $\begin{array}{l}\text { In } M R \text {, most commonly, the genetic } \\
\text { instrumental variable (IV) is one or more } \\
S N P(\mathrm{~s}) \text { that are robustly associated with } \\
\text { the risk factor/exposure of interest. The } \\
\text { number of 'trait-increasing' alleles is } \\
\text { used analogously to the lifetime 'dose' of } \\
\text { the risk factor. The commonest unit of } \\
\text { the genetic } I V \text {-risk factor or genetic } I V \text { - } \\
\text { outcome associations are 'per-allele' - } \\
\text { i.e., assuming a linear additive change } \\
\text { across the three genotype categories. See } \\
D N A \text { below. }\end{array}$ & $\begin{array}{l}(34) \\
\text { Figure } 1.1\end{array}$ \\
\hline
\end{tabular}




\begin{tabular}{|c|c|c|c|}
\hline Chromosome & $\begin{array}{l}\text { A deoxyribonucleic acid (DNA) molecule that carries } \\
\text { a portion of all genetic material. Two homologous } \\
\text { chromosomes carry the same collection of gene, but } \\
\text { each gene can be represented by a different allele on } \\
\text { the two homologues (a heterozygous individual). A } \\
\text { gamete (egg or sperm) will receive one of these } \\
\text { homologues, but not both. Humans have } 22 \text { pairs of } \\
\text { autosomal homologous chromosomes and } 1 \text { pair of } \\
\text { sex chromosomes. }\end{array}$ & $\begin{array}{l}\text { Used to identify the position of a genetic } \\
\text { variant within } M R \text { studies. }\end{array}$ & $\begin{array}{l}(34) \\
\text { Figure } 1.1\end{array}$ \\
\hline $\begin{array}{l}\text { Copy number variation } \\
\text { (CNV) }\end{array}$ & $\begin{array}{l}\text { Relatively large sections of the } D N A \text { are sometimes } \\
\text { deleted or repeated one or more times, such that in } \\
\text { those sections of } D N A \text {, the number of copies of the } \\
\text { section varies between individuals (rather than, for } \\
\text { example, a single } D N A \text { base differing between } \\
\text { individuals, as in } S N P S \text { ). }\end{array}$ & $\begin{array}{l}\text { So far, copy number variation has not } \\
\text { commonly been used in } M R \text { owing to a) } \\
\text { the majority of natural variation in } \\
\text { humans taking the form of } S N P s, 2 \text { ) } \\
\text { genotyping technology being principally } \\
\text { designed to assay SNPS and 3) a relative } \\
\text { paucity of robustly associated copy } \\
\text { number variants with phenotypes of } \\
\text { interest. }\end{array}$ & $(35,36)$ \\
\hline
\end{tabular}




\begin{tabular}{|c|c|c|c|}
\hline $\begin{array}{l}\text { Deoxyribonucleic acid } \\
\text { (DNA) }\end{array}$ & $\begin{array}{l}\text { DNA is a molecule that contains the genetic } \\
\text { instructions used in the development and } \\
\text { functioning of all living organisms. The main role of } \\
\text { DNA is the long-term storage of information. It } \\
\text { contains the template needed to construct other } \\
\text { components of cells, including ribonucleic acid } \\
\text { (RNA) and protein molecules, as well as regulatory } \\
\text { mechanisms. DNA has four nucleotide bases: } \\
\text { Adenine (A), Thymine (T), Guanine (G) and Cytosine } \\
\text { (C). The two strands of DNA in the double-helix } \\
\text { structure are complementary (sense and anti-sense } \\
\text { strands) such that A binds with T and G binds with C. }\end{array}$ & $\begin{array}{l}\text { Natural variation in DNA sequences is } \\
\text { assayed and tested for association with } \\
\text { phenotypes. Variants (most commonly } \\
\text { SNPs) are used as IVs. DNA has a double } \\
\text { helix structure, formed of two linked } \\
\text { strands of nucleotides that run in } \\
\text { opposite directions - either from the five- } \\
\text { prime (5') to the three-prime (3') (also } \\
\text { known as sense or forward/positive } \\
\text { direction) or from 3' to 5' (also known as } \\
\text { anti-sense or reverse), as shown in } \\
\text { Figure 1.1. The importance of this to } M R \\
\text { is in relation to harmonizing alleles } \\
\text { encoded differently (on either forward or } \\
\text { reverse strand) in different studies for } \\
\text { two-sample MR with summary } \\
\text { (aggregate) data. }\end{array}$ & $\begin{array}{l}(34) \\
\text { Figure } 1.1\end{array}$ \\
\hline
\end{tabular}




\begin{tabular}{|c|c|c|c|}
\hline Gene & $\begin{array}{l}\text { A gene comprises a } D N A \text { sequence, including introns, } \\
\text { exons and regulatory regions, related to } \\
\text { transcription of a given RNA. They provide the } \\
\text { template for production of a specific protein. }\end{array}$ & $\begin{array}{l}\text { Some genetic variants that are used in } \\
M R \text { are within the coding region of a } \\
\text { known gene. When } M R \text { is used to test the } \\
\text { effect of a product of a known gene (e.g., } \\
\text { adiponectin or C-reactive protein) on an } \\
\text { outcome, variants in the genes coding } \\
\text { that protein are used as IVs. Bias due to } \\
\text { horizontal pleiotropy is less likely than } \\
\text { with variants whose function is unknown } \\
\text { or where the risk factor being tested is } \\
\text { complex and not a direct gene product } \\
\text { (e.g., body mass index [BMI]). }\end{array}$ & (34) \\
\hline Genetic variant & $\begin{array}{l}\text { A position in the } D N A \text { sequence at which there are at } \\
\text { least two forms in the population. A genetic variant } \\
\text { that is within a region of the genome that codes for a } \\
\text { protein (i.e., is in an exon), can be categorised as } \\
\text { either synonymous (i.e., both forms code for the } \\
\text { same amino acid and the form that might be }\end{array}$ & $\begin{array}{l}\text { The genetic variants used as } I V S \text { in } M R \\
\text { studies are usually SNPs. However, the } \\
\text { term "genetic variant" can refer to other } \\
\text { variations within the genome (e.g., } \\
\text { chromosome abnormalities, copy number } \\
\text { variation, insertions/deletions or other }\end{array}$ & $(34,36)$ \\
\hline
\end{tabular}




\begin{tabular}{|c|c|c|c|}
\hline & $\begin{array}{l}\text { considered a mutation has no downstream effect on } \\
\text { the protein structure that is synthesized) or non- } \\
\text { synonymous (i.e., one form (the mutation form) } \\
\text { changes the amino acid and protein structure). } \\
\text { Synonymous variants can still have robust } \\
\text { associations with phenotypes through gene } \\
\text { regulation. }\end{array}$ & $\begin{array}{l}\text { sequence variations). Whilst most } \\
\text { genetic variants occur outside coding } \\
\text { regions, these are completely valid for } \\
M R \text { analyses, even though their function } \\
\text { or how they influence the exposure of } \\
\text { interest is unknown. }\end{array}$ & \\
\hline Genotype & $\begin{array}{l}\text { The genotype of an individual refers to the allele } \\
\text { inherited at a specific locus - if the alleles are the } \\
\text { same, the genotype is homozygous and, if different, } \\
\text { heterozygous. Because humans are diploid (i.e., we } \\
\text { inherit two pairs of chromosomes, one from each } \\
\text { parent), study participants can be categorised into } \\
\text { one of three genotype groups - homozygous for the } \\
\text { 'reference' allele (homozygotes), heterozygous } \\
\text { (heterozygotes - i.e., having one of each of the } \\
\text { 'reference' and 'non-reference' allele) and } \\
\text { homozygous for the 'non-reference' allele - usually }\end{array}$ & See Allele above. & $\begin{array}{l}(34) \\
\text { Figure } 1.1\end{array}$ \\
\hline
\end{tabular}




\begin{tabular}{|c|c|c|c|}
\hline & $\begin{array}{l}\text { coded } 0,1 \text { and } 2 \text {, for possible genotypes. A genotype } \\
\text { is usually denoted with two letters representing the } \\
\text { two nucleotide bases on the forward DNA strand at } \\
\text { that locus (i.e., for the rs } 234 \text { SNP that has two } \\
\text { common alleles A and G, AA, AG or GG would denote } \\
\text { three possible genotype combinations, representing } \\
\text { a homozygote for the A allele, a heterozygote and a } \\
\text { homozygote for the G allele, respectively). Genotypes } \\
\text { are often encoded in 'additive' or 'dosage' format, } \\
\text { which represent the count of the non-reference } \\
\text { allele, where AA = } 0 \text {, AG = } 1 \text { and GG = } 2 \text {. }\end{array}$ & & \\
\hline Haplotype & $\begin{array}{l}\text { A haplotype is a version of a section of a } \\
\text { chromosome. It describes the particular sequence of } \\
\text { alleles of linked genetic variants found on a single } \\
\text { chromosome. }\end{array}$ & $\begin{array}{l}\text { Whilst SNPS are most commonly used in } \\
M R \text {, haplotypes have also been used in } \\
\text { one-sample MR. }\end{array}$ & $(34,37,38)$ \\
\hline Heterozygous/heterozygote & $\begin{array}{l}\text { Where the alleles at a particular genetic locus are } \\
\text { different (i.e., the AG genotype stated in the examples } \\
\text { for genotype and allele). }\end{array}$ & See Allele above. & $(34)$ \\
\hline
\end{tabular}




\begin{tabular}{|c|c|c|c|}
\hline Homozygous/homozygote & $\begin{array}{l}\text { Where the alleles at a particular genetic locus are the } \\
\text { same (i.e., either the AA or GG genotype stated in the } \\
\text { examples for genotype and allele). }\end{array}$ & See Allele above. & (34) \\
\hline $\begin{array}{l}\text { Linkage disequilibrium } \\
\text { (LD), also known as gametic } \\
\text { phase disequilibrium }\end{array}$ & $\begin{array}{l}\text { LD is the non-random occurrence of genetic variants } \\
\text { in the population, produced due to the chromosomal } \\
\text { sections of genetic material inherited, such that } \\
\text { alleles for genetic variants close together are always } \\
\text { co-inherited unless randomly segregated by } \\
\text { recombination. This induces correlation between } \\
\text { genetic variants because the allele of one locus is } \\
\text { disproportionately co-inherited with an allele at } \\
\text { another locus. LD is typically high amongst variants } \\
\text { close together on the same chromosome, but long- } \\
\text { range LD including across multiple chromosome can } \\
\text { be induced due to various population processes. The } \\
\text { term LD describes a state that represents a } \\
\text { departure from the hypothetical situation in which }\end{array}$ & $\begin{array}{l}\text { In } M R \text {, the use of multiple IVs is akin to } \\
\text { aggregating information from multiple } \\
\text { independent trials. Therefore, ideally } \\
\text { independent genetic IVs are used as to } \\
\text { not 'double-count' the contribution of } \\
\text { any particular variants, which would lead } \\
\text { to under-estimation of the standard } \\
\text { error of the estimate. This is done by } \\
\text { either } 1 \text { ) clumping, whereby only a } S N P \\
\text { is retained per locus based on LD within } \\
\text { that population (or by using a } \\
\text { representative reference panel); or } 2 \text { ) } \\
\text { the estimation procedure is performed } \\
\text { conditional on the LD matrix between } \\
\text { genetic variants. }\end{array}$ & (34) \\
\hline
\end{tabular}




\begin{tabular}{|c|c|c|c|}
\hline & $\begin{array}{l}\text { all loci exhibit complete independence (linkage } \\
\text { equilibrium, LE). }\end{array}$ & & \\
\hline Locus & $\begin{array}{l}\text { A locus is a section of } D N A \text { sequence and can be a } \\
S N P \text {, a gene or a larger region of } D N A \text { sequence. }\end{array}$ & See Chromosome above. & $\begin{array}{l}(34) \\
\text { Figure } 1.1\end{array}$ \\
\hline Palindromic SNP & $\begin{array}{l}\text { A sequence of } D N A \text { is a palindrome if the 5' to } 3^{\prime} \\
\text { (sense or forward) sequence is the same as the } 3 \text { ' to } \\
5 \text { ' (antisense or reverse). For example, the sequence } \\
\text { ACCTAG (reading 5' to } 3 \text { ') is a palindrome because } \\
\text { its complement ( } 3 \text { ' to 5') is GATCCA. A palindromic } \\
S N P \text { (also known as an 'ambiguous' } S N P \text { ) is a } S N P \text { in } \\
\text { which the possible alleles for that SNP pair with each } \\
\text { other in the double helix structure. When this } \\
\text { occurs, alleles on the forward strand are the same as } \\
\text { on the reverse strand (e.g., C/G on forward is G/C on } \\
\text { the reverse, as shown in Figure } 1.1 \text { ). }\end{array}$ & $\begin{array}{l}\text { In two-sample MR with summary } \\
\text { (aggregate) data, it can be difficult to } \\
\text { harmonize palindromic SNPs if it is } \\
\text { unclear which way (5' to } 3^{\prime} \text { ' or vice versa) } \\
\text { the alleles are presented in each genome- } \\
\text { wide association studies (GWAS). For } \\
\text { some palindromes, it is possible to infer } \\
\text { which is the effect allele using the allele } \\
\text { frequency information. Where this is not } \\
\text { the case, the options are to (i) assume all } \\
\text { SNPS in both GWASs have been presented } \\
\text { in the 5' to 3' way based on knowledge of } \\
\text { other SNPs that are non-palindromic or }\end{array}$ & $\begin{array}{l}39) \\
\text { Figure } 1.1\end{array}$ \\
\hline
\end{tabular}




\begin{tabular}{|c|c|c|c|}
\hline & & $\begin{array}{l}\text { (ii) drop all palindromic } S N P S \text { for which it } \\
\text { is not possible to infer the direction. }\end{array}$ & \\
\hline $\begin{array}{l}\text { Polygenic risk score (PGRS), } \\
\text { also known as a genetic risk } \\
\text { score, allele score, risk } \\
\text { score, genetic score, genetic } \\
\text { values, breeding values }\end{array}$ & $\begin{array}{l}\text { A single variable that is produced by aggregating } \\
\text { information from several SNPs that associate with a } \\
\text { trait/phenotype and that can be used in prediction } \\
\text { or causal analyses (i.e., MR). Usually, genetic risk } \\
\text { scores tend to comprise SNPs that have been } \\
\text { identified in GWASs at a genome-wide significance p- } \\
\text { value threshold to include } S N P S \text { that are most } \\
\text { robustly associated with a particular trait. PGRSs are } \\
\text { increasingly being used and tend to include genetic } \\
\text { information on the whole genome (or a much less } \\
\text { stringent threshold of inclusion). In an unweighted } \\
\text { PGRS, the number of 'effect' alleles each person in a } \\
\text { study has are simply added together. For example, if } \\
\text { a score was composed from } 5 S N P s \text { for a trait and an } \\
\text { individual had genotypes of } 0,1,1,2 \text { and } 0 \text {, referring } \\
\text { to the number of trait increasing alleles, their score }\end{array}$ & $\begin{array}{l}\text { PGRSs have commonly been used in one- } \\
\text { sample } M R \text {. They can also be generated } \\
\text { and used in two-sample } M R \text {. In } \\
\text { comparison to using each genetic variant } \\
\text { as a separate } I V \text {, combining them into a } \\
\text { single } I V \text { can increase statistical power } \\
\text { but if some of the variants contributing } \\
\text { to the score are invalid (i.e., violate } I V \\
\text { assumptions) results are likely to be } \\
\text { biased. }\end{array}$ & $(40,41)$ \\
\hline
\end{tabular}




\begin{tabular}{|c|c|c|c|}
\hline & $\begin{array}{l}\text { would be } 4 \text {. Weighted scores multiply the number of } \\
\text { 'effect' alleles by the magnitude (usually the beta) of } \\
\text { the GWAS association value for each } S N P \text {. In the } \\
\text { above example, if the differences in mean level of the } \\
\text { trait per allele for each of the } 5 S N P S \text { were } 0.5,1.0 \text {, } \\
0.5,2.0 \text { and } 0.6 \text {, respectively, then the weighted } \\
\text { score for the same individual would be } 0 \times 0.5+1 \times 1.0 \\
+1 \times 0.5+2 \times 2.0+0 \times 0.6=5.5 \text {. Weighted scores are } \\
\text { also known as weighted allele sores (WAS). }\end{array}$ & & \\
\hline Polymorphism & $\begin{array}{l}\text { A polymorphism is a genetic variant. The term is } \\
\text { usually limited to variants that are moderately } \\
\text { common (it is unusual for the term to be used when } \\
\text { referring to rare variants). }\end{array}$ & $\begin{array}{l}\text { Moderately common genetic variants } \\
\text { tend to have modest effects on traits; } \\
\text { therefore, the variance explained in that } \\
\text { trait by common polymorphisms } \\
\text { (including } S N P s \text { ) is relatively small. Thus, } \\
\text { MR studies using a small number of } \\
\text { moderately common polymorphisms will } \\
\text { require large sample sizes or the } \\
\text { combination of many polymorphisms/ }\end{array}$ & (34) \\
\hline
\end{tabular}




\begin{tabular}{|c|c|c|c|}
\hline & & $\begin{array}{l}\text { genetic variants (within a polygenic risk } \\
\text { score (PGRS)) for adequate statistical } \\
\text { power. }\end{array}$ & \\
\hline Rare variants & $\begin{array}{l}\text { Rare variants occur at low frequencies (usually } \\
\text { defined as a genetic variant for which the rare allele } \\
\text { occurs in }<1 \% \text { of a population). The majority of } \\
\text { genetic variants analysed in GWAS are common SNPs } \\
\text { due to the relative ease in assaying them. Improved } \\
\text { imputation methods, and reduced costs of } \\
\text { sequencing mean that more genetic associations will } \\
\text { be found for rare variants in the future. }\end{array}$ & $\begin{array}{l}\text { Statistical power to detect a genetic } \\
\text { association chiefly depends on the } \\
\text { sample size and the variance explained } \\
\text { by the genetic variant. While the majority } \\
\text { of genetic associations with common } \\
\text { variants have very small effects, rare } \\
\text { variants can only explain sufficiently } \\
\text { large variation for detection if they have } \\
\text { large effect sizes. The utility of rare } \\
\text { variants in } M R \text {, therefore, is that they } \\
\text { provide an opportunity to evaluate if the } \\
\text { causal effect estimate increases linearly } \\
\text { with larger intervention sizes. }\end{array}$ & $(42,43)$ \\
\hline $\begin{array}{l}\text { Single nucleotide } \\
\text { polymorphism (SNP) }\end{array}$ & $\begin{array}{l}\text { SNPs are genetic variants in which one base in the } \\
D N A \text { is altered, e.g., a G instead of an } \mathrm{A} \text { in the }\end{array}$ & See Allele and Genetic variant above. & $(34)$ \\
\hline
\end{tabular}




\begin{tabular}{|c|c|}
\hline & $\begin{array}{l}\text { example above (see Genotype above). The term } \\
\text { single nucleotide variant (SNV) is also widely used to } \\
\text { include both rare variants and common } \\
\text { polymorphisms. }\end{array}$ \\
\hline
\end{tabular}


Figure 1.1: Schematic representation of Chromosomes, DNA and genetic variants in a diploid cell. From Hartwig et al. (16), with permission.

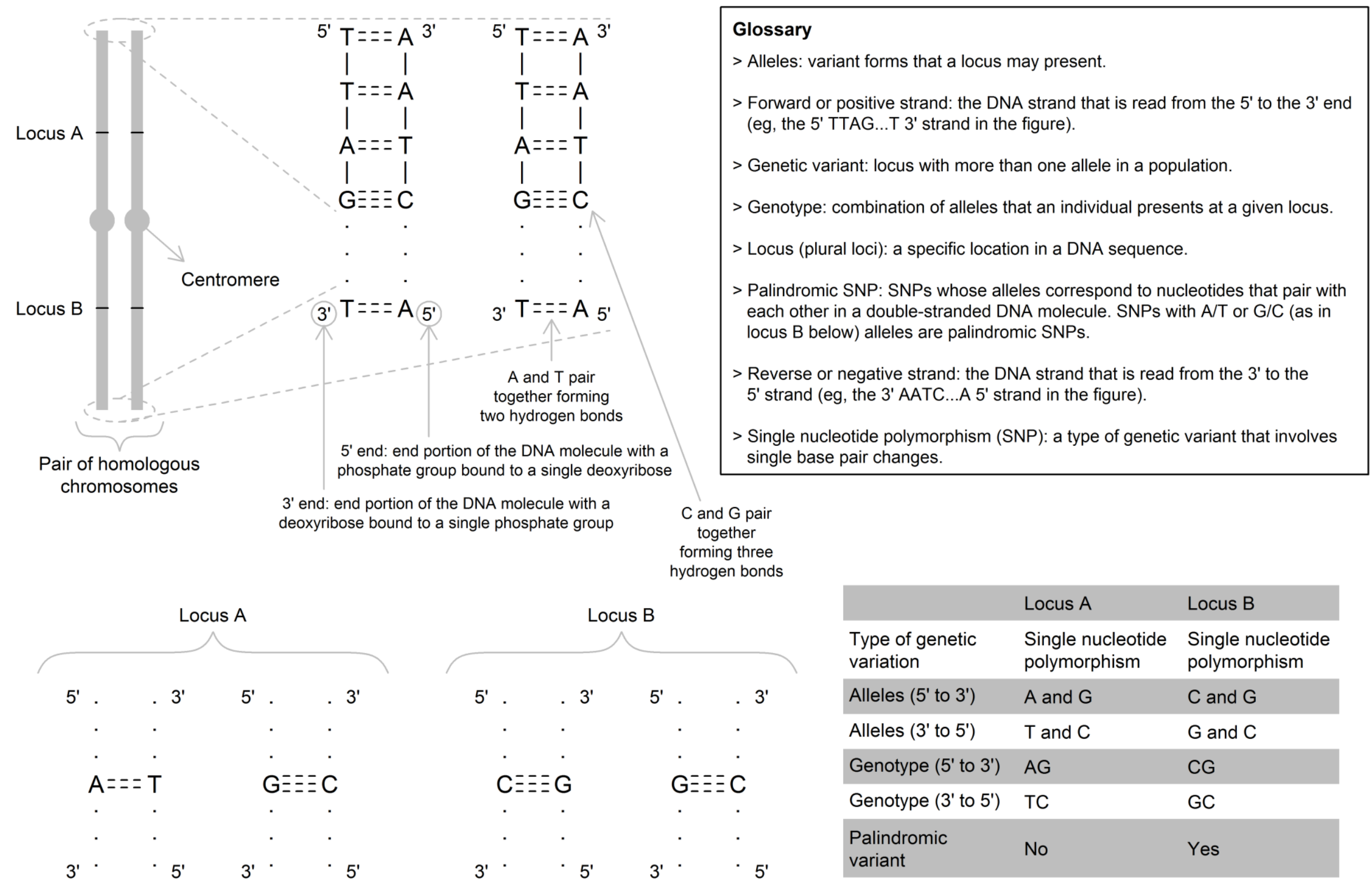




\section{Chapter 2: Definition and types of Mendelian randomization (MR)}

\begin{tabular}{|c|c|c|c|}
\hline Term & Brief definition & Summary assumptions / key sources of bias & $\begin{array}{l}\text { Useful journal } \\
\text { reference(s) or } \\
\text { references to } \\
\text { figures shown } \\
\text { later in the } \\
\text { chapter, if } \\
\text { appropriate }\end{array}$ \\
\hline Bidirectional MR & $\begin{array}{l}\text { An } M R \text { analysis that tries to differentiate whether } \\
\text { factor A is a cause or a consequence of factor B or } \\
\text { whether there is a true bidirectional causal effect } \\
\text { between A and B. }\end{array}$ & $\begin{array}{l}\text { Genetic variants for 'risk factor' A and 'outcome' B } \\
\text { need to fulfil the same assumptions as IVs. This } \\
\text { requires genetic variants for both variables (A and B) } \\
\text { to test each of the three possibilities: A causes B; B } \\
\text { causes A; there is a true bidirectional causal } \\
\text { relationship between A and B. In comparing results in } \\
\text { both directions, caution is required to take account of } \\
\text { differences in statistical power related to the } I V \text {-risk } \\
\text { factor association. }\end{array}$ & $\begin{array}{l}(44,45) \\
\text { Figure } 2.1\end{array}$ \\
\hline
\end{tabular}




\begin{tabular}{|c|c|c|c|}
\hline Binary exposure MR & $\begin{array}{l}\text { When } M R \text { is used to test the effect of a binary } \\
\text { exposure, such as hypertension, obesity, or insomnia, } \\
\text { results can also be difficult to interpret. At face value, } \\
\text { the effect estimate is a ratio of a ratio. Additional } \\
\text { considerations regarding violation of } I V \text { assumptions } \\
\text { may be required in comparison to continuous } \\
\text { exposures. }\end{array}$ & $\begin{array}{l}\text { The exclusion restriction assumption may be violated } \\
\text { by variation in the underlying or latent continuous } \\
\text { trait (e.g., blood pressure or BMI), which will vary } \\
\text { within the two categories (e.g., hypertensive versus } \\
\text { normotensive). In MR analyses (as with multivariable } \\
\text { analyses), one should consider whether dichotomising } \\
\text { underlying continuous variables is appropriate. Where } \\
\text { binary exposures are used, a cautious interpretation of } \\
\text { the 'genetic liability' to an exposure might be } \\
\text { warranted. Scaling the results, for example describing } \\
\text { the effect estimate as a risk ratio (of a binary outcome) } \\
\text { of difference in mean (continuous outcome) per } \\
\text { doubling of the liability to exposure has been } \\
\text { recommended. }\end{array}$ & $(46-48)$ \\
\hline Factorial MR & $\begin{array}{l}\text { An } M R \text { method that explores the separate and joint } \\
\text { causal effects of two (or potentially more) risk factors } \\
\text { on an outcome and is analogous to factorial } \\
\text { randomized controlled trial (RCT) designs. }\end{array}$ & $\begin{array}{l}\text { Genetic IVs for the two (or potentially more) risk } \\
\text { factors are the categories defined by genetic variants. } \\
\text { These categories need to fulfil the key IV assumptions. } \\
\text { Factorial MR may have limited statistical power (in }\end{array}$ & $\begin{array}{l}(22) \\
\text { Figure } 2.2\end{array}$ \\
\hline
\end{tabular}




\begin{tabular}{|c|c|c|c|}
\hline & $\begin{array}{l}\text { Participants in a factorial } M R \text { study are categorised } \\
\text { into different levels of each risk factor based on their } \\
\text { genetic IVs. Where the genetic IV involves multiple } \\
\text { SNPs, categories of high vs. low exposure might be } \\
\text { defined by being above and below the median of a } \\
\text { polygenic risk score (PGRS) of those SNPs. For a genetic } \\
\text { IV that includes a SNP, the categorisation will be one } \\
\text { group of homozygotes versus a group of the } \\
\text { heterozygotes and other homozygotes together, or } \\
\text { three groups of homozygotes for one allele, } \\
\text { heterozygotes, and homozygotes for the other allele. } \\
\text { Regression analyses are then conducted with the } \\
\text { genetic IV categories. }\end{array}$ & $\begin{array}{l}\text { comparison to factorial RCTs and } M R \text { of single risk } \\
\text { factors). }\end{array}$ & \\
\hline $\begin{array}{l}\text { Instrumental variable } \\
\text { (IV) }\end{array}$ & $\begin{array}{l}\text { An IV is a variable (characteristic) that is robustly } \\
\text { associated with the risk factor of interest and can be } \\
\text { used to explore the unconfounded causal effect of that } \\
\text { risk factor on an outcome, under the assumptions in } \\
\text { the next column. }\end{array}$ & $\begin{array}{l}\text { There are three core assumptions of IV analyses: } \\
\text { 1. The IV is robustly associated with the risk } \\
\text { factor of interest (i.e., replication of its } \\
\text { association has been demonstrated). In }\end{array}$ & $(30,49-52)$ \\
\hline
\end{tabular}




\begin{tabular}{|c|c|c|}
\hline A & 列 & $\begin{array}{l}\text { econometrics, this is known as the relevance } \\
\text { assumption. } \\
\text { 2. The IV is not associated with confounders of } \\
\text { the risk factor-outcome association. In } \\
\text { econometrics, this is known as the } \\
\text { independence or exchangeability assumption. } \\
\text { 3. The IV is only associated with the outcome } \\
\text { through the risk factor. In econometrics, this is } \\
\text { known as the exclusion restriction assumption. } \\
\text { Additional assumptions are required to identify a well- } \\
\text { defined causal parameter. These assumptions can be } \\
\text { grouped as follows: } \\
\text { Homogeneity assumptions: assuming either that } \\
\text { the association between the IV and the exposure is } \\
\text { homogeneous (i.e., is the same for everyone in the } \\
\text { population) or that the effect of the exposure on } \\
\text { the outcome is homogeneous. If true, this implies }\end{array}$ \\
\hline
\end{tabular}




\begin{tabular}{|c|c|c|}
\hline & 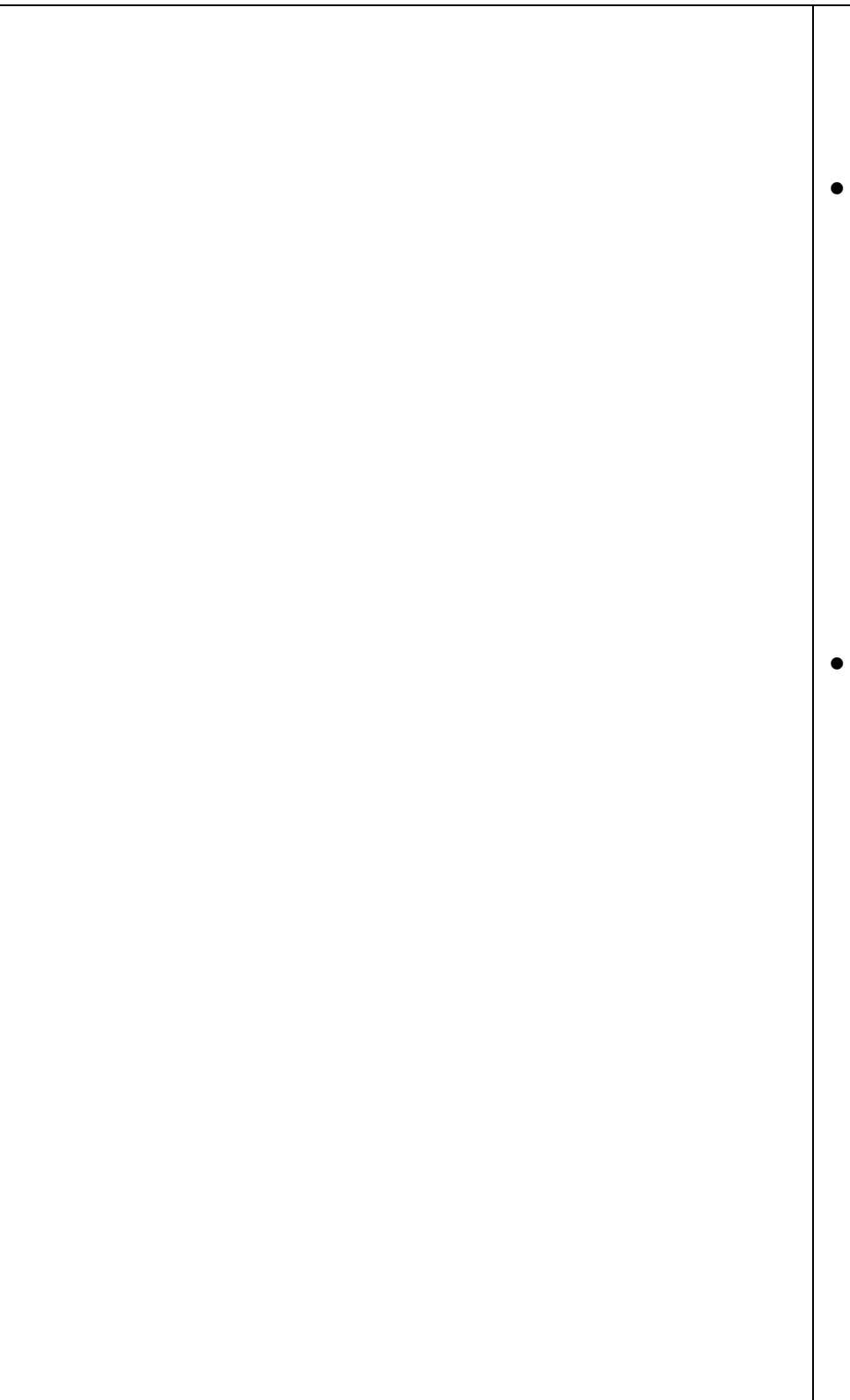 & $\begin{array}{l}\text { that the IV estimate is consistent with the average } \\
\text { causal effect (ACE). } \\
\text { No effect modification: if the IV does not modify the } \\
\text { effect of the exposure on the outcome within levels } \\
\text { of the exposure and for all levels of the exposure, } \\
\text { then the IV estimate is consistent with the ACE } \\
\text { even if the effect of the exposure on the outcome is } \\
\text { heterogeneous. } \\
\text { simply as "monotonicity", this assumes a } \\
\text { monotonic relationship between the IV and } \\
\text { exposure. In other words, a (genetic) IV could not } \\
\text { increase the exposure in some people and } \\
\text { decrease it in others. This allows the assumption } \\
\text { that the effect of the IV on the exposure is } \\
\text { homogeneous to be relaxed. If monotonicity holds, } \\
\text { then the IV estimate is consistent with the ACE }\end{array}$ \\
\hline
\end{tabular}




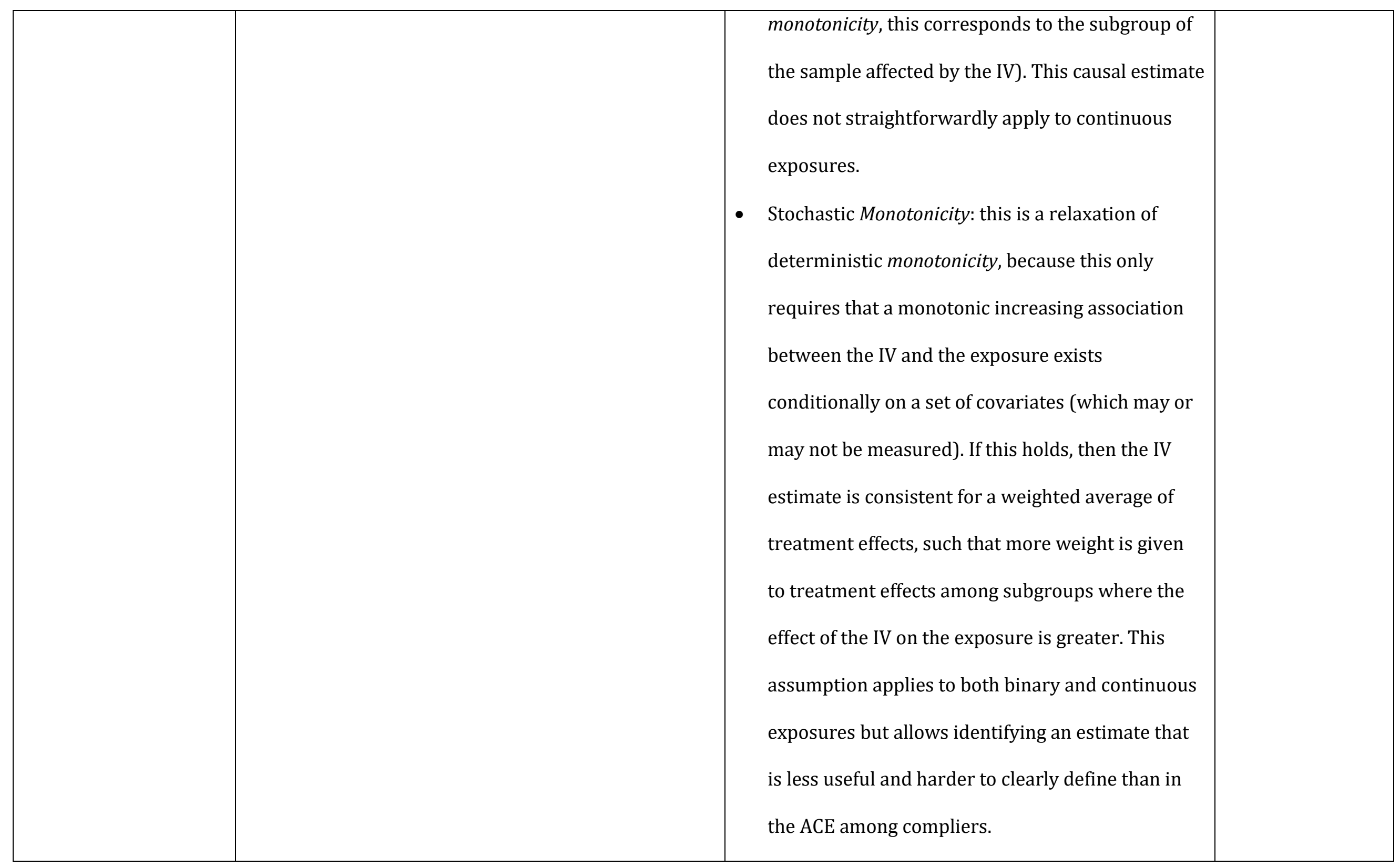




\begin{tabular}{|c|c|c|c|}
\hline $\begin{array}{l}\text { Mendelian } \\
\text { randomization (MR) }\end{array}$ & $\begin{array}{l}\text { A method that uses genetic variants as IVs to explore } \\
\text { causal effects of risk factors on outcomes in } \\
\text { observational epidemiological studies. }\end{array}$ & $\begin{array}{l}\text { Genetic IVs must fulfil the same assumptions as IVs. In } \\
\text { most MR studies, the assumption that is most likely to } \\
\text { be violated is the exclusion restriction assumption due } \\
\text { to horizontal pleiotropy. }\end{array}$ & $(1,30)$ \\
\hline Multivariable MR & $\begin{array}{l}M R \text { analyses in which genetic instruments for more } \\
\text { than one exposure are used. Multivariable MR can be } \\
\text { used to estimate mediating effects in two-step MR, to } \\
\text { adjust for possible pleiotropy (e.g., to isolate specific } \\
\text { lipid effects) bias due to horizontal pleiotropy of a } \\
\text { specific effect, or to adjust for potential confounding. }\end{array}$ & $\begin{array}{l}\text { All of the genetic instruments should fulfil the } I V \\
\text { assumptions. In addition, each instrument should be } \\
\text { associated with more than one of the exposures } \\
\text { included in the analyses; each instrument does not } \\
\text { need to be associated with all exposures but each one } \\
\text { does need to be associated with more than one } \\
\text { exposure. When using multivariable } M R \text { to adjust for } \\
\text { confounding or horizontal pleiotropy, it is important to } \\
\text { make sure that an exposure on the causal path } \\
\text { between the primary exposure of interest is not being } \\
\text { adjusted for. }\end{array}$ & $\begin{array}{l}(4,53,54) \\
\text { Figure } 2.3\end{array}$ \\
\hline One-sample MR & $\begin{array}{l}M R \text { analyses in which the genetic } I V \text {-risk factor } \\
\text { association and genetic } I V \text {-outcome association are } \\
\text { from the same sample. }\end{array}$ & $\begin{array}{l}\text { Genetic } I V s \text { must fulfil the same } I V \text { assumptions. The } \\
\text { gene-outcome model must be correctly specified, but } \\
\text { the gene-exposure model can be miss-specified. One- }\end{array}$ & Figure 2.4 \\
\hline
\end{tabular}




\begin{tabular}{|c|c|c|c|}
\hline & & $\begin{array}{l}\text { sample } M R \text { is more prone to data overfitting than two- } \\
\text { sample } M R \text {. Though, two-sample MR may be similar to } \\
\text { one-sample if there is overlap of participants in the } \\
\text { two samples. In one-sample } M R \text {, weak instrument bias } \\
\text { will tend to bias towards the confounded } \\
\text { multivariable regression estimate. }\end{array}$ & \\
\hline Two-sample MR & $\begin{array}{l}M R \text { analyses in which the genetic } I V \text {-risk factor } \\
\text { association and genetic } I V \text {-outcome association are } \\
\text { generated from different (non-overlapping) samples. } \\
\text { NOTE: there are 'grey areas' between one-sample and } \\
\text { two-sample } M R \text { (e.g., where two samples have some } \\
\text { overlap, as shown in Figure } 2.5 \text { ). }\end{array}$ & $\begin{array}{l}\text { Genetic IVs must fulfil the same IV assumptions. The } \\
\text { gene-exposure and gene-outcome models must be } \\
\text { correctly specified. In two-sample MR, weak } \\
\text { instrument bias will tend to bias towards the null. } \\
\text { Correct harmonization of alleles across the two } \\
\text { samples is essential. The two samples should be from } \\
\text { the same underlying population. The two samples } \\
\text { should be (largely) non-overlapping. }\end{array}$ & $\begin{array}{l}(17,45,55) \\
\text { Figure } 2.5, \\
\text { Figure } 2.6\end{array}$ \\
\hline $\begin{array}{l}\text { Two-sample MR with } \\
\text { individual participant } \\
\text { data (IPD) }\end{array}$ & $\begin{array}{l}\text { Two-sample } M R \text { in which IPD is available. } \\
\text { NOTE: some } M R \text { studies use a mixture of aggregate } \\
\text { and IPD (where the genetic } I V \text {-risk factor association }\end{array}$ & $\begin{array}{l}\text { Assumptions and key sources of bias are as for two- } \\
\text { sample MR. There is more potential (than with } \\
\text { aggregate data) for assessing the genetic } I V \text { association } \\
\text { with observed confounders of the risk factor-outcome }\end{array}$ & $\begin{array}{l}(17,45) \\
\text { Figure } 2.5, \\
\text { Figure } 2.6\end{array}$ \\
\hline
\end{tabular}




\begin{tabular}{|c|c|c|c|}
\hline & $\begin{array}{l}\text { may be from aggregate data and the genetic } I V- \\
\text { outcome association may be from IPD - or vice versa). }\end{array}$ & $\begin{array}{l}\text { association, exploring interactions or subgroup effects } \\
\text { and removing overlapping samples. }\end{array}$ & \\
\hline $\begin{array}{l}\text { Two-sample MR with } \\
\text { summary (aggregate) } \\
\text { data }\end{array}$ & $\begin{array}{l}\text { Two-sample MR in which summary (aggregate) results } \\
\text { are used for the genetic } I V \text {-risk factor and genetic } I V \text { - } \\
\text { outcome associations. These are usually summary } \\
\text { statistics from GWASs that are publicly available. }\end{array}$ & $\begin{array}{l}\text { Assumptions and key sources of bias are as for two- } \\
\text { sample MR. With aggregate data, it may be difficult to } \\
\text { ensure the two samples are from the same underlying } \\
\text { population. It is difficult to explore whether the genetic } \\
\text { IVs are related to confounders of the risk factor- } \\
\text { outcome association. It is not possible to detect non- } \\
\text { linear effects unless there are aggregate data results } \\
\text { for non-linear effects. Where the two samples overlap, } \\
\text { the greater the overlap, the more the study properties } \\
\text { become like one-sample MR. }\end{array}$ & $\begin{array}{l}(17,39) \\
\text { Figure } 2.5, \\
\text { Figure } 2.6\end{array}$ \\
\hline $\begin{array}{l}\text { Two-step/Mediation } \\
\text { MR }\end{array}$ & $\begin{array}{l}\text { An } M R \text { framework that aims to quantify whether a risk } \\
\text { factor-outcome association (that is either established } \\
\text { or has supportive evidence from } M R \text { analyses) is } \\
\text { mediated by another risk factor. In many published } \\
\text { examples, initial } M R \text { will assess evidence for a causal }\end{array}$ & $\begin{array}{l}\text { The } I V \text { assumptions must be met for the two steps of } \\
\text { the } M R \text { analyses of the (i) risk factor on mediator and } \\
\text { (ii) mediator on outcome. This methodology can be } \\
\text { extended to networks of relationships (i.e., network } \\
M R \text { ). }\end{array}$ & $\begin{array}{l}(4,24,25,56) \\
\text { Figure } 2.7\end{array}$ \\
\hline
\end{tabular}


effect of the risk factor on an outcome and then go on

to undertake two-step $M R$. First, genetic IVs

associated with the risk factor are used to determine

the causal effect of the risk factor on the potential

mediator (step one). Secondly, genetic IVs associated

with the potential mediator and independent of those

used for step one are used to determine the effect of

the potential mediator on the outcome of interest

(step two). Where evidence is found for a causal effect

of a risk factor on an outcome, a risk factor on a

mediator and a mediator on an outcome, methods

such as multivariable $M R$ or product-of-coefficients

can be used to explore the extent of this mediation. 
Figure 2.1: Bidirectional Mendelian randomization. Adapted from Richmond et al. (44).

(A)

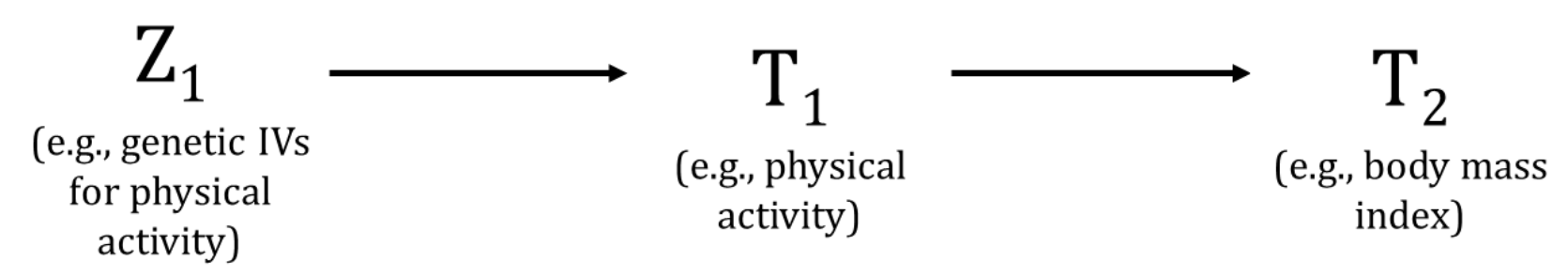

(B)

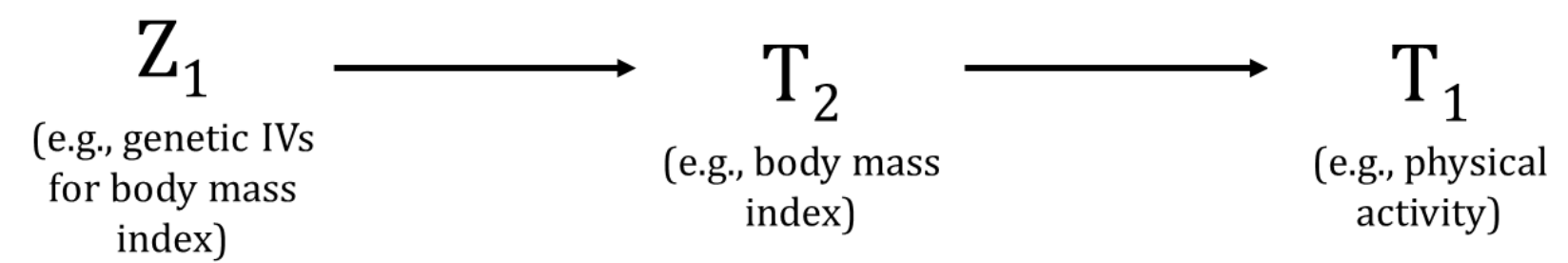

Bidirectional MR involves exploring both possible directions of effect between two traits (e.g., between body mass index and physical activity) by undertaking two separate MR analyses (shown in (A) and (B)). In figure (A), a genetic instrument $\left(Z_{1}\right)$ is used to assess the causal effect of the first trait ( $T_{1}$, physical activity) on the second trait ( $T_{2}$, body mass index). In figure (B), an independent genetic instrument $\left(Z_{2}\right)$ is used to assess the reverse effect - i.e., a possible causal effect of body mass index on physical activity. 
Figure 2.2: Factorial MR Mendelian randomization Adapted with permission from Carter et al. (23).

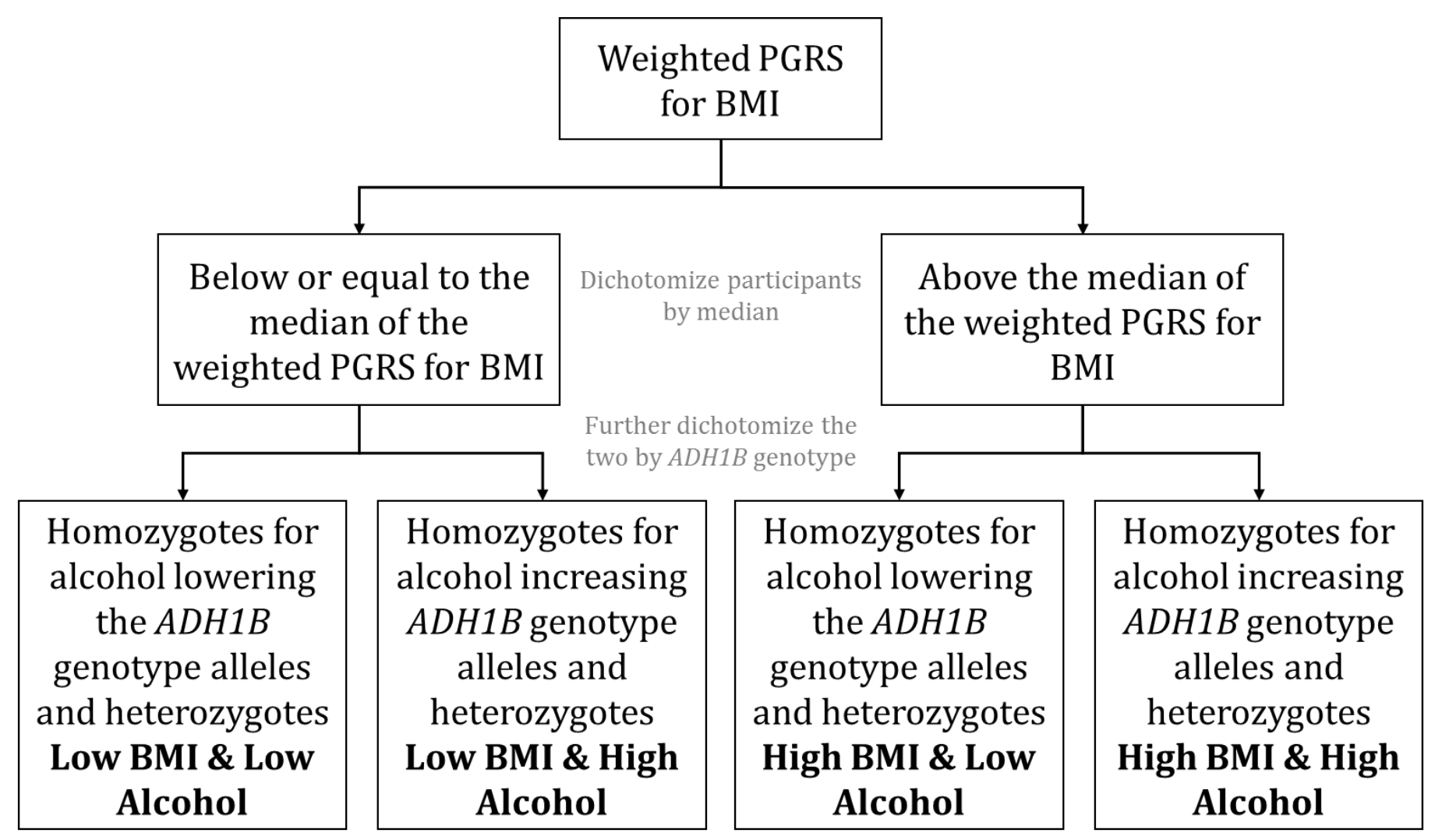

In this example, Factorial MR is used to investigate the combined effects of BMI and alcohol on liver disease and liver disease biomarkers. Disease and biomarker levels are compared across the four categories of genetically instrumented combinations of low and high BMI and alcohol levels. Low and high BMI were defined as below or equal to and above the median of a weighted polygenic risk score (PGRS) for BMI, respectively. For low and high alcohol categories, a single candidate genetic instrumental variable (ADH1B) was used as an instrument and homozygotes for the allele associated with higher alcohol consumption (high) were compared to those who were heterozygotes or homozygotes for the allele associated with lower alcohol consumption. 
Figure 2.3: Multivariable Mendelian randomization. Adapted from Zheng et al. (32).

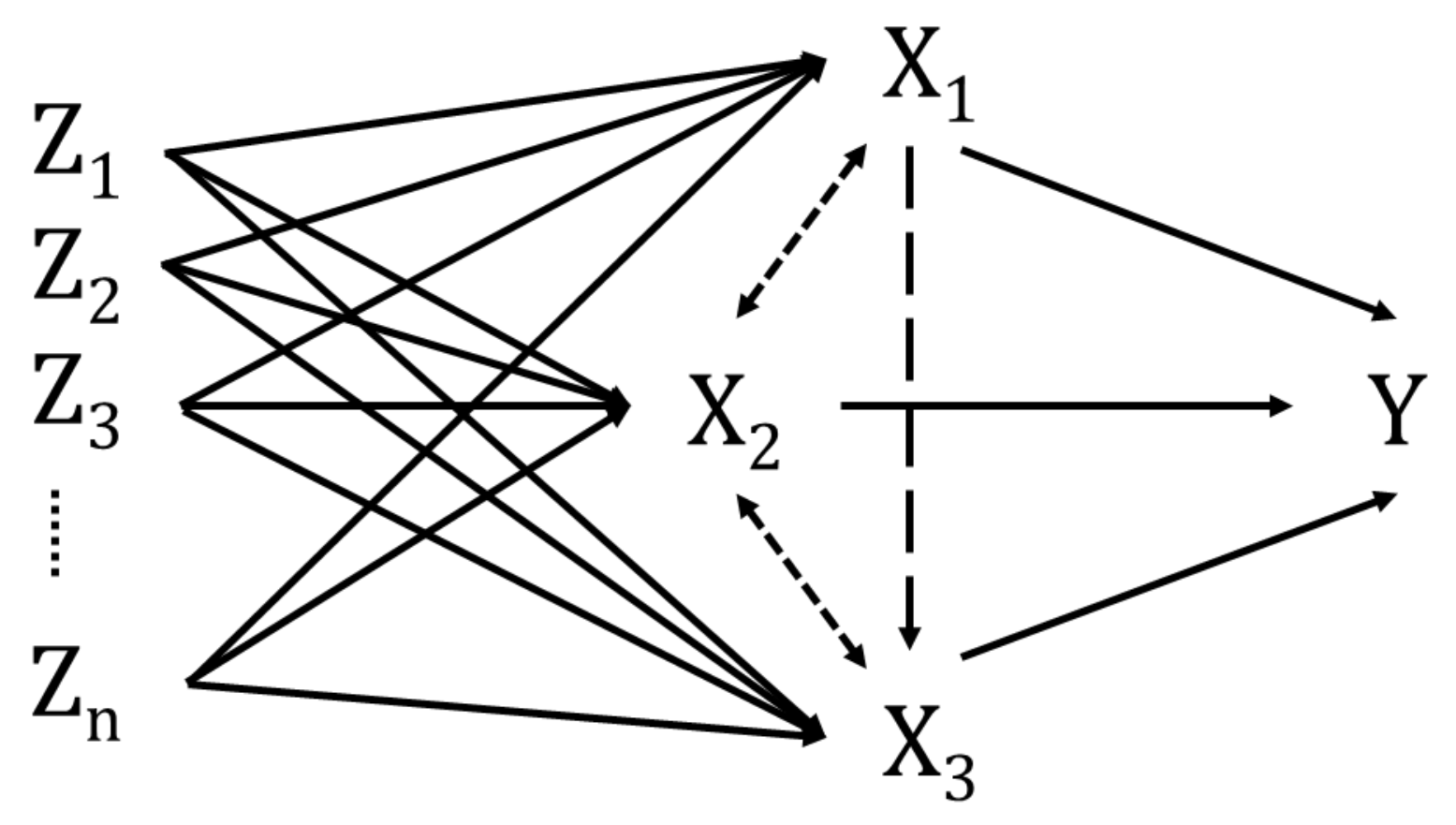

Multivariable MR uses multiple instruments $\left(Z_{1}, \ldots, Z_{n}\right)$ associated with multiple, potentially correlated exposures (e.g., $X_{1}, X_{2}$ and $\left.X_{3}\right)$ to jointly estimate the independent causal effect of each of the exposures on a particular outcome (Y). It can also be used to explore mediation following two-step MR. 


\section{Figure 2.4: One-sample Mendelian randomization}

(A)

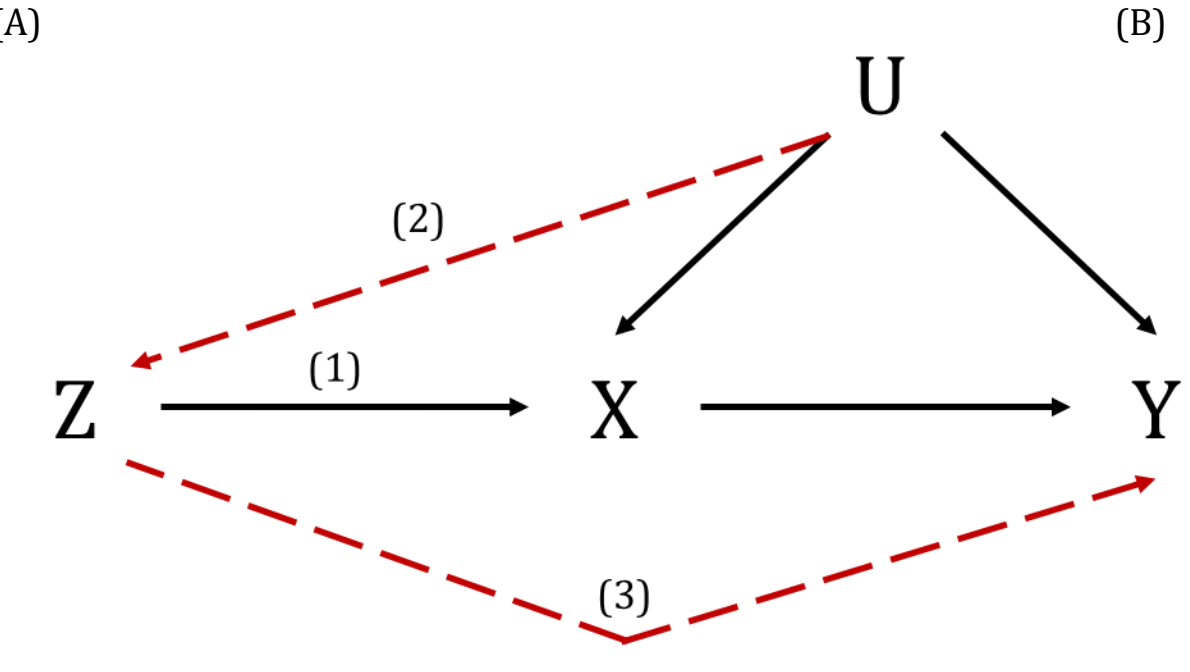

(B)

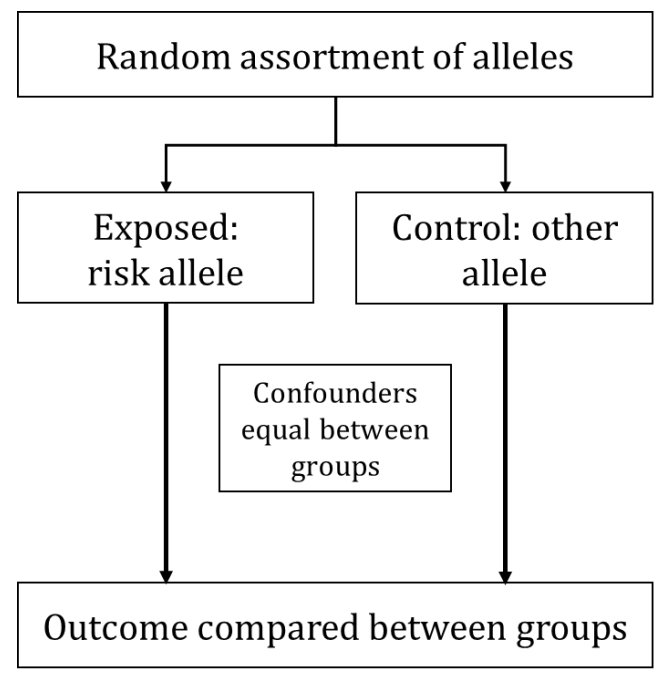

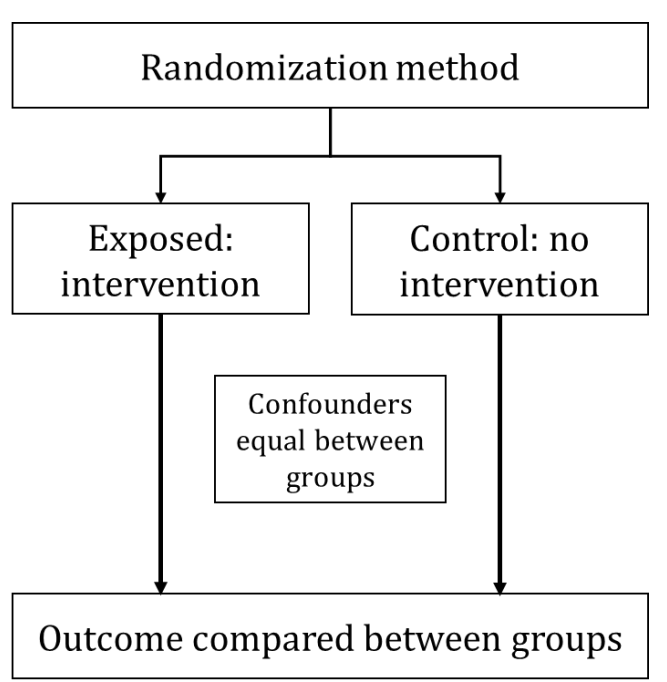

(C) $\beta_{I V}=\beta_{Y Z} / \beta_{X Z}$

(A) MR relies on the following three core assumptions (see Chapter 2 for other assumptions): (1) the genetic variant(s) being used as an instrument (Z) is associated with the exposure (X); (2) the instrument in independent of measured and unmeasured confounders ( $U$ ) of the association between the exposure (X) and outcome (Y); and (3) there is no independent pathway between the instrument $(Z)$ and outcome $(Y)$ other than through the exposure $(X)$ - otherwise known as horizontal pleiotropy or the exclusion restriction assumption (see Chapter 4 for definition). (B) MR can be perceived as being analogous to a randomized controlled trial (RCT), whereby the random assortment of alleles at conception is equivalent to the randomization method with an RCT. This randomization process produces groups of individuals who differ with respect to the intervention (in the case of MR, genetic variation) and between which confounders are equally distributed. Therefore, any differences observed in the outcome of interest between these randomly allocated groups should be due to the exposure with which the genetic variant(s) are associated. (C) In the most simple of scenarios, the causal estimate of the association between the exposure $(X)$ and outcome $(Y)$ can be derived using the instrumental variable ratio method (otherwise known as the Wald ratio), where $\beta_{I V}$ is the causal estimate derived from instrumental variable (i.e., MR) analyses, $\beta_{Y Z}$ is the association between the instrument (Z) and the outcome $(Y)$ and $\beta_{X Z}$ is the association between the instrument $(Z)$ and the exposure $(X)$ - see Chapter 5 - Chapter 8 for the variety of methods used to derive causal estimates. 
Figure 2.5: Two-sample Mendelian randomization. Adapted from Hemani et al. (39)

(A)

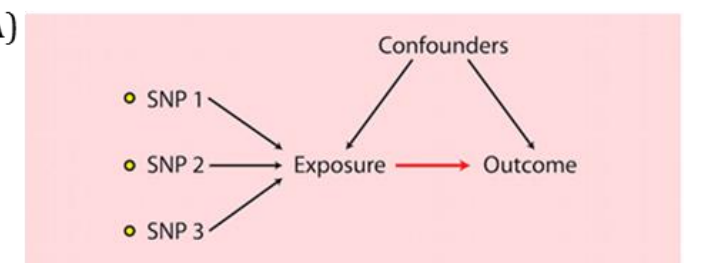

(B)

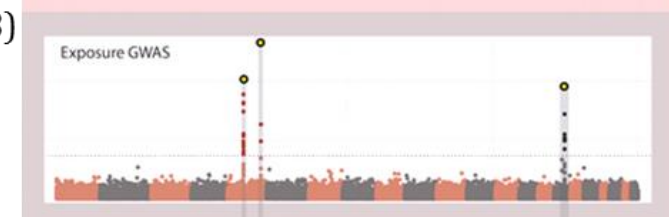

(C)

(D)
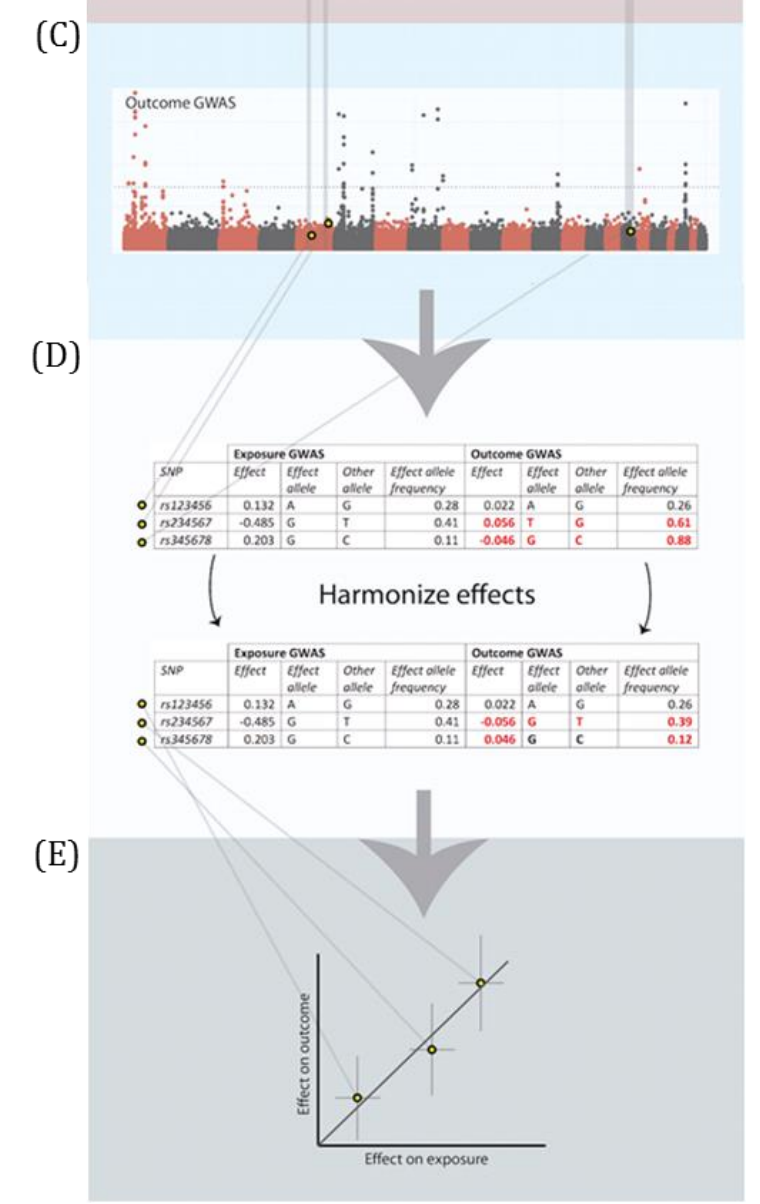

(A) In two-sample MR, the associations of the instrument(s) with the exposure and outcome are derived from two independent (i.e., non-overlapping) samples. In this example, there are three SNPs acting as genetic IVs for the hypothetical exposure (i.e., SNP1, SNP2 and SNP3). (B) Manhattan plots showing the SNP-exposure estimates for each of the three SNPs are derived from a genome-wide association studies (GWAS) of the exposure variable. (C) The estimates of association between these three same SNPs and the outcome variable are then obtained from the outcome GWAS (results that are also depicted in a Manhattan plot). (D) Effects are harmonized to ensure that the 'effect' estimates in both the exposure and outcome GWASs correspond to the same allele (i.e., one that consistently either increases or decreases the exposure variable) for each SNP. (E) Once effects are harmonized, MR analyses can be performed. Visually, a scatter plot can be generated to represent the results, whereby the slope of the line is equivalent to the causal estimate. For example, the when using the inverse-variance weighted method, the intercept is held at zero (see Chapter 8 for two-sample methodology). 
Figure 2.6: Relationship of one- and two-sample Mendelian randomization: populations and samples

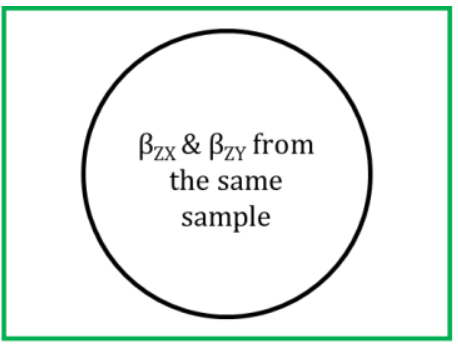

(A) One-sample MR

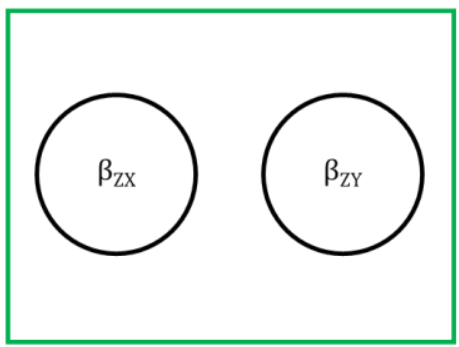

(D) Two-sample MR (ideal)

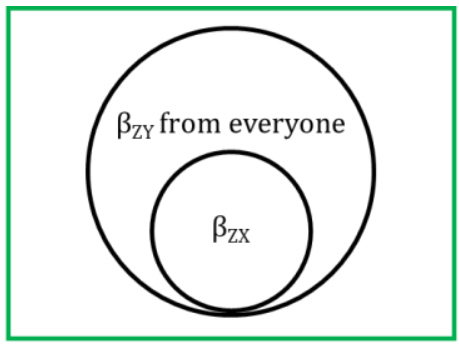

(B) One-sample MR with exposure measured in a random subgroup

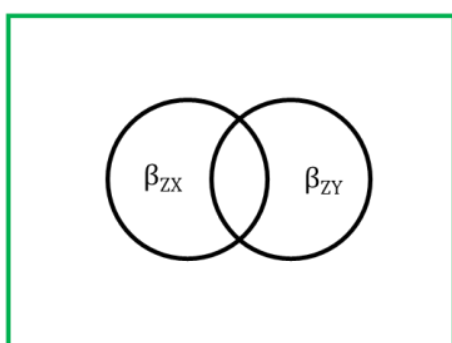

(E) Two-sample MR with overlapping samples

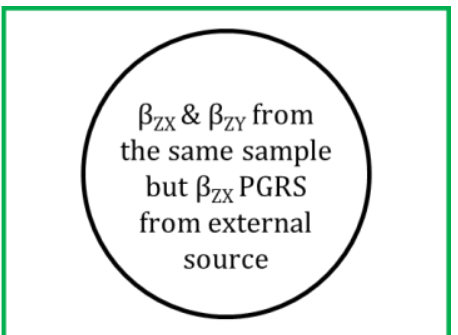

(C) One-sample MR with externally weighted PGRS

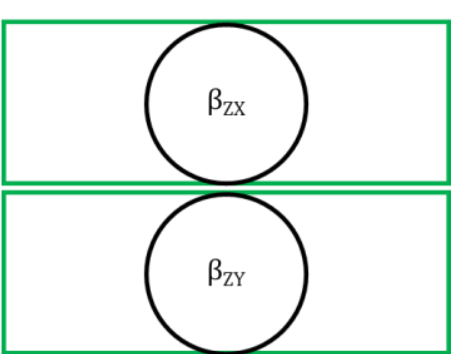

(F) Two-sample MR with different underlying populations
In all examples, the green box represents the same underlying population from which samples are drawn; the black circles represent the samples and the text in these summarises the source of association of genetic instrument with exposure $\left(\beta_{Z X}\right)$ and association of genetic instrument with outcome $\left(\beta_{Z Y}\right)$. In one-sample $M R(A)$ where $\beta_{Z X}$ and $\beta_{Z Y}$ are estimated within the same population, there may be over-fitting of the data because the predicted (by genetic IV) values of $X$ are then used to predict $Y$ in the same sample. In this study type, weak instrument bias will be expected to bias towards the confounded result. In one-sample $M R$, it is not necessary to have exposures measured on all sample participants. For expensive exposures, these could be measured in a subsample (B). The properties and sources of bias will be broadly similar to those in $(A)$, where exposures are measured in all participants, but the likelihood of weak instrument bias may be greater. When $\beta_{Z X}$ is obtained in a one-sample MR study but with external weights (i.e., the

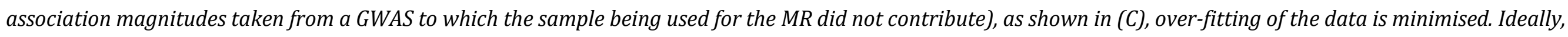

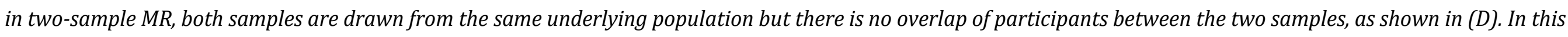

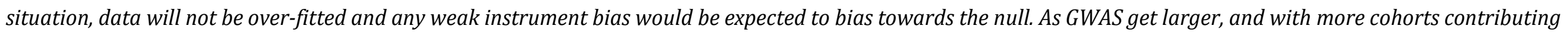

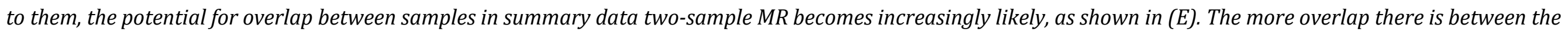

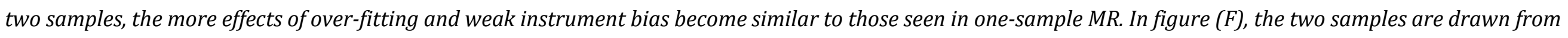

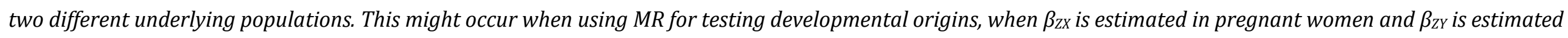

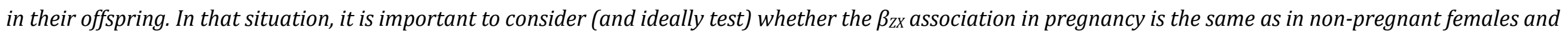

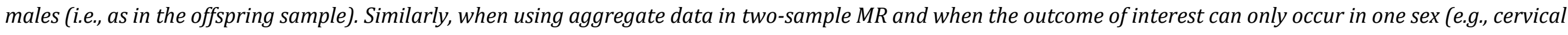

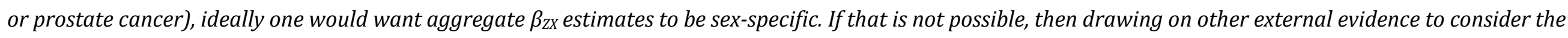
extent to which $\beta_{Z X}$ is likely to be similar in females and males is important. 


\section{Figure 2.7: Two-step Mendelian randomization for exploring mediation}

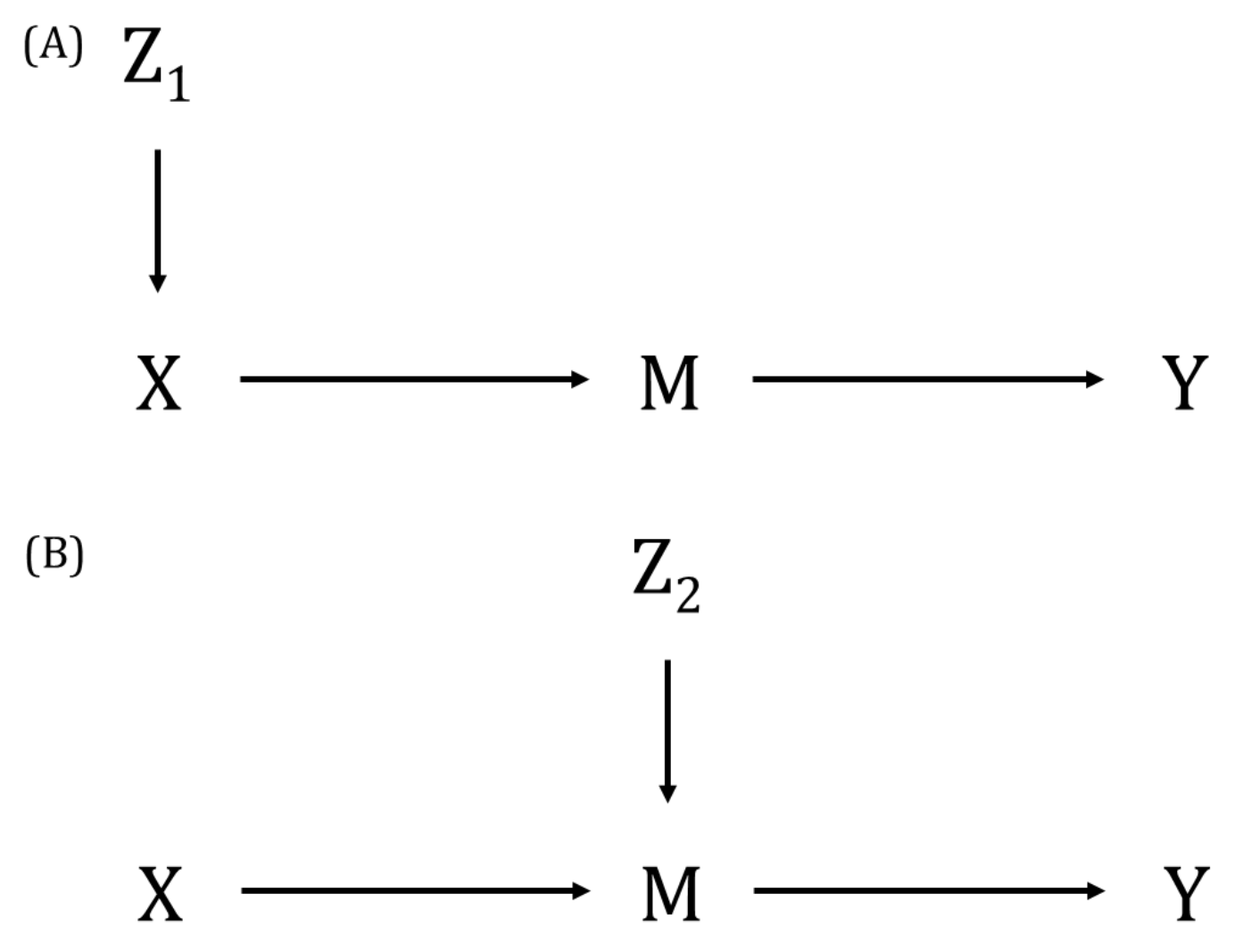

(A) In the first step of two-step $M R$, a genetic variant $\left(Z_{1}\right)$ is used as an instrument for the exposure of interest $(X)$ to estimate the causal impact of the exposure on a hypothesized mediator $(M)$ of the association between the exposure $(X)$ and outcome $(Y)$. (B) In the second step, an independent (of $\left.Z_{1}\right)$ genetic variant ( $Z_{2}$ ) is used as an instrument for the mediator (M) to establish the causal impact of the mediator (M) on the outcome (Y). If there is evidence for a causal effect of X on $M$ and $M$ on $Y$ (as well as X on Y), the estimates from these two steps can be combined to provide evidence for or against the mediating role of a variable on the exposure-outcome effect using e.g., multivariable $M R$ 


\section{Chapter 3: Study designs and terminology related to MR}

\begin{tabular}{|c|c|c|c|}
\hline Term & Brief definition & $\begin{array}{l}\text { Summary of strengths and limitations or other } \\
\text { relevant comments }\end{array}$ & $\begin{array}{l}\text { Useful journal } \\
\text { reference(s) or } \\
\text { references to figures } \\
\text { shown later in the } \\
\text { chapter, if } \\
\text { appropriate }\end{array}$ \\
\hline Candidate gene study & $\begin{array}{l}\text { Studies that assess the association of one or a } \\
\text { small number of genetic variants with a trait. } \\
\text { 'Candidate' genes in such studies are commonly } \\
\text { selected based on hypothesised functional } \\
\text { relevance for the trait being assessed. Candidate } \\
\text { genes might then be used as IVs in } M R \text { studies } \\
\text { testing the effect of that trait on an outcome. }\end{array}$ & $\begin{array}{l}\text { Potential limitations include: } \\
\text { - There is an assumed effect/robust association } \\
\text { with the trait (risk factor of interest in } M R \\
\text { analysis) but this is may not be the case if } \\
\text { replication for the candidate gene has not been } \\
\text { demonstrated in independent studies. } \\
\text { - Single or a few genetic IVs might increase the } \\
\text { likelihood of weak instrument bias. } \\
\text { It may not be feasible to use some IV methods, } \\
\text { such as } M R \text {-Egger and weighted median-based } \\
\text { methods, that provide different means of }\end{array}$ & $(57,58)$ \\
\hline
\end{tabular}




\begin{tabular}{|c|c|c|c|}
\hline & & $\begin{array}{l}\text { exploring instrument validity, with single or } \\
\text { few genetic instruments. } \\
\text { Potential strengths: } \\
\text { - Having knowledge of how genetic IVs function } \\
\text { to influence the risk factor of interest can be } \\
\text { valuable in terms of considering } I V \\
\text { assumptions and the extent to which these are } \\
\text { likely to be violated. }\end{array}$ & \\
\hline $\begin{array}{l}\text { Directed acyclic graph } \\
\text { (DAG) }\end{array}$ & $\begin{array}{l}\text { A DAG is a visual representation of potential } \\
\text { causal relationships between variables. These } \\
\text { relationships are demonstrated by nodes } \\
\text { (representing variables) and arrows (a.k.a. edges } \\
\text { or arches) between variables. The relationship } \\
\text { between two variables in each DAG must be } \\
\text { directed (i.e., there cannot be a bidirectional } \\
\text { relationship). Relationships between all variables } \\
\text { must be acyclic (i.e., a variable cannot have an }\end{array}$ & $\begin{array}{l}\text { DAGs are useful tools for explicitly demonstrating } \\
\text { the underlying assumptions of a proposed } \\
\text { analysis. Arrows are drawn between any two } \\
\text { variables according to the following criteria: } \\
\text { - An arrow from one variable to a second } \\
\text { indicates that you assume that it is plausible } \\
\text { that the first variable causes the second. } \\
\text { - Where there is no arrow between one variable } \\
\text { and a second, this indicates that you assume }\end{array}$ & $\begin{array}{l}\text { (59) } \\
\text { Figure 2.1, Figure 2.3, } \\
\text { Figure 2.4, Figure } \\
\text { 2.5A, Figure 2.7, } \\
\text { Figure } 4.1 \text { and Figure } \\
4.2 \text { are examples of } \\
\text { DAGs }\end{array}$ \\
\hline
\end{tabular}




\begin{tabular}{|c|c|c|c|}
\hline & $\begin{array}{l}\text { impact on itself through any number of other } \\
\text { variables). }\end{array}$ & $\begin{array}{l}\text { that there is no causal relationship between } \\
\text { the first and second variable. } \\
\text { Thus, the three key assumptions of } I V \text { analyses are } \\
\text { illustrated by an arrow from the } I V \text { to exposure; an } \\
\text { absence of an arrow from the } I V \text { to confounders of } \\
\text { exposure and outcome; and an absence of an } \\
\text { arrow from the } I V \text { directly to the outcome. }\end{array}$ & \\
\hline $\begin{array}{l}\text { Gene-Environment }(\mathrm{G} \times \mathrm{E}) \\
\text { interaction study }\end{array}$ & $\begin{array}{l}\text { Studies that assess interaction between (typically) } \\
\text { one genetic variant and a non-genetic factor with } \\
\text { respect to a given outcome. These can be useful in } \\
\text { several MR contexts. For example, some genetic } \\
\text { variants for smoking, alcohol and other risk } \\
\text { factors act on a metabolite or mechanism that is } \\
\text { caused by the risk factor but does not directly } \\
\text { affect levels of the risk factor. In these } \\
\text { circumstances, if the risk factor causes the } \\
\text { outcome of interest, we would only expect the } \\
\text { genetic variant to associate with the outcome in }\end{array}$ & $\begin{array}{l}\text { Sometimes, G×E can be used to investigate } \\
\text { mechanisms. For example, if the genetic variant } \\
\text { blocks the postulated mediating mechanism from } \\
\text { the exposure to the outcome, then the exposure } \\
\text { would not be expected to be associated with the } \\
\text { outcome among carriers of the mediator-blocking } \\
\text { genotype. G×E can be exploited to mitigate bias } \\
\text { due to horizontal pleiotropy in } M R \text {. Adequate } \\
\text { statistical power typically requires very large } \\
\text { samples. Many published studies did not properly } \\
\text { adjust for potential confounders. }\end{array}$ & $(60,61)$ \\
\hline
\end{tabular}




\begin{tabular}{|c|c|c|c|}
\hline & $\begin{array}{l}\text { those who have ever smoked / drunk alcohol or } \\
\text { been exposed to the risk factor. In those who have } \\
\text { never been exposed, we would not expect an } \\
\text { association between the gene and the outcome. } \\
\text { Thus, a G×E, where E is ever versus never } \\
\text { exposure, would provide } M R \text { evidence for a causal } \\
\text { effect. }\end{array}$ & & \\
\hline Genetic colocalization & $\begin{array}{l}\text { The phenomenon whereby genetic factors at a } \\
\text { particular locus are shared between two or more } \\
\text { traits (not to be confused with declaring the exact } \\
\text { causal variant). Tests for genetic colocalization try } \\
\text { to separate between two scenarios: (i) there is a } \\
\text { causal variant for trait A that is distinct from the } \\
\text { causal variant for trait B, whilst being at the same } \\
\text { locus, and (ii) the causal variant for trait A and } \\
\text { trait B are shared. A variety of algorithms exist for } \\
\text { distinguishing between these scenarios, typically }\end{array}$ & $\begin{array}{l}\text { Genetic colocalization of a locus between two traits } \\
\text { is necessary but not sufficient for a causal } \\
\text { relationship, and it can be thought of an } M R \\
\text { analysis performed with a SNP but with an added } \\
\text { sensitivity analysis in which we are trying to rule } \\
\text { out the possibility that there are two distinct } \\
\text { causal variants in the same region. The approach } \\
\text { is regularly used to infer putative causal } \\
\text { relationships between 'omic variables and } \\
\text { complex traits. Often an assumption of these }\end{array}$ & $(62-64)$ \\
\hline
\end{tabular}




\begin{tabular}{|c|c|c|c|}
\hline & $\begin{array}{l}\text { by looking for concordance of effects across all } \\
\text { SNPs at the locus at both traits. }\end{array}$ & $\begin{array}{l}\text { algorithms is that there is only one causal variant } \\
\text { in the region, which may not be appropriate. }\end{array}$ & \\
\hline $\begin{array}{l}\text { Genome-wide association } \\
\text { studies (GWAS) }\end{array}$ & $\begin{array}{l}\text { GWASs are hypothesis-free study designs in which } \\
\text { a panel of (hundreds of thousands or millions) of } \\
\text { genetic variants are each systematically tested for } \\
\text { association with a single trait or disease outcome. } \\
\text { GWASs have the primary objectives of identifying } \\
\text { specific variants that can be used for prediction of } \\
\text { the trait, and for highlighting gene or loci that are } \\
\text { relevant to the aetiology of the trait or disease. } \\
\text { Most genetic effects are small, so GWASs need to } \\
\text { be performed using large biobanks or } \\
\text { collaborations between many studies in which the } \\
\text { GWAS results from all studies are meta-analysed. } \\
\text { Control for confounding due to population } \\
\text { structure, the use of strict significance thresholds } \\
\text { and replication of findings in independent samples } \\
\text { are key features of reliable GWASs. Commonly, }\end{array}$ & $\begin{array}{l}\text { Potential limitations: } \\
\text { - Genome-wide significance is based on a } \\
\text { Bonferroni correction that leads to small } \\
\text { genetic effect estimates being biased upwards } \\
\text { due to winner's curse. The use of these } \\
\text { ('discovery') effect estimates in MR, rather } \\
\text { than those obtained from independent } \\
\text { replication studies can lead to biased effect } \\
\text { estimates. } \\
\text { The function of genetic variants identified from } \\
\text { GWASs (known genome-wide hits) may be } \\
\text { unknown. Particularly for complex traits (such } \\
\text { as BMI), where there is likely to be a chain of } \\
\text { effects or associations from the gene to the } \\
\text { trait, there could be a strong potential for } \\
\text { horizontal pleiotropy. }\end{array}$ & $\begin{array}{l}\text { (65-67) } \\
\text { GWAS catalogue } \\
\text { www.ebi.ac.uk/gwas/ }\end{array}$ \\
\hline
\end{tabular}




\begin{tabular}{|c|c|c|c|}
\hline & $\begin{array}{l}\text { GWAS results are visualised using a Manhattan } \\
\text { plot, which shows the } \log _{10}(\mathrm{p} \text {-value) of each } S N P \\
\text { by the location of that } S N P \text { in the genome by } \\
\text { chromosome. All variants that associate with the } \\
\text { trait at genome-wide significance are then } \\
\text { commonly used as genetic instruments in } M R \\
\text { studies. }\end{array}$ & $\begin{array}{l}\text { With sample sizes growing ever larger, the risk } \\
\text { of subtle population stratification or dynastic } \\
\text { effects leading to false positive or biased GWAS } \\
\text { findings is growing. } \\
\text { Potential strengths when used to identify genetic } \\
\text { IVs: } \\
\text { - Most GWAS will highlight genetic variants that } \\
\text { replicate in (large) independent studies. } \\
\text { Where several variants are identified as } \\
\text { potential instruments for a trait, several } \\
\text { statistical methods each with differing } \\
\text { assumptions can be used and triangulation of } \\
\text { results across them. }\end{array}$ & \\
\hline Genome-wide significance & $\begin{array}{l}\text { Genome-wide significance is widely defined as } \\
\text { having a statistical association in which the p- } \\
\text { value } \leq 5 \times 10^{-8} \text { in a GWAS. }\end{array}$ & $\begin{array}{l}\text { As with all p-value thresholds for 'statistical } \\
\text { significance', the value is arbitrary. The threshold } \\
\text { of } \leq 5 \times 10^{-8} \text { was a Bonferroni correction of the } \\
\text { commonly used } p \leq 0.05 \text {, based on the estimated } \\
\text { number of independent tests in the GWAS if all }\end{array}$ & $(68,69)$ \\
\hline
\end{tabular}




\begin{tabular}{|c|c|c|c|}
\hline & & $\begin{array}{l}\text { common SNPs in the first version of HapMap were } \\
\text { tested with direct genotyping or imputation (i.e., } \\
0.05 / 10^{6} \text { ). More stringent thresholds should be } \\
\text { used if the study also included rare variants. The } \\
\text { major feature of a reliable genetic association; } \\
\text { however, is replication in an independent sample. }\end{array}$ & \\
\hline $\begin{array}{l}\text { Imputation of genetic } \\
\text { variants in GWAS }\end{array}$ & $\begin{array}{l}\text { Genotyping assays are a cost-effective way of } \\
\text { recording genotypes on hundreds of thousands of } \\
\text { positions across the genome and across many } \\
\text { individuals. However, there are in excess of } 10 \\
\text { million common genetic variants in human } \\
\text { populations and drastically more rare variants. } \\
\text { This can be treated as a missing data problem, } \\
\text { where there are a few hundred thousand known } \\
\text { variables and many million unknown variables in } \\
\text { a dataset. Genetic imputation makes probabilistic } \\
\text { inference of the unknown variables by matching }\end{array}$ & $\begin{array}{l}\text { Jointly analysing GWAS results from multiple } \\
\text { cohorts is key to improving sample sizes to the } \\
\text { point that small effects can be detected at } \\
\text { stringent genome-wide significance levels. } \\
\text { However, different cohorts often use different } \\
\text { genotyping platforms, which means that } \\
\text { combining the data in totality is not possible. } \\
\text { Genetic imputation has been crucial for enabling } \\
\text { very large GWAS sample sizes because if each } \\
\text { cohort imputes to the same reference panel then } \\
\text { they then have a set of common variables across } \\
\text { the genome. Genetic imputation is now very }\end{array}$ & (70) \\
\hline
\end{tabular}




\begin{tabular}{|c|c|c|c|}
\hline & $\begin{array}{l}\text { haplotypes within the sample with haplotypes } \\
\text { from a sequenced reference dataset. }\end{array}$ & $\begin{array}{l}\text { effective at inferring common variants, but rare } \\
\text { variants tend to how low imputation accuracy. }\end{array}$ & \\
\hline Replication & $\begin{array}{l}\text { Refers to demonstrating consistency of results } \\
\text { between independent studies. It is one method for } \\
\text { guarding against the promotion of 'false' results. } \\
\text { In relation to MR, genetic variants that are used as } \\
\text { IVs should be shown to have consistent results } \\
\text { across two (or ideally more) independent studies. }\end{array}$ & $\begin{array}{l}\text { Replication has commonly been defined as } \\
\text { associations across studies being 'statistically } \\
\text { significant'. This assumes similar statistical power } \\
\text { across studies and showing consistency of } \\
\text { direction and magnitude of association might also } \\
\text { be valuable. }\end{array}$ & (71) \\
\hline Triangulation & $\begin{array}{l}\text { Triangulation, in epidemiology, refers to } \\
\text { integrating and comparing results from several } \\
\text { studies (or several different methods applied to } \\
\text { the same study data) that use different } \\
\text { approaches to test causal effects, where each } \\
\text { approach has different (and unrelated) key } \\
\text { sources of bias. Ideally with the different key } \\
\text { sources of bias in different studies resulting in } \\
\text { bias in different directions. }\end{array}$ & $\begin{array}{l}\text { If results from } M R \text { 'triangulate' with those from } \\
\text { other approaches (with different key sources of } \\
\text { bias), this increases confidence that those similar } \\
\text { results are the correct causal effect. The use of } \\
\text { different } M R \text { methods (with different assumptions } \\
\text { and key sources of biases) can also be valuable to } \\
\text { increase confidence in } M R \text { results, where } \\
\text { consistent results across methods are observed. }\end{array}$ & $(72)$ \\
\hline
\end{tabular}


Chapter 4: Terms commonly used when describing sources of bias or limitations in Mendelian randomization and specific situations where Mendelian randomization may have additional limitations

\begin{tabular}{|c|c|c|c|}
\hline Term & Brief definition & $\begin{array}{l}\text { Comments on relevance to MR / how these might } \\
\text { be explored }\end{array}$ & $\begin{array}{l}\text { Useful journal } \\
\text { reference(s) or } \\
\text { references to } \\
\text { figures shown } \\
\text { later in the } \\
\text { chapter, if } \\
\text { appropriate }\end{array}$ \\
\hline Assortative mating & $\begin{array}{l}\text { Occurs when people choose their partners based on } \\
\text { particular characteristics, such as height, intelligence, } \\
\text { rather than at random. Single-trait assortative mating } \\
\text { is characterised by assortment on a single trait (e.g., } \\
\text { taller women tend to partner with taller men; mid- } \\
\text { height men tend to mate with shorter women). Cross- } \\
\text { trait assortative mating occurs when, for example, } \\
\text { men with high values of one trait tend to partner with } \\
\text { women with either higher or lower values of another }\end{array}$ & $\begin{array}{l}\text { Cross-trait assortment on the exposure and outcome } \\
\text { leads to a spurious genetic correlation between } \\
\text { parents, which renders the exposure and outcome } \\
\text { phenotypes genetically correlated in the offspring. In } \\
\text { some cases, single-trait assortative mating can lead to } \\
\text { the same phenomenon. Such spurious genetic } \\
\text { correlation can lead to bias in } M R \text {. If available parent's } \\
\text { genetic data can be used to detect, and adjusted for, } \\
\text { any bias from assortative mating. }\end{array}$ & $(26,73)$ \\
\hline
\end{tabular}




\begin{tabular}{|c|c|c|c|}
\hline & $\begin{array}{l}\text { trait (e.g., more educated men tend to partner with } \\
\text { taller women). }\end{array}$ & & \\
\hline Canalization & $\begin{array}{l}\text { The process by which potentially disruptive influences } \\
\text { on normal development from genetic (and } \\
\text { environmental) exposures are damped or buffered by } \\
\text { compensatory developmental processes. This results } \\
\text { from animals (including humans) being relatively } \\
\text { 'plastic' during development periods. For example, } \\
\text { hypothetically fetuses with genetic variants that result } \\
\text { in on average higher glucose levels might develop } \\
\text { other compensatory systems in such a way that higher } \\
\text { glucose levels do not adversely affect them. }\end{array}$ & $\begin{array}{l}\text { It is not directly possible to determine. If canalization } \\
\text { has occurred, then genetic IVs may still relate to the } \\
\text { risk factor by the same magnitude (as in the absence of } \\
\text { any canalization) but the effect on a potential outcome } \\
\text { of that risk factor could be dampened. Biological } \\
\text { evidence for canalization having a marked impact on } \\
\text { genetic associations is lacking. This will not impact } M R \\
\text { results when assessing intrauterine effects (i.e., via } \\
\text { maternal genetic IVs for maternal pregnancy risk } \\
\text { factors) on offspring outcomes, as the mother's } \\
\text { genotype will not have been influenced by canalization } \\
\text { in the offspring (though this has additional potential } \\
\text { problems - see } M R \text { for testing developmental origins } \\
\text { below). }\end{array}$ & $(1,30)$ \\
\hline Collider & $\begin{array}{l}\text { In an epidemiological setting, a collider is a variable } \\
\text { that is caused by both the exposure and the outcome }\end{array}$ & $\begin{array}{l}\text { Adjusting for a collider in any epidemiological setting } \\
\text { can induce an association between the exposure and }\end{array}$ & $\begin{array}{l}(59) \\
\text { Figure } 4.1\end{array}$ \\
\hline
\end{tabular}




\begin{tabular}{|c|c|c|c|}
\hline & $\begin{array}{l}\text { of interest. The term 'collider' refers to the fact that, in } \\
\text { a } D A G \text {, arrow heads showing directional associations } \\
\text { from the two exposure and outcome variables collide } \\
\text { into a third variable (the collider). }\end{array}$ & $\begin{array}{l}\text { outcome (see collider bias). In an MR context, collider } \\
\text { bias can be induced if adjusting for a collider (e.g., the } \\
\text { exposure would be a collider of the genetic instrument } \\
\text { and confounding factors). }\end{array}$ & \\
\hline Collider bias & $\begin{array}{l}\text { Collider bias occurs when a model is adjusted for a } \\
\text { collider or the descendant of a collider. This can occur } \\
\text { when there is selection bias (e.g., because of a very low } \\
\text { response into the study, loss to follow-up or missing } \\
\text { data). It can also occur when analyses are restricted to } \\
\text { subgroups of a population, such as the Nurse's or } \\
\text { Physician's Health studies, other occupational based } \\
\text { cohorts, or when studying people with a specific } \\
\text { disease (e.g., when looking at the effect of a risk factor } \\
\text { or treatment on prognosis/disease progression). The } \\
\text { resulting bias in the exposure-outcome causal effect } \\
\text { estimate can be in either direction, can mask an effect } \\
\text { so that it falsely appears null, or can induce an effect } \\
\text { when none exists. }\end{array}$ & $\begin{array}{l}\text { In } M R \text { for testing developmental origins/intrauterine } \\
\text { effects, adjustment for potential violation of } I V \\
\text { assumptions via fetal genetic variants by adjusting for } \\
\text { the fetal genetic variants can generate a spurious } \\
\text { association between mother's and father's genetic } \\
\text { variants (because maternal and paternal genetic } \\
\text { variants collide on fetal/offspring genetic variants). If } \\
\text { it is not possible to adjust for paternal genetic variants } \\
\text { (this is often the case) and the paternal phenotype } \\
\text { affects the offspring outcome, then the MR result is } \\
\text { likely to be biased. New methods for separating } \\
\text { maternal and fetal genetic effects and availability of } \\
\text { genetic data on trios can be used to mitigate this. MR in } \\
\text { people with diseases to explore its progression or }\end{array}$ & $\begin{array}{l}(26,27,59,74,75) \\
\text { Figure } 4.1\end{array}$ \\
\hline
\end{tabular}




\begin{tabular}{|c|c|c|c|c|}
\hline & & & $\begin{array}{l}\text { results to treatments may be affected by collider bias. } \\
\text { For example, if a hypothesised risk factor and disease } \\
\text { progression both influence being diagnosed or } \\
\text { selected into the study, they are colliding on study } \\
\text { selection and this will generate a spurious association } \\
\text { between them. The extent to which this has a major } \\
\text { effect in different studies is a subject of active } \\
\text { research. In two-sample MR, where summary data have } \\
\text { been adjusted (e.g., the GWAS of waist-hip ratio } \\
\text { adjusted for BMI) the use of these adjusted data can } \\
\text { introduce collider bias. }\end{array}$ & \\
\hline Confounding & & $\begin{array}{l}\text { aditional definition of a confounder is that: } \\
\text { It is associated with the exposure } \\
\text { It is associated with the outcome conditional } \\
\text { upon the exposure } \\
\text { It is not on the causal pathway between the } \\
\text { exposure and outcome. }\end{array}$ & $\begin{array}{l}\text { Associations of genetic variants with outcomes are } \\
\text { generally less prone than associations of non-genetic } \\
\text { characteristics to confounding by many socio- } \\
\text { demographic, lifestyle and clinical characteristics from } \\
\text { across the lifecourse. The 'independence' IV } \\
\text { assumption states that IVs are not associated with } \\
\text { confounders of the risk factor-outcome association. In }\end{array}$ & $(26,76)$ \\
\hline
\end{tabular}




\begin{tabular}{|c|c|c|c|}
\hline & $\begin{array}{l}\text { However, because this set of rules does not generalize } \\
\text { to complex modelling structures, the modern } \\
\text { interpretation uses Pearl's directional-separation } \\
\text { rules. In this context, the modern definition of } \\
\text { confounding is the existence of an open "backdoor } \\
\text { pathway" between the exposure and outcome - where } \\
\text { one or more characteristics influence the risk factor } \\
\text { and outcome of interest and generate a spurious } \\
\text { (confounded) association between risk factor and } \\
\text { outcome. Confounding can generate a positive or } \\
\text { negative association when there is no causal effect of } \\
\text { risk factor on outcome and can exaggerate or } \\
\text { attenuate a true causal effect. }\end{array}$ & $\begin{array}{l}M R \text { studies, demonstrating that genetic IVs are not } \\
\text { related to observed risk factor-outcome confounders } \\
\text { is important (though we cannot show they are not } \\
\text { related to unobserved confounders). In two-sample MR } \\
\text { with summary (aggregate) data, it may not be possible } \\
\text { to explore associations with observed risk factor- } \\
\text { outcome confounders in the outcome sample (sample } \\
\text { 2). However, summary-level data from GWAS for any } \\
\text { known or hypothesised confounders may be available } \\
\text { and if so these should be used to explore whether } \\
\text { there are associations with the risk factor-outcome } \\
\text { confounders. }\end{array}$ & \\
\hline Dynastic effects & $\begin{array}{l}\text { Dynastic effects are the potential for } M R \text { causal } \\
\text { estimates to be confounded by characteristics that are } \\
\text { transmitted across generations. For example, an } M R \\
\text { study of the effect of height on coronary heart disease } \\
\text { might be biased by a dynastic effect through a }\end{array}$ & $\begin{array}{l}\text { It is difficult to detect the magnitude of any bias } \\
\text { resulting from this. It is less likely to occur in } M R \\
\text { studies of 'own' risk factors (as opposed to } \\
\text { intrauterine exposures from maternal pregnancy risk } \\
\text { factors), that are not 'visible' and, hence, not likely }\end{array}$ & $(26,77)$ \\
\hline
\end{tabular}




\begin{tabular}{|c|c|c|c|}
\hline & $\begin{array}{l}\text { confounding path linking genetic instruments for } \\
\text { height to coronary heart disease via the correlation } \\
\text { between own and mother's height genes and the } \\
\text { possibility that maternal height influences fetal growth } \\
\text { and development in utero, which influences future } \\
\text { offspring (own) heart disease. }\end{array}$ & $\begin{array}{l}\text { copied from parents by offspring. Triangulation of } M R \\
\text { findings with those from other methods that have } \\
\text { different and unrelated potential causes of bias can } \\
\text { help improve confidence about whether } M R \text { results are } \\
\text { markedly biased by these effects. }\end{array}$ & \\
\hline $\begin{array}{l}\text { (no) Effect } \\
\text { modification } \\
\text { assumption) } \\
\text { (Additional IV } \\
\text { assumption) }\end{array}$ & $\begin{array}{l}\text { This is one of a set of additional (to the core) } I V \\
\text { assumptions that are required for a well-defined } \\
\text { causal parameter. }\end{array}$ & $\begin{array}{l}\text { If the genetic IV does not modify the effect of the } \\
\text { exposure on the outcome within levels of the exposure } \\
\text { and for all levels of the exposure, then this assumption } \\
\text { holds and } I V \text { estimate is consistent for the ACE even if } \\
\text { the effect of the exposure on the outcome is } \\
\text { heterogeneous (see Homogeneity assumption). As } \\
\text { noted in Chapter } 3 \text {, when there is biological } \\
\text { understanding, a Gene-Environment (G×E) interaction } \\
\text { study can provide evidence of causality. In more } \\
\text { general, } M R \text { studies biological evidence may provide } \\
\text { evidence against effect modification being plausible. }\end{array}$ & $\begin{array}{l}(50-52) \\
\text { See Instrumental } \\
\text { variable (IV) } \\
\text { above. }\end{array}$ \\
\hline
\end{tabular}




\begin{tabular}{|c|c|c|}
\hline & 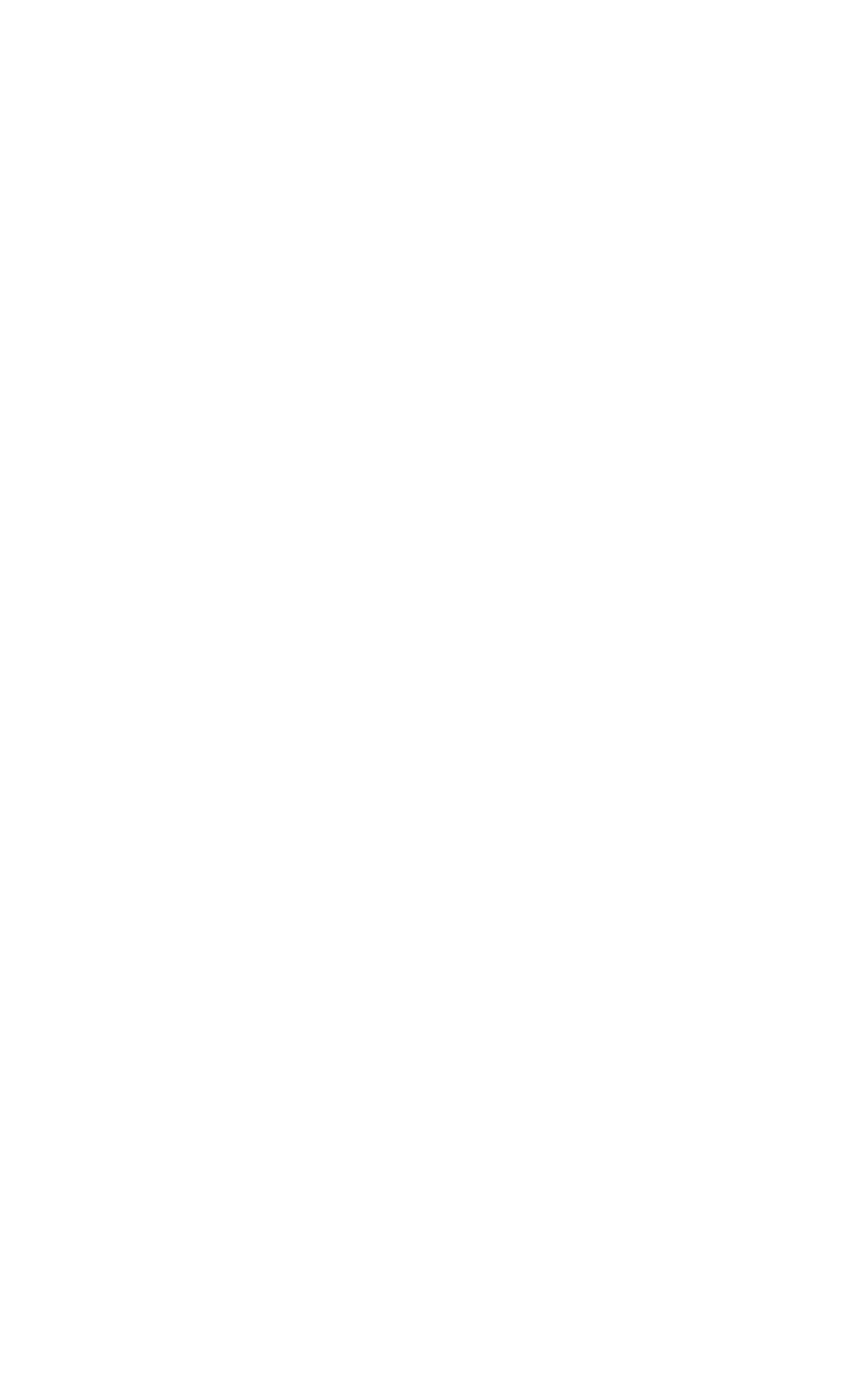 & $\begin{array}{l}\text { Monotonicity (a weaker assumption) might be used } \\
\text { but for some } M R \text { causal estimates. It is difficult in } \\
\text { practice to know how important violation of these } \\
\text { additional IV assumptions are in } M R \text { studies. Large } \\
\text { GWAS collaborations increasingly combine results } \\
\text { from many studies (though mostly from European } \\
\text { original populations) and show consistency of } \\
\text { association across these studies for variants defined as } \\
\text { being associated with the exposure at genome-wide } \\
\text { significance (variants used in most MR studies), } \\
\text { suggesting homogeneity may exist for several } M R \\
\text { studies in European populations. Non-parametric } \\
\text { methods that provide bounds of causal effect estimates } \\
\text { requiring only the core } I V \text { assumptions may be } \\
\text { applicable for some } M R \text { studies Triangulation of } \\
\text { results with other (non-MR) methods is likely to } \\
\text { improve causal inference from } M R \text { studies. }\end{array}$ \\
\hline
\end{tabular}




\begin{tabular}{|c|c|c|c|}
\hline $\begin{array}{l}\text { Exclusion restriction } \\
\text { (IV3 core assumption) }\end{array}$ & $\begin{array}{l}\text { Known as the third } I V \text { assumption, this states that the } \\
I V \text { is not related to the outcome other than via the risk } \\
\text { factor of interest. }\end{array}$ & $\begin{array}{l}\text { In general, } M R \text { this may be violated by horizontal } \\
\text { pleiotropy. In } M R \text { exploring effects of maternal (or } \\
\text { paternal) exposure on offspring, this may be violated } \\
\text { by fetal (offspring genotype) (see also MR for testing } \\
\text { developmental origins). }\end{array}$ & $\begin{array}{l}(26,29,30,78) \\
\text { See Instrumental } \\
\text { variable (IV) } \\
\text { above. }\end{array}$ \\
\hline $\begin{array}{l}\text { Harmonization failure } \\
\text { (in two-sample MR) }\end{array}$ & $\begin{array}{l}\text { When one or more genetic IVs have different effect } \\
\text { allele between exposure and outcome datasets of } \\
\text { summary association results. This is of greater } \\
\text { concern for palindromic variants with high minor } \\
\text { allele frequency, especially when strand issues are a } \\
\text { possibility (Figure 1.1). }\end{array}$ & $\begin{array}{l}\text { To overcome errors due to harmonization, it is advised } \\
\text { to harmonize using automated scripts that have been } \\
\text { thoroughly tested (for example, those used in } M R \text { - } \\
\text { Base) and check the correlation between effect allele } \\
\text { frequencies before and after harmonizing. It is also } \\
\text { useful to provide pre- and post-harmonization } \\
\text { datasets to allow assessment of the quality of the } \\
\text { harmonization and perform sensitivity analysis to } \\
\text { evaluate the influence of variants difficult to } \\
\text { harmonize (e.g., palindromic variants with high minor } \\
\text { allele frequency). }\end{array}$ & $(16,17,39)$ \\
\hline
\end{tabular}




\begin{tabular}{|c|c|c|c|}
\hline $\begin{array}{l}\text { Homogeneity } \\
\text { Assumption }\end{array}$ & $\begin{array}{l}\text { This is one of a set of additional (to the core) } I V \\
\text { assumptions that are required for a well-defined } \\
\text { causal parameter. }\end{array}$ & $\begin{array}{l}\text { The assumption is that either: } \\
\text { - the association between the genetic } I V \text { and the } \\
\text { exposure is homogeneous (i.e., is the same for } \\
\text { everyone in the population) or } \\
\text { the effect of the exposure on the outcome is } \\
\text { homogeneous. } \\
\text { If this assumption holds then the IV estimate is } \\
\text { consistent with the average causal effect (ACE) for the } \\
\text { population to which inference is being made. } \\
\text { Increasing biological knowledge of genetic variant } \\
\text { functionality may provide evidence for some genetic } \\
\text { instruments fulfilling this assumption. 'Weaker' } \\
\text { assumptions (no effect modification and monotonicity) } \\
\text { can alternatively be evoked. It is difficult in practice to } \\
\text { know how important violation of these additional } I V \\
\text { assumptions are in } M R \text { studies. Large } G W A S \\
\text { mallaborations increasingly combine results from } \\
\text { many studies (though mostly from European original }\end{array}$ & $\begin{array}{l}(50-52) \\
\text { See Instrumental } \\
\text { variable (IV) } \\
\text { above. }\end{array}$ \\
\hline
\end{tabular}




\begin{tabular}{|c|c|c|c|}
\hline & & $\begin{array}{l}\text { populations) and show consistency of association } \\
\text { across these studies for variants defined as associated } \\
\text { with the exposure at genome-wide significance } \\
\text { (variants used in most } M R \text { studies), suggesting } \\
\text { homogeneity may exist for several } M R \text { studies in } \\
\text { European populations. Non-parametric methods that } \\
\text { provide bounds of causal effect estimates requiring } \\
\text { only the core } I V \text { assumptions may be applicable for } \\
\text { some } M R \text { studies. Triangulation of results with other } \\
\text { (non- } M R \text { ) methods is likely to improve causal } \\
\text { inference from } M R \text { studies. }\end{array}$ & \\
\hline $\begin{array}{l}\text { Horizontal Pleiotropy } \\
\text { (a key way in which } \\
\text { MR may violate the } \\
\text { exclusion restriction } \\
\text { assumption) }\end{array}$ & $\begin{array}{l}\text { Also known as "genuine" or "true" pleiotropy. This is } \\
\text { when a genetic variant affects other traits which } \\
\text { influence the outcome independently of the } \\
\text { hypothesised exposure. }\end{array}$ & $\begin{array}{l}\text { This can result in biased } M R \text { estimates because of } \\
\text { violation of the exclusion restriction assumption. For } \\
\text { example, if some or all of the genetic IVs that robustly } \\
\text { associate with the risk factor of interest also, } \\
\text { independently of the association with the risk factor, } \\
\text { associate with other risk factors for the outcome, then } \\
\text { the } M R \text { estimate will be the combined effect of all of }\end{array}$ & $\begin{array}{l}(32,45) \\
\text { Figure 2.4, Figure } \\
4.2\end{array}$ \\
\hline
\end{tabular}




\begin{tabular}{|c|c|c|c|}
\hline & & $\begin{array}{l}\text { these (independent) risk factors - not the effect of the } \\
\text { risk factor of interest alone. Methods such as } M R \text { - } \\
\text { Egger, weighted median- and mode-based MR methods } \\
\text { have been developed to explore and account for the } \\
\text { impact of horizontal pleiotropy in } M R \text { studies (see } \\
\text { Chapter 4). This can also be informative about the } \\
\text { trait's aetiology (see } M R \text {-TRYX). }\end{array}$ & \\
\hline $\begin{array}{l}\text { Independence (IV2 } \\
\text { assumption) }\end{array}$ & $\begin{array}{l}\text { Known as the second } I V \text { assumption (and sometimes } \\
\text { also referred to as the "exchangeability" assumption) } \\
\text { this states that } I V \text { s are not associated with } \\
\text { confounders of the risk factor-outcome association }\end{array}$ & $\begin{array}{l}\text { As genetic variants are determined at conception it is } \\
\text { not possible for them to be affected by confounders of } \\
\text { risk factor-outcome associations, but they could } \\
\text { influence these confounders. If they do and these } \\
\text { confounders are not measured / not controlled for in } \\
\text { the } M R \text { analysis then a path from the genetic IV via } \\
\text { these confounders could bias the causal effect } \\
\text { estimate. As noted above under confounding in both } \\
\text { one-sample and two-sample MR, associations of the } \\
\text { genetic } I V \text { with potential confounders should be }\end{array}$ & $(52,76)$ \\
\hline
\end{tabular}




\begin{tabular}{|c|c|c|c|}
\hline & & $\begin{array}{l}\text { undertaken and methods such as multivariable } M R \\
\text { used to control for these where possible. }\end{array}$ & \\
\hline $\begin{array}{l}\text { InSIDE assumption (in } \\
\text { Two-sample MR using } \\
\text { aggregate data) }\end{array}$ & $\begin{array}{l}\text { The Instrument Strength Independent of Direct Effect } \\
\text { (InSIDE) assumption a further assumption for } M R \text { - } \\
\text { Egger and related } M R \text { methods (additional to core and } \\
\text { additional } I V \text { assumptions outlined in Chapter 2). }\end{array}$ & $\begin{array}{l}\text { The assumption states that the association between } \\
\text { the genetic instrument and exposure is not correlated } \\
\text { with path from the genetic instrument to the outcome } \\
\text { that is independent of the exposure of interest. If } \\
\text { unbalanced pleiotropy is present and the InSIDE } \\
\text { assumption is violated, then this is likely to result in a } \\
\text { biased MR-Egger effect. Violation of the InSIDE } \\
\text { assumption can occur if several genetic variants } \\
\text { influence the outcome via the same pleiotropic path or } \\
\text { if several variants are related to the same risk factor- } \\
\text { outcome (unmeasured) confounder(s), as then the } \\
\text { genetic instrument-exposure association is in part via } \\
\text { that (those) confounders and it is also related to the } \\
\text { outcome via the same confounder(s). }\end{array}$ & $(15,79)$ \\
\hline
\end{tabular}




\begin{tabular}{|c|c|c|c|}
\hline $\begin{array}{l}\text { Monotonicity (IV4 } \\
\text { assumption) }\end{array}$ & $\begin{array}{l}\text { This is one of a set of additional (to the core) } I V \\
\text { assumptions that are required for a well-defined } \\
\text { causal parameter. }\end{array}$ & $\begin{array}{l}\text { Two types of monotonicity may be inferred to make } \\
\text { causal inference in } I V \text { (including } M R \text { studies) } \\
\text { - Deterministic monotonicity: often referred to } \\
\text { simply as "monotonicity", which assumes a } \\
\text { monotonic relationship between the } I V \text { and } \\
\text { exposure. In other words, a genetic } I V \text { could not } \\
\text { increase the exposure in some people and } \\
\text { decrease it in others. If this monotonicity holds, } \\
\text { then the } I V \text { estimate is consistent with the ACE } \\
\text { among compliers, where compliers are the } \\
\text { subgroup of the sample affected by the genetic } I V \text {. } \\
\text { Defining who this subgroup might be is unclear. } \\
\text { Stochastic monotonicity: this is a relaxation of } \\
\text { deterministic monotonicity, because this only } \\
\text { requires that a monotonic increasing association } \\
\text { between the } I V \text { and the exposure exists } \\
\text { conditionally on a set of covariates (which may or } \\
\text { may not be measured). If this holds, then the } I V\end{array}$ & $\begin{array}{l}(50-52) \\
\text { See Instrumental } \\
\text { variable (IV) } \\
\text { above. }\end{array}$ \\
\hline
\end{tabular}




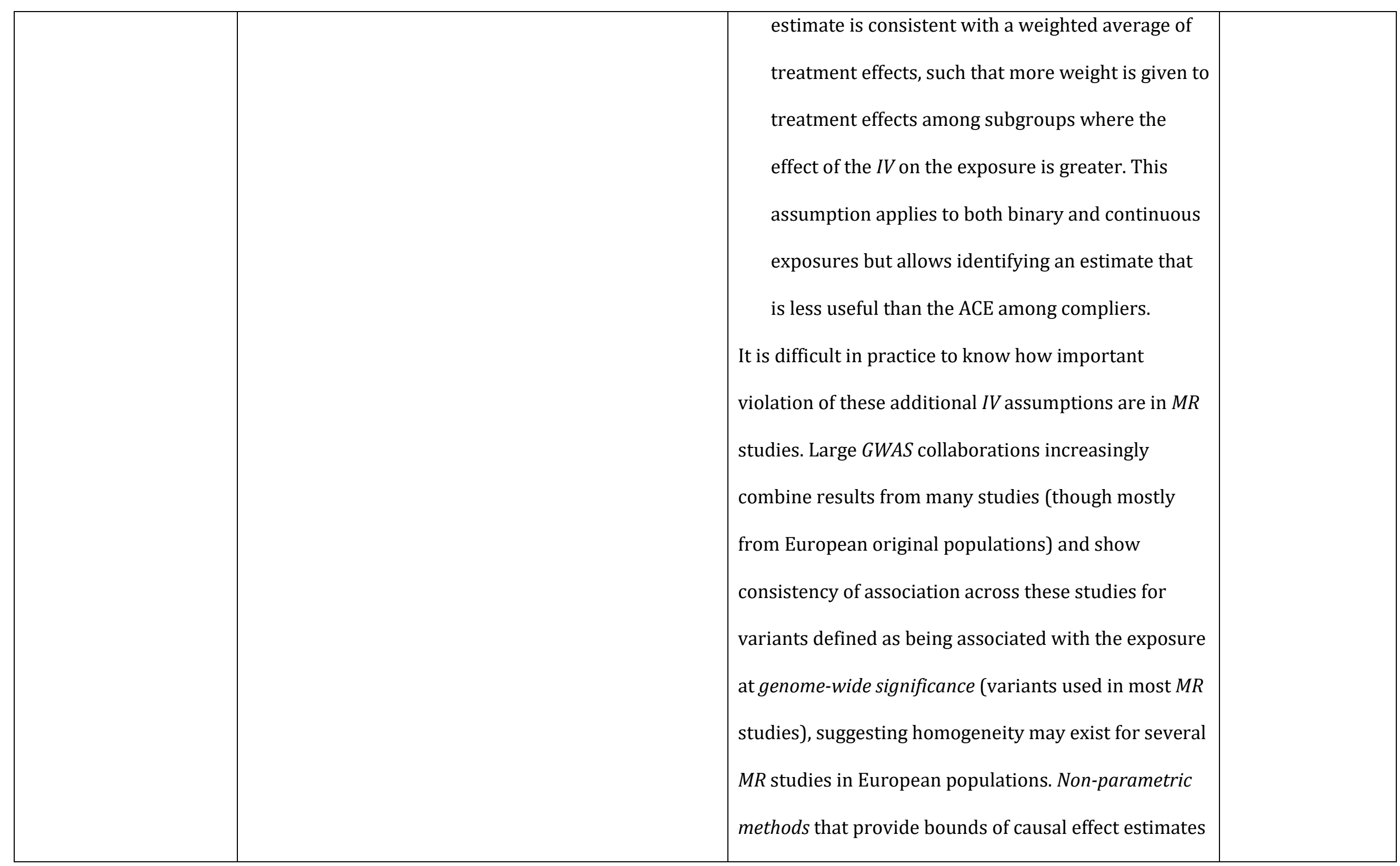




\begin{tabular}{|c|c|c|c|}
\hline & & $\begin{array}{l}\text { requiring only the core } I V \text { assumptions may be } \\
\text { applicable for some } M R \text { studies. Triangulation of } \\
\text { results with other (non- } M R \text { ) methods is likely to } \\
\text { improve causal inference from } M R \text { studies. }\end{array}$ & \\
\hline $\begin{array}{l}\text { MR for testing critical } \\
\text { or sensitive periods }\end{array}$ & $\begin{array}{l}\text { As genetic variants are fixed at conception, in general, } \\
\text { they instrument a life-course predisposition to a } \\
\text { particular risk factor. This makes } M R \text { less prone to } \\
\text { regression dilution bias, but such genetic variants might } \\
\text { be unsuited to testing the effects of risk factors that } \\
\text { are believed to act during critical (a time period in } \\
\text { which the risk factor is hypothesised to solely have its } \\
\text { effect) or sensitive (a period during which the risk } \\
\text { factor is hypothesised to have the greatest effect) } \\
\text { periods. }\end{array}$ & $\begin{array}{l}\text { If the research question is about determining an effect } \\
\text { in a critical or sensitive period (i.e., showing an } \\
\text { exposure only affects an outcome when it occurs } \\
\text { during a specific age range and not at other life times } \\
\text { or has a stronger effect when it occurs during a } \\
\text { specific time of life), MR may not be a useful method as } \\
\text { the result it will provide is the mean effect of the } \\
\text { exposure across all/most of the life course. As GWASs } \\
\text { of trajectories (e.g., change in weight or height across } \\
\text { infancy childhood and into early adulthood) are } \\
\text { undertaken, they may provide genetic } I V \text { s that could } \\
\text { be used in } M R \text { to compare change in an exposure } \\
\text { between two ages with change in the same exposure } \\
\text { between two later ages and compare these to see if }\end{array}$ & $(26,72)$ \\
\hline
\end{tabular}




\begin{tabular}{|c|c|c|c|}
\hline & & $\begin{array}{l}\text { there are differences in the effect at different ages. } \\
\text { This is likely to need very large sample sizes. }\end{array}$ & \\
\hline $\begin{array}{l}\text { MR for testing } \\
\text { developmental origins }\end{array}$ & $\begin{array}{l}\text { The Developmental Origins of Health and Disease } \\
\text { (DOHaD) hypothesis suggests that risk factors during } \\
\text { intrauterine or early infancy development periods } \\
\text { have a causal effect on future offspring health. MR has } \\
\text { been used to test intrauterine effects by using genetic } \\
\text { instruments for maternal risk factors during } \\
\text { pregnancy and exploring their effects on offspring } \\
\text { outcomes. } \\
\text { Note: DOHaD does not necessarily assume a critical or } \\
\text { sensitive periods but rather that exposures in utero are } \\
\text { hypothesised to have a lasting effect. Some DOHaD } \\
\text { hypotheses do propose that an exposure only has an } \\
\text { effect during the intrauterine period (or that any } \\
\text { exposures has a stronger effect then); for those the } \\
\text { considerations for } M R \text { for testing critical or sensitive } \\
\text { periods apply. }\end{array}$ & $\begin{array}{l}\text { As genetic variants are usually identified from GWAS of } \\
\text { men and (non-pregnant) women, it is assumed that } \\
\text { these relate to the risk factor in women during } \\
\text { pregnancy in the same way as they do in the GWAS } \\
\text { populations. This should be explored where possible. } \\
\text { Offspring genetic variants are a potential source of } \\
\text { violation of the exclusion restriction but adjustment for } \\
\text { offspring genotype can introduce a spurious } \\
\text { association between maternal and paternal genotype } \\
\text { (i.e., collider bias). If there is no information on } \\
\text { paternal genotype (so it cannot be adjusted for), this } \\
\text { can bias the causal effect of maternal pregnancy risk } \\
\text { factor on offspring outcome. Adjustment for offspring } \\
\text { and paternal genotype (where available), non- } \\
\text { transmitted allele analyses, structural-equation }\end{array}$ & $(26,27)$ \\
\hline
\end{tabular}




\begin{tabular}{|c|c|c|c|}
\hline & & $\begin{array}{l}\text { modelling approaches and simulation studies can help } \\
\text { explore the extent of bias via offspring genotype. }\end{array}$ & \\
\hline Non-linear effects & $\begin{array}{l}\text { Most } M R \text { studies assume a linear (dose-response) } \\
\text { effect of the risk factor on outcome. Methods for } \\
\text { exploring non-linear effects in one-sample and two- } \\
\text { sample } M R \text { have been developed but require very large } \\
\text { numbers to be adequately powered. }\end{array}$ & $\begin{array}{l}\text { There may be lack of statistical power to detect non- } \\
\text { linear effects. }\end{array}$ & $(80,81)$ \\
\hline $\begin{array}{l}\text { Non-overlapping } \\
\text { samples (in two- } \\
\text { sample MR) }\end{array}$ & $\begin{array}{l}\text { The strengths of two-sample MR in terms of weak } \\
\text { instrument bias being towards the null and minimising, } \\
\text { overfitting of the data assume that the two samples are } \\
\text { completely independent of each other (i.e., there is no } \\
\text { overlap of participants between the two samples). }\end{array}$ & $\begin{array}{l}\text { In practice, when aggregate data from publicly } \\
\text { available data are used, it may not be possible to } \\
\text { determine whether there is overlap between samples. } \\
\text { This is because many GWASs are conducted on } \\
\text { consortia of many studies. Thus, there is potential for } \\
\text { overlap between some of the studies that contribute to } \\
\text { these consortia (such as the GIANT consortia GWAS of } \\
\text { BMI, waist-hip ratio and height, and the DIAGRAM } \\
\text { consortia GWAS of diabetes). Careful reading of } \\
\text { consortia websites and supplementary material should } \\
\text { be undertaken to determine which studies contribute }\end{array}$ & $\begin{array}{l}(16,17) \\
\text { Figure } 2.6\end{array}$ \\
\hline
\end{tabular}




\begin{tabular}{|c|c|c|c|}
\hline & & $\begin{array}{l}\text { to each of the 'samples' used for the genetic } I V \text {-risk } \\
\text { factor and genetic } I V \text {-outcome samples and, if possible, } \\
\text { sensitivity analyses undertaken with overlapping } \\
\text { studies removed. }\end{array}$ & \\
\hline Overfitting & $\begin{array}{l}\text { This refers to exaggerated (bias away from the null) } \\
\text { results occurring when } M R \text { studies are done within the } \\
\text { same GWAS from which the genetic IVs are selected. }\end{array}$ & $\begin{array}{l}\text { Ideally, selecting genetic IVs from the same study in } \\
\text { which the } M R \text { analysis is being conducted should be } \\
\text { avoided to reduce this overfitting. Using weighted } \\
\text { polygenic risk score (PGRS) in one-sample MR where } \\
\text { the weights of the genetic IV-exposure association are } \\
\text { taken from an independent GWAS minimises bias due } \\
\text { to over fitting. Two-sample MR, where genetic IV- } \\
\text { outcome associations are obtained from an } \\
\text { independent GWAS (i.e., to the GWAS of the exposure) } \\
\text { and there is little or no overlap between the two } \\
\text { samples avoids overfitting. }\end{array}$ & $\begin{array}{l}(30,32) \\
\text { Figure } 2.6\end{array}$ \\
\hline Pleiotropy & $\begin{array}{l}\text { Refers to the potential for genetic variants (including } \\
S N P S \text { ) to associate with multiple phenotypes. }\end{array}$ & $\begin{array}{l}\text { The relevance of a } S N P \text { being pleiotropic to an } M R \\
\text { study is context specific. If the } S N P \text { is pleiotropic } \\
\text { because it influences the outcome only through an }\end{array}$ & $\begin{array}{l}(32,45) \\
\text { Figure } 4.2\end{array}$ \\
\hline
\end{tabular}




\begin{tabular}{|c|c|c|c|}
\hline & & $\begin{array}{l}\text { exposure (trait A), this is known as vertical pleiotropy } \\
\text { and is the exact phenomenon that } M R \text { seeks to detect. } \\
\text { The same variant could associate with another } \\
\text { exposure (trait B) while only influencing the outcome } \\
\text { through (trait A). In the } M R \text { analysis of trait B on the } \\
\text { outcome, the variant is exhibiting horizontal pleiotropy } \\
\text { resulting in violation of the exclusion restriction and, } \\
\text { hence, bias of the } M R \text { effect estimate. }\end{array}$ & \\
\hline $\begin{array}{l}\text { Population } \\
\text { stratification }\end{array}$ & $\begin{array}{l}\text { Population stratification occurs when there exist } \\
\text { population subgroups that experience both different } \\
\text { phenotypic distributions and have different allele } \\
\text { frequencies for genetic variants that might be used in } \\
M R \text {. This can result in spurious (confounded) } \\
\text { associations between genotype and phenotype (i.e., a } \\
\text { trait that might be used as either the risk factor or } \\
\text { outcome in } M R \text { ). }\end{array}$ & $\begin{array}{l}\text { If genetic } I V s \text { used in an } M R \text { study were derived from } \\
G W A S \text { in a population in which there were sub-groups } \\
\text { (e.g., different ethnicities) that differed with respect to } \\
\text { the distributions of both the genetic } I V s \text { and the } \\
\text { phenotype (risk factor of interest in the } M R \text { study), } \\
\text { then the genetic } I V \text {-risk factor association could be } \\
\text { biased by confounding. If the genetic } I V \text {-outcome } \\
\text { associations were determined in studies in which } \\
\text { there were sub-groups with differing genetic and } \\
\text { outcome distributions, the genetic } I V \text {-outcome }\end{array}$ & (30) \\
\hline
\end{tabular}




\begin{tabular}{|c|c|c|c|}
\hline & & $\begin{array}{l}\text { association could be biased by confounding. Most } \\
\text { GWASs and MR studies try to minimise this by } \\
\text { including homogeneous groups of participants (e.g., of } \\
\text { just one ethnicity) and/or by adjusting for genetic } \\
\text { principal components that reflect different sub-groups } \\
\text { within that population sample. }\end{array}$ & \\
\hline $\begin{array}{l}\text { Regression dilution } \\
\text { bias (attenuation by } \\
\text { errors) }\end{array}$ & $\begin{array}{l}\text { Refers to the expected attenuation towards the null of } \\
\text { an association due to random measurement error in a } \\
\text { risk factor. This is particularly likely to occur with risk } \\
\text { factors that have naturally and widely fluctuating } \\
\text { levels, such as blood pressure and (non-fasting) } \\
\text { glucose. }\end{array}$ & $\begin{array}{l}\text { Because genetic variants instrument for lifetime (or } \\
\text { long-term) levels of a risk factor, regression dilution } \\
\text { bias is less likely in } M R \text { studies compared with other } \\
\text { methods, such as multivariable regression, commonly } \\
\text { used with observational data. }\end{array}$ & $(1,30)$ \\
\hline $\begin{array}{l}\text { Relevance (IV1 } \\
\text { assumption) }\end{array}$ & $\begin{array}{l}\text { This is the first of the core } I V \text { assumptions which states } \\
\text { that the } I V \text { must be associated with the risk factor of } \\
\text { interest. }\end{array}$ & $\begin{array}{l}\text { In } M R \text { the aim is to select genetic variants that have } \\
\text { been shown to be robustly associated with the risk } \\
\text { factor of interest. In most } M R \text { studies, this means } \\
\text { genetic variants that are associated with an exposure } \\
\text { at genome-wide significance and replicated in several } \\
\text { independent study samples from the population of }\end{array}$ & $(29,30)$ \\
\hline
\end{tabular}




\begin{tabular}{|c|c|c|c|}
\hline & & $\begin{array}{l}\text { interest. The statistical strength of the genetic } \\
\text { instrument - risk factor association if 'weak' can result } \\
\text { in weak instrument bias. }\end{array}$ & \\
\hline Reverse causality & $\begin{array}{l}\text { The phenomenon where an association in the } \\
\text { direction of a hypothesised causal relation between a } \\
\text { risk factor and outcome is observed but is due (at least } \\
\text { in part) to (potentially undiagnosed or precursors of) } \\
\text { prevalent outcome influencing the risk factor. }\end{array}$ & $\begin{array}{l}\text { In the presence of valid genetic } I V s \text { for both the 'risk } \\
\text { factor' and 'outcome', this can be tested in bidirectional } \\
M R \text {. }\end{array}$ & $\begin{array}{l}(1,30) \\
\text { Figure } 2.1\end{array}$ \\
\hline $\begin{array}{l}\text { Same underlying } \\
\text { population (in two- } \\
\text { sample MR) }\end{array}$ & $\begin{array}{l}\text { It is important that the genetic } I V \text {-risk factor and } \\
\text { genetic } I V \text {-outcome associations in two-sample } M R \text { are } \\
\text { from the same underlying population or, at a } \\
\text { minimum, there is evidence that the gene } I V \text {-risk factor } \\
\text { association is similar in the population used for the } \\
\text { second sample (genetic } I V \text {-outcome association). }\end{array}$ & $\begin{array}{l}\text { Many GWAS that are used to identify genetic } I V S \text { for } M R \\
\text { (and for the genetic } I V \text {-risk factor associations) are } \\
\text { conducted in women and men combined. If these } \\
\text { findings are then combined with genetic } I V \text {-outcome } \\
\text { associations in women only (for example, if the } \\
\text { outcome of interest were breast or ovarian cancer), } \\
\text { the assumption is that the genetic } I V \text {-risk factor } \\
\text { association does not differ between women and men. } \\
\text { Ideally, we would want to have the two samples from } \\
\text { the same underlying population. If this is not possible }\end{array}$ & $\begin{array}{l}(16,17) \\
\text { Figure } 2.6\end{array}$ \\
\hline
\end{tabular}




\begin{tabular}{|c|c|c|c|}
\hline & & $\begin{array}{l}\text { (e.g., because aggregate data being used and the } \\
\text { populations differ in the two samples), some attempt } \\
\text { should be made to find some data that provides } \\
\text { evidence that the genetic } I V \text {-risk factor association is } \\
\text { similar in the population used for the genetic } I V \text { - } \\
\text { outcome association, as in the original GWAS. }\end{array}$ & \\
\hline $\begin{array}{l}\text { Statistical } \\
\text { power/efficiency }\end{array}$ & $\begin{array}{l}\text { In many situations, } M R \text { will be less biased than } \\
\text { conventional multivariable regression (or similar) } \\
\text { approaches to exploring causal associations with } \\
\text { observational data but will have less statistical power. }\end{array}$ & $\begin{array}{l}\text { Large consortia used for } M R \text { studies and the increasing } \\
\text { availability of publicly available summary statistics } \\
\text { from } G W A S \text { that can be used in two-sample } M R \text { can } \\
\text { provide adequate statistical power. }\end{array}$ & $(32,82)$ \\
\hline Vertical Pleiotropy & $\begin{array}{l}\text { Also known as "spurious" or "false" pleiotropy. This is } \\
\text { when a genetic variant affects other traits (which } \\
\text { influence the outcome) via its effect on the exposure. }\end{array}$ & $\begin{array}{l}\text { This is the very phenomenon that } M R \text { seeks to detect } \\
\text { (i.e., the chain of traits to the outcome is what gives } \\
\text { rise to an unbiased non-null causal effect estimate). }\end{array}$ & $\begin{array}{l}(32,45) \\
\text { Figure } 4.2\end{array}$ \\
\hline Weak instrument bias & $\begin{array}{l}\text { Instrument strength is determined by the magnitude } \\
\text { and precision of association of the genetic IVs with the } \\
\text { risk factor of interest. }\end{array}$ & $\begin{array}{l}\text { The } \mathrm{R}^{2} \text { and F-statistic for the association of the genetic } \\
I V \text { with the risk factor provide an indication of } \\
\text { instrument strength (the higher the value of both, the } \\
\text { stronger the instrument and the greater statistical } \\
\text { power in } M R \text { analyses). For reference, genetic } I V s \text { were }\end{array}$ & $(30,32)$ \\
\hline
\end{tabular}




\begin{tabular}{|c|c|c|c|}
\hline & & $\begin{array}{l}\text { traditionally considered to be sufficient if the } \\
\text { corresponding F-statistic was }>10 \text {. In one-sample } M R \text {, } \\
\text { weak instruments tend to bias towards the } \\
\text { confounded risk factor-outcome association; whereas, } \\
\text { in two-sample MR (with non-overlapping samples) the } \\
\text { bias is expected to be towards the null. }\end{array}$ & \\
\hline Winner's curse & $\begin{array}{l}\text { This refers to the phenomenon that the 'first' } \\
\text { (discovery) results for an association tend to be } \\
\text { exaggerated (away from the null), with replication } \\
\text { studies tending to be more modest. }\end{array}$ & $\begin{array}{l}\text { In } M R \text {, if the genetic } I V \text {-risk factor association is based } \\
\text { on results (or weights) of the discovery GWAS (or a } \\
\text { single study) rather than combined discovery and } \\
\text { replication results or replication results only, then the } \\
I V \text {-risk factor association may be exaggerated. As this } \\
\text { is the denominator of the Wald ratio (used to estimate } \\
\text { the } M R \text { effect), the } M R \text { result would tend to be biased } \\
\text { towards the null. This may be particularly likely in } \\
\text { large biobank studies in which both the primary } G W A S \\
\text { and one-sample } M R \text { analyses are undertaken in the } \\
\text { same sample. }\end{array}$ & $(32,83)$ \\
\hline
\end{tabular}


Figure 4.1: Collider bias

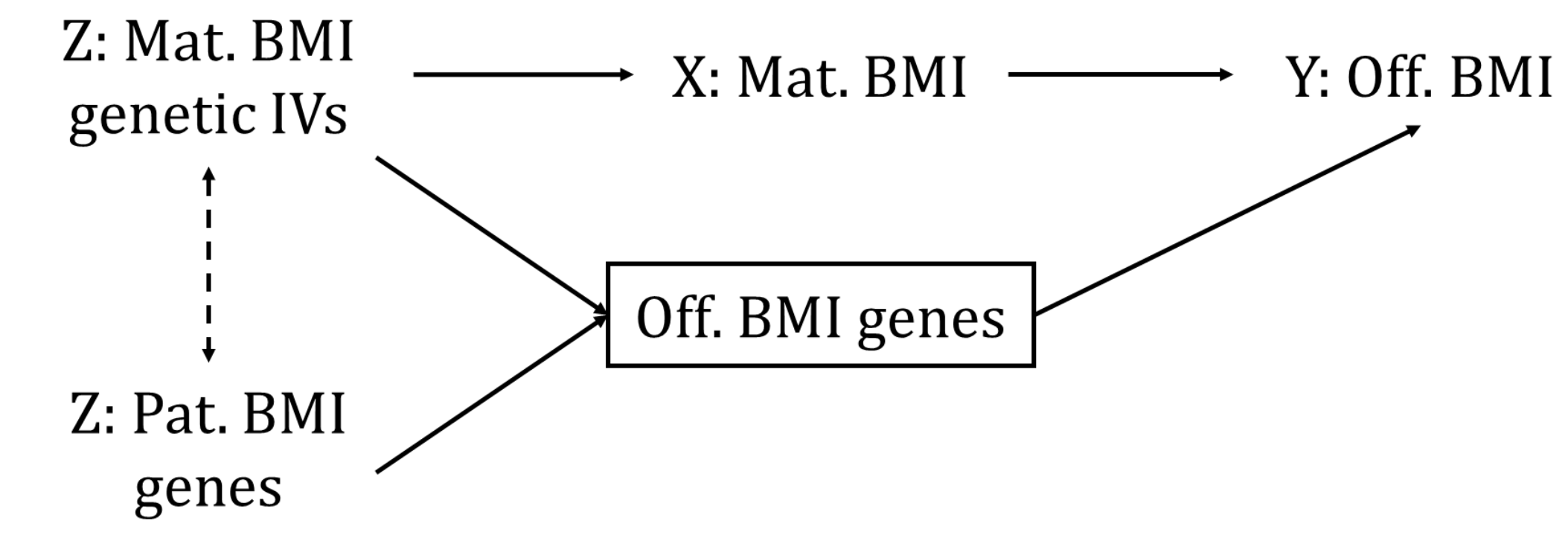

This figure illustrates collider bias in an MR study exploring the effect of maternal pregnancy body mass index (X: Mat. BMI) on offspring body mass index in later adult life (Y: Off. BMI). There is a clear violation of the assumption that the genetic instrumental variable (Z: Mat. BMI genetic IVs) is not related to the outcome (Y) other than via the exposure (X). It is clear that maternal BMI genetic IVs will influence offspring BMI genes (Off. BMI genes), which in turn will influence offspring BMI. This path can be blocked by adjusting for offspring genetic variants (this is illustrated by the box around offspring BMI genes). However, both maternal and paternal BMI genes (Z: Pat. BMI genes) 'collide' on offspring BMI genes and this generates a spurious association between maternal and paternal BMI genes. As only maternal and paternal BMI genes determine offspring BMI genes once we condition maternal genes on offspring genes, we know to some extent what paternal genotype is (e.g., if mother is a homozygote for a BMI increasing allele at a gene and offspring is heterozygous at the same gene, then dad must be heterozygous or homozygous for the alternative (not BMI increasing) allele). If it is not possible to condition on paternal genotype (which is often the case) and paternal BMI genes directly influence offspring BMI, this collider bias will bias the MR analysis of maternal pregnancy BMI on subsequent offspring BMI (26). 
Figure 4.2: Vertical and Horizontal Pleiotropy. Adapted from Hemani et al. (84) and Holmes et al. (85).

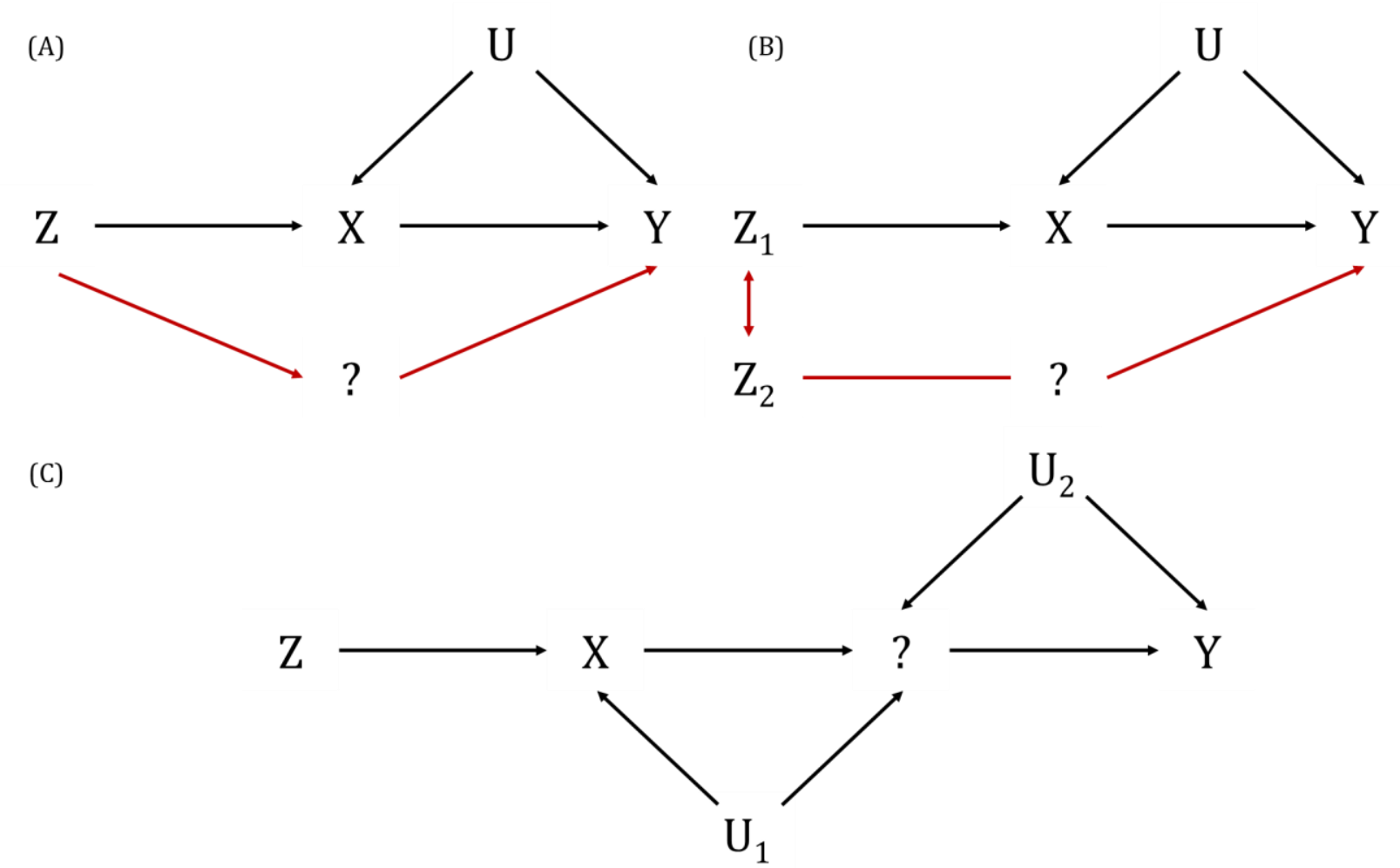

(A) Classic horizontal pleiotropy, whereby the instrument (Z) for the exposure of interest (X) is independently associated with the outcome (Y) either directly or indirectly through other trait(s) - denoted "?". Here, this would violate the third assumption of MR and would bias results from an MR study. (B) Indirect horizontal pleiotropy, whereby another $S N P\left(Z_{2}\right)$ in linkage disequilibrium $(L D)$ with the instrument $\left(Z_{1}\right)$ for the exposure of interest $(X)$ is associated with the outcome $(Y)$ and, due to this correlation between SNPS, the instrument is therefore not independent of the outcome of interest. This is another reason to use independent genetic variants as instruments in an MR analysis and to have some biological knowledge about the mechanisms by which the SNPs are associated with the exposure. (C) A depiction of vertical pleiotropy, whereby the genetic instrument $(Z)$ for the exposure $(X)$ is associated with other trait(s) - denoted "?" - however, this reflects the downstream effects of the exposure that is likely on the causal pathway linking the exposure to the outcome (Y). This is the very essence of MR and is not something that needs to be accounted for in analyses. Measured and unmeasured confounders in all diagrams as represented by " $U^{\prime \prime}$, " $U_{1}$ " and " $U_{2}$ ". 


\section{Chapter 5: Key statistical methods used in MR for a standard one-sample context}

\begin{tabular}{|c|c|c|c|}
\hline Term & Brief definition & $\begin{array}{l}\text { Summary of assumptions and } \\
\text { restrictions of use in different } \\
\text { types of MR / with number of } \\
\text { genetic IVs }\end{array}$ & $\begin{array}{l}\text { Useful journal reference(s) or references to } \\
\text { figures shown later in the chapter, if } \\
\text { appropriate }\end{array}$ \\
\hline $\begin{array}{l}\text { Generalized Method of } \\
\text { Moments (GMM) } \\
\text { estimator }\end{array}$ & $\begin{array}{l}\text { Generalized Method of Moments } \\
\text { (GMM) is an estimation technique that } \\
\text { is helpful where the distribution of the } \\
\text { data maybe unknown and therefore } \\
\text { alternative estimation techniques such } \\
\text { as maximum likelihood are not } \\
\text { applicable. For a given model, we } \\
\text { specify a certain number of moment } \\
\text { conditions, which are functions of the } \\
\text { model parameters and the data, such } \\
\text { that their expectation is zero at the } \\
\text { parameters' true values. The GMM } \\
\text { estimator of a linear } I V \text { model has been }\end{array}$ & $\begin{array}{l}\text { In the context of } I V \text { estimation, we } \\
\text { usually specify } 1 \text { moment condition } \\
\text { per } I V \text {. The GMM method then } \\
\text { minimizes a certain norm of the } \\
\text { sample averages of the moment } \\
\text { conditions. For identification we } \\
\text { require at least as many IVs as } \\
\text { there are parameters to be } \\
\text { estimated. For binary outcomes, } \\
\text { GMM estimation of structural mean } \\
\text { models can be used to estimate } \\
\text { parameters such as the causal risk }\end{array}$ & $(86,87)$ \\
\hline
\end{tabular}




\begin{tabular}{|c|c|c|c|}
\hline & $\begin{array}{l}\text { applied to individual-level data in } \\
\text { Economics since the } 1980 \text { s. }\end{array}$ & $\begin{array}{l}\text { ratio in } M R \text { studies using } \\
\text { individual-level data. }\end{array}$ & \\
\hline $\begin{array}{l}\text { MR with a time-to- } \\
\text { event outcome }\end{array}$ & $\begin{array}{l}\text { Two-stage approach for causal } \\
\text { estimation with time-to-event } \\
\text { outcomes, where } 2^{\text {nd }} \text { stage regression is } \\
\text { substituted with either a Cox } \\
\text { proportional hazard, or additive hazard } \\
\text { regression. }\end{array}$ & $\begin{array}{l}\text { Genetic variants must satisfy the } I V \\
\text { assumptions. Outcome must be } \\
\text { rare for Cox model to be valid. } \\
\text { Censoring must be independent of } \\
\text { mortality. Model specification must } \\
\text { be correct (i.e., additive hazard). } \\
\text { confounding acts linearly on } \\
\text { additive hazard scale. However, } \\
\text { there is no consensus about the } \\
\text { gold standard way of dealing with } \\
\text { time-to-event data within an } M R \\
\text { context. }\end{array}$ & $(90,91)$ \\
\hline $\begin{array}{l}\text { Non-parametric } \\
\text { methods with bounds of } \\
\text { causal effect }\end{array}$ & $\begin{array}{l}\text { A non-parametric method that } \\
\text { estimates upper and lower bounds for } \\
\text { an } M R \text { causal effect. The bounds are not } \\
\text { the same as confidence intervals they }\end{array}$ & $\begin{array}{l}\text { Genetic variants must satisfy the } I V \\
\text { assumptions. It does not require } \\
\text { any of the additional } I V \\
\text { assumptions. This method can only }\end{array}$ & $(88,89)$ \\
\hline
\end{tabular}




\begin{tabular}{|c|c|c|c|}
\hline & $\begin{array}{l}\text { reflect the upper and lower limits of an } \\
\text { estimated distribution of causal effects. }\end{array}$ & $\begin{array}{l}\text { be used in the situation of binary } \\
\text { (or categorical with few levels) risk } \\
\text { factor, } I V \text { and outcome. A method } \\
\text { for implementing these in Stata has } \\
\text { been developed. }\end{array}$ & \\
\hline $\begin{array}{l}\text { Polygenic risk score } \\
\text { approach }\end{array}$ & $\begin{array}{l}\text { A method which combines multiple } \\
\text { genetic IVs into a single univariate } \\
\text { score, which is then used as a single } I V \text {. }\end{array}$ & $\begin{array}{l}\text { The univariate score must be a } \\
\text { valid instrument. More robust to } \\
\text { weak instrument bias than two- } \\
\text { stage least squares (TSLS). Hard to } \\
\text { test for instrument validity. }\end{array}$ & (92) \\
\hline $\begin{array}{l}\text { Semi-parametric } \\
\text { structural mean model } \\
\text { (SMMs) for binary } \\
\text { outcomes }\end{array}$ & $\begin{array}{l}\text { SMM approach to } M R \text { that avoids } \\
\text { having to specify a first stage } \\
\text { regression model. }\end{array}$ & $\begin{array}{l}\text { Genetic variants must satisfy the } I V \\
\text { assumptions. No need to specify } \\
\text { first stage gene-exposure } \\
\text { association model. Can be extended } \\
\text { to handle case control data. }\end{array}$ & (47) \\
\hline $\begin{array}{l}\text { Two-stage least squares } \\
\text { (TSLS) }\end{array}$ & $\begin{array}{l}\text { The canonical method to estimate the } \\
\text { causal effect of a continuous exposure } \\
\text { on a continuous outcome using an } I V \text {. }\end{array}$ & $\begin{array}{l}\text { Genetic variants must satisfy the } I V \\
\text { assumptions. Gene-outcome model } \\
\text { must be correctly specified. }\end{array}$ & (93) \\
\hline
\end{tabular}




\begin{tabular}{|l|l|l|l|}
\hline TSLS with binary & $\begin{array}{l}\text { Ad-hoc method for causal estimation } \\
\text { outcome }\end{array}$ & $\begin{array}{l}\text { Genetic variants must satisfy the } I V \\
\text { with binary outcomes, where } 2^{\text {nd }} \text { stage } \\
\text { regression is substituted with a logistic } \\
\text { assumptions. Genes each exert a }\end{array}$ & small effect on the exposure in \\
regression. & order to approximately identify the \\
& same causal effect. Non- \\
& collapsibility of odds ratio means \\
& that population average rather than \\
& individual-level causal effects are & estimated. \\
\end{tabular}




\section{Chapter 6: Pleiotropy-robust one-sample MR methods}

\begin{tabular}{|c|c|c|c|}
\hline Term & Brief definition & $\begin{array}{l}\text { Summary of assumptions and } \\
\text { restrictions of use in different types of } \\
\text { MR / with number of genetic IVs }\end{array}$ & $\begin{array}{l}\text { Useful journal reference(s) } \\
\text { or references to figures } \\
\text { shown later in the chapter, } \\
\text { if appropriate }\end{array}$ \\
\hline MR GENIUS & $\begin{array}{l}\text { MR G-Estimation under No Interaction with } \\
\text { Unmeasured Selection. }\end{array}$ & $\begin{array}{l}\text { Exploits the assumption that a genetic } \\
\text { variant is a valid instrument with respect } \\
\text { to altering the variance rather than the } \\
\text { mean. Genetic instrument must strongly } \\
\text { affect the variance. }\end{array}$ & (94) \\
\hline MR GxE & $\begin{array}{l}\text { MR-GxE is an extension to TSLS that exploits } \\
\text { gene-covariate interactions to test for correct for } \\
\text { invalid instruments within a linear interaction } \\
\text { model framework. }\end{array}$ & $\begin{array}{l}\text { Requires a strong gene-environment } \\
\text { interaction and the pleiotropic effect to be } \\
\text { constant across covariate subgroups. }\end{array}$ & $(18,95,96)$ \\
\hline PRMR & $\begin{array}{l}\text { Pleiotropy robust } M R \text { estimates the causal effect } \\
\text { in the presence of pleiotropy by identifying a } \\
\text { patient subgroup for which the genetic variant } \\
\text { does not affect the exposure. The pleiotropic }\end{array}$ & $\begin{array}{l}\text { Requires a perfect 'no-relevance } \\
\text { subgroup'. The pleiotropic effect must be } \\
\text { constant across covariate subgroups. }\end{array}$ & (21) \\
\hline
\end{tabular}




\begin{tabular}{|c|c|c|c|}
\hline & $\begin{array}{l}\text { effect estimated from this subgroup is then } \\
\text { subtracted as an offset from the TSLS estimate. }\end{array}$ & & \\
\hline SISVIVE & $\begin{array}{l}\text { Some Invalid Some Valid Instrumental Variable } \\
\text { Estimation (SISVIVE). An extension to the TSLS } \\
\text { procedure which incorporates LASSO } \\
\text { penalization. }\end{array}$ & $\begin{array}{l}\text { Can identify consistent estimates of the } \\
\text { causal effect if the majority of SNPs are } \\
\text { valid instruments. Currently, only } \\
\text { developed for continuously measured } \\
\text { outcomes. }\end{array}$ & (20) \\
\hline $\begin{array}{l}\text { Two-stage Hard } \\
\text { Thresholding (TSHT) with } \\
\text { voting }\end{array}$ & $\begin{array}{l}\text { TSLS applied to a subset of SNPS which are } \\
\text { judged to be estimating the same causal effect. }\end{array}$ & $\begin{array}{l}\text { Assumes that valid SNPS form the largest } \\
\text { set of SNPS which identify the same (true) } \\
\text { causal effect. Requires strong genetic } \\
\text { instruments. }\end{array}$ & (19) \\
\hline
\end{tabular}


Chapter 7: Two-sample MR methods Note: these methods were mostly developed for use with summary GWAS data

\begin{tabular}{|c|c|c|c|}
\hline Term & Brief definition & $\begin{array}{l}\text { Summary of assumptions and } \\
\text { restrictions of use in different types of } \\
\text { MR / with number of genetic IVs }\end{array}$ & $\begin{array}{l}\text { Useful journal reference(s) } \\
\text { or references to figures } \\
\text { shown later in the chapter, } \\
\text { if appropriate }\end{array}$ \\
\hline $\begin{array}{l}\text { Inverse variance weighted } \\
\text { (IVW) fixed effect estimate }\end{array}$ & $\begin{array}{l}\text { Combines Wald ratios (or Ratio estimates) } \\
\text { together in fixed effect meta-analysis, where the } \\
\text { weight of each ratio is the inverse of the variance } \\
\text { of the SNP-outcome association. Here, each } \\
\text { instrumenting SNP is treated as an independent } \\
\text { 'study', and the Wald ratios estimated for each } \\
\text { SNP are meta-analysed under a fixed effects } \\
\text { model. }\end{array}$ & $\begin{array}{l}\text { The fixed effects meta-analysis assumes } \\
\text { that the only source of differences } \\
\text { between estimates across the studies is } \\
\text { due to sampling variation (i.e., the true } \\
\text { causal effect estimate is identical across all } \\
\text { studies). In the MR context this translates } \\
\text { to each } S N P \text { exhibiting no horizontal } \\
\text { pleiotropy. Genes must be valid } \\
\text { instruments. If all } S N P S \text { exhibit horizontal } \\
\text { pleiotropy, then the effect estimate is } \\
\text { asymptotically unbiased, but the standard } \\
\text { error will be overly precise. Uses weights } \\
\text { that assume the } S N P \text {-exposure association }\end{array}$ & $(15,97)$ \\
\hline
\end{tabular}




\begin{tabular}{|c|c|c|c|}
\hline & & $\begin{array}{l}\text { is known, rather than estimated, with no } \\
\text { measurement error (i.e., known as the } \\
\text { NOME assumption). Causal effect } \\
\text { estimates from the IVW approach exhibit } \\
\text { weak instrument bias whenever SNPS used } \\
\text { as IVs violate the NOME assumption, which } \\
\text { can be measured using the F-statistic with } \\
\text { IVW methods. }\end{array}$ & \\
\hline $\begin{array}{l}\text { Maximum likelihood-based } \\
\text { MR }\end{array}$ & $\begin{array}{l}\text { Similar IVW (fixed effect) but approached using a } \\
\text { maximum likelihood method where the genetic } \\
\text { effects on the exposure and outcome are } \\
\text { modelled directly as a bivariate normal } \\
\text { distribution. }\end{array}$ & $\begin{array}{l}\text { The method requires a term which } \\
\text { represents the proportion of sample } \\
\text { overlap between the exposure and } \\
\text { outcome datasets. Requires an iterative } \\
\text { estimating procedure that can occasionally } \\
\text { fail to converge. This method is largely } \\
\text { equivalent to } I V W \text { and is no longer } \\
\text { commonly used. }\end{array}$ & (92) \\
\hline Summary MR (SMR) & $\begin{array}{l}\text { A method often applied to } M R \text { estimates which is } \\
\text { related to the Wald ratio and often applied in }\end{array}$ & See Wald ratio. & (98) \\
\hline
\end{tabular}




\begin{tabular}{|c|c|c|c|}
\hline & $\begin{array}{l}\text { analysis of gene expression on complex traits } \\
\text { and used in conjunction with the HEIDI method. }\end{array}$ & & \\
\hline Unweighted regression & $\begin{array}{l}\text { Similar to the IVW (fixed effects) in concept, but } \\
\text { all SNPs are weighted equally. }\end{array}$ & $\begin{array}{l}\text { The intention of the method is that in } \\
\text { some cases a GWAS will return one } \\
\text { extremely large effect on the exposure and } \\
\text { many small effects, and that single large } \\
\text { effect will dominate the analysis. The } \\
\text { method is seldom used in practice though, } \\
\text { as alternative approaches such as leave- } \\
\text { one-out analysis can be used for sensitivity } \\
\text { instead. }\end{array}$ & \\
\hline $\begin{array}{l}\text { Wald ratio (or Ratio) } \\
\text { estimate }\end{array}$ & $\begin{array}{l}\text { Causal estimate obtained for a single genetic } \\
\text { variant by dividing its gene-outcome association } \\
\text { by its gene-exposure association. }\end{array}$ & $\begin{array}{l}\text { Genetic variants must satisfy the IV } \\
\text { assumptions. Equivalent to TSLS (and its } \\
\text { approximate binary/time-to-event } \\
\text { outcome) variants with one instrument. }\end{array}$ & (99) \\
\hline
\end{tabular}


Chapter 8: Pleiotropy-robust MR methods for a two-sample MR context Note: these methods were mostly developed for use with summary GWAS data

\begin{tabular}{|c|c|c|c|}
\hline Term & Brief definition & $\begin{array}{l}\text { Summary of assumptions and } \\
\text { restrictions of use in different types of } \\
\text { MR / with number of genetic IVs }\end{array}$ & $\begin{array}{l}\text { Useful journal reference(s) } \\
\text { or references to figures } \\
\text { shown later in the chapter, } \\
\text { if appropriate }\end{array}$ \\
\hline $\begin{array}{l}\text { Generalized summary MR } \\
\text { (GSMR) }\end{array}$ & $\begin{array}{l}\text { The name given to a method implemented in a } \\
\text { particular piece of software which is similar to } \\
\text { standard IVW but also allows for correlation } \\
\text { between variants and seeks to remove outliers. }\end{array}$ & $\begin{array}{l}\text { The 'MendelianRandomization' package } \\
\text { also provides utility for including the } L D \\
\text { matrix to provide overly precise standard } \\
\text { errors if instruments are correlated. } \\
\text { Performance of the method is dependent } \\
\text { on accurate estimation of the } L D \text { matrix for } \\
\text { the samples being used. }\end{array}$ & $(100)$ \\
\hline IVW (random effects) & $\begin{array}{l}\text { Combines Wald ratios (or Ratio estimates) } \\
\text { together in an inverse variance weighted meta- } \\
\text { analysis, adjusting for heterogeneity. }\end{array}$ & $\begin{array}{l}\text { All genetic IVs can be invalid due to } \\
\text { pleiotropy as long as the pleiotropy is } \\
\text { balanced (it has a zero mean and satisfies } \\
\text { the Instrument Strength Independent of } \\
\text { Direct Effect - InSIDE - assumption). This } \\
\text { means that the association of genetic }\end{array}$ & (101) \\
\hline
\end{tabular}




\begin{tabular}{|c|c|c|c|}
\hline & & $\begin{array}{l}\text { instrument with exposure of interest } \\
\text { should not be associated with the path } \\
\text { between instrument and outcome that } \\
\text { does not go via the exposure of interest. } \\
\text { Asymptotically equivalent to TSLS with } \\
\text { uncorrelated variants. }\end{array}$ & \\
\hline Mode-based estimate & $\begin{array}{l}\text { Defined as the mode of an inverse variance } \\
\text { weighted empirical density function of the Wald } \\
\text { ratio (or Ratio estimates). }\end{array}$ & $\begin{array}{l}\text { Requires that the largest subset of } \\
\text { instruments which identify the same } \\
\text { causal effect to be valid instruments. }\end{array}$ & $(102)$ \\
\hline $\begin{array}{l}\text { MR-Egger regression and } \\
\text { extensions }\end{array}$ & $\begin{array}{l}\text { Combines Wald ratio (or Ratio estimates) } \\
\text { together into a meta-regression (with an } \\
\text { intercept and slope parameter) to estimate the } \\
\text { causal effect adjusted for any directional } \\
\text { pleiotropy. }\end{array}$ & $\begin{array}{l}\text { All SNPS can be invalid due to pleiotropy as } \\
\text { long as the pleiotropy satisfies the InSIDE } \\
\text { assumption. Can be implemented in a } \\
\text { Bayesian framework. Standard } \\
\text { implementation requires gene-exposure } \\
\text { associations to be orientated in positive } \\
\text { direction. Radial MR formulation avoids } \\
\text { this step. The intercept of a MR-Egger } \\
\text { regression provides an indication of }\end{array}$ & $(14,103-105)$ \\
\hline
\end{tabular}




\begin{tabular}{|c|c|c|c|}
\hline & & $\begin{array}{l}\text { pleiotropy when it is not null. Similar to } \\
\text { IVW methods, the NOME assumption still } \\
\text { holds and, if violated, there may be weak } \\
\text { instrument bias. This can be tested with } \\
\text { the I² statistic with the MR-Egger method. }\end{array}$ & \\
\hline MR-RAPS & $\begin{array}{l}\text { MR using a Robust Adjusted Profile Score. } \\
\text { Maximises the profile likelihood of the Wald } \\
\text { ratio (or Ratio estimates), accounting for weak } \\
\text { instrument bias, pleiotropy and extreme outliers. }\end{array}$ & $\begin{array}{l}\text { All SNPS can be invalid due to pleiotropy as } \\
\text { long as the pleiotropy is balanced. }\end{array}$ & (106) \\
\hline $\begin{array}{l}\text { Multivariable MR (MVMR) } \\
\text { and extensions }\end{array}$ & $\begin{array}{l}\text { Multivariable MR extension of the IVW approach } \\
\text { applied to the summary data context. Used to } \\
\text { learn about the causal effect of two or more } \\
\text { exposures on an outcome. }\end{array}$ & $\begin{array}{l}\text { All genetic IVs must be associated with at } \\
\text { least one exposure. All genetic IVs can be } \\
\text { invalid instruments due to pleiotropy as } \\
\text { long as the pleiotropy is balanced. Method } \\
\text { can be combined with MR-Egger } \\
\text { regression to allow for directional } \\
\text { pleiotropy. }\end{array}$ & $(107,108)$ \\
\hline
\end{tabular}




\begin{tabular}{|l|l|l|l|}
\hline Weighted median & $\begin{array}{l}\text { Defined as the } 50^{\text {th }} \text { percentile of an inverse } \\
\text { variance weighted empirical density function of } \\
\text { the Wald ratio (or Ratio estimates). }\end{array}$ & $\begin{array}{l}\text { Requires that at least 50\% of the weight in } \\
\text { the analysis stems from variants that are } \\
\text { valid instruments. }\end{array}$ \\
\hline
\end{tabular}


Chapter 9: Model and instrument selection and averaging approached for a two-sample MR context Note: these methods were mostly developed for use with summary GWAS data

\begin{tabular}{|c|c|c|c|}
\hline Term & Brief definition & $\begin{array}{l}\text { Summary of assumptions and } \\
\text { restrictions of use in different types of } \\
\text { MR / with number of genetic IVs }\end{array}$ & $\begin{array}{l}\text { Useful journal reference(s) } \\
\text { or references to figures } \\
\text { shown later in the chapter, } \\
\text { if appropriate }\end{array}$ \\
\hline $\begin{array}{l}\text { Bayesian model averaging for } \\
\text { IVW and MR-Egger }\end{array}$ & $\begin{array}{l}\text { Uses Bayesian Model Averaging to infer the } \\
\text { posterior probability that the IVW or MR-Egger } \\
\text { regression models (with or without } \\
\text { heterogeneity) is the true data generating model. }\end{array}$ & $\begin{array}{l}\text { Requires the specification of priors for the } \\
\text { regression model parameters and/or the } \\
\text { probability that each model is 'true'. }\end{array}$ & (109) \\
\hline MR-MoE & $\begin{array}{l}\text { MR Mixture of Experts uses machine learning to } \\
\text { choose the best performing model out of } 28 \\
\text { different pleiotropy robust estimation methods. }\end{array}$ & $\begin{array}{l}\text { Based on meta-learning, in which } \\
\text { simulations are used to train a machine } \\
\text { which selects the method most likely to } \\
\text { return a reliable } M R \text { estimate. }\end{array}$ & $(110)$ \\
\hline $\begin{array}{l}\text { Rucker framework for IVW } \\
\text { and MR-Egger }\end{array}$ & $\begin{array}{l}\text { Uses goodness-of-fit heterogeneity statistics to } \\
\text { decide whether the IVW or MR-Egger regression } \\
\text { models (with or without heterogeneity) is best } \\
\text { supported by the data. }\end{array}$ & $\begin{array}{l}\text { Requires p-value thresholds to be } \\
\text { specified to guide model choice. }\end{array}$ & (101) \\
\hline
\end{tabular}




\begin{tabular}{|c|c|c|c|}
\hline Steiger filtering & $\begin{array}{l}\text { Large-scale GWAS have the power to detect very } \\
\text { small effects. Steiger filtering is a method for } \\
\text { selecting valid genetic IVs from very large GWAS } \\
\text { with statistical power to identify genetic variants } \\
\text { that are related to the trait of interest at a } \\
\text { genome-wide significance threshold because it is } \\
\text { downstream of many other traits that the genetic } \\
\text { variant influences. For example, a sufficiently } \\
\text { large GWAS of a biomarker (A) may identify } \\
\text { numerous genetic variants that influence } \\
\text { another biomarker (B) because A is influenced } \\
\text { by B. }\end{array}$ & $\begin{array}{l}\text { If those variants are included in an } M R \\
\text { study of the effect of A on B without } \\
\text { knowledge of their biology (as is typical } \\
\text { from GWAS results), the result could } \\
\text { (erroneously) suggest that A causes B } \\
\text { (when the opposite is true). These reverse } \\
\text { causal } I V s \text { will bias the } M R \text { estimate. In } \\
\text { these situations, Steiger filtering uses a } \\
\text { statistical test to identify the stronger of } \\
\text { bidirectional effects (e.g., A on B or B on A) } \\
\text { to select valid } I V s \text { from very large GWAS } \\
\text { that can be used in } M R \text {. Steiger filtering } \\
\text { assumes that a valid } I V \text { should explain } \\
\text { more variance in the exposure than the } \\
\text { outcome and removes those } g e n e t i c \\
\text { variants that do not satisfy this criterion. If } \\
\text { A has much more measurement error than } \\
\text { the variance explained by the } S N P\end{array}$ & $(110,111)$ \\
\hline
\end{tabular}




\begin{tabular}{|l|l|l|}
\hline & $\begin{array}{l}\text { on A might be smaller than on B even } \\
\text { though it primarily influences A. Some } \\
\text { patterns of confounding can also lead to } \\
\text { this problem. }\end{array}$ \\
\hline
\end{tabular}


Chapter 10: Heterogeneity and outlier-detection methods for a two-sample MR context Note: these methods were mostly developed for use with summary GWAS data

\begin{tabular}{|c|c|c|c|}
\hline Term & Brief definition & $\begin{array}{l}\text { Summary of assumptions and } \\
\text { restrictions of use in different types of } \\
\text { MR / with number of genetic IVs }\end{array}$ & $\begin{array}{l}\text { Useful journal reference(s) } \\
\text { or references to figures } \\
\text { shown later in the chapter, } \\
\text { if appropriate }\end{array}$ \\
\hline Cochran's Q statistic & Heterogeneity statistic for $I V W$ model. & $\begin{array}{l}\text { If Q much larger than its degrees of } \\
\text { freedom (No. of } I V \text { s minus 1), this provides } \\
\text { evidence for heterogeneity and invalid } \\
\text { instruments. Assumes genetic IVs are } \\
\text { uncorrelated. Individual contribution of } \\
\text { each } I V \text { to Q can be used to detect } \\
\text { individual invalid } I V \text { s. An extended version } \\
\text { of Q statistic necessary when genetic } \\
\text { instruments are weak. }\end{array}$ & $(15,112)$ \\
\hline $\begin{array}{l}\text { HEIDI (heterogeneity in } \\
\text { dependent instruments) }\end{array}$ & $\begin{array}{l}\text { A method which seeks to address if many SNPS } \\
\text { in a single region give Wald ratio (or Ratio } \\
\text { estimates) estimates that are more different }\end{array}$ & $\begin{array}{l}\text { This is essentially a genetic colocalization } \\
\text { method, and a number of similar methods } \\
\text { exist (e.g., R/coloc and S-predixscan). }\end{array}$ & $(62,63,98)$ \\
\hline
\end{tabular}




\begin{tabular}{|c|c|c|c|}
\hline & $\begin{array}{l}\text { from each other than expected by chance under } \\
\text { the assumption that there is a single causal } \\
\text { variant and each } S N P \text { only exhibits an effect due } \\
\text { to } L D \text { with the causal } S N P \text {. }\end{array}$ & & \\
\hline MR-PRESSO & $\begin{array}{l}\text { This is an extension to } I V W \text {, which attempts to } \\
\text { perform the same form of outlier removal as in } \\
\text { GSMR and Radial MR. }\end{array}$ & $\begin{array}{l}\text { Genetic variants are removed based on } \\
\text { their contributions to heterogeneity. It is } \\
\text { achieved through a simulation approach. } \\
\text { See notes on outlier removal. }\end{array}$ & (113) \\
\hline $\begin{array}{l}\text { MR-TRYX (Treasure your } \\
\text { exceptions) }\end{array}$ & $\begin{array}{l}\text { A framework for exploiting horizontal pleiotropy. } \\
\text { If a } S N P \text { appears to be an outlier in an } M R \\
\text { analysis, then it is hypothesised that it is } \\
\text { additionally associating with the outcome } \\
\text { through another trait. Searching through GWAS } \\
\text { databases to find candidate traits, then } \\
\text { modelling the original exposure-outcome } \\
\text { association accounting for the candidate traits } \\
\text { allows a) detection of new putative risk factors }\end{array}$ & $\begin{array}{l}\text { Depends on the ability to accurately } \\
\text { estimate the effect estimates on the path } \\
\text { through candidate traits. Automated using } \\
\text { available GWAS databases such as } M R \text { - } \\
\text { Base, which do not have complete } \\
\text { coverage of the human phenome and } \\
\text { therefore unlikely to be able to completely } \\
\text { account for the heterogeneity. }\end{array}$ & (114) \\
\hline
\end{tabular}




\begin{tabular}{|c|c|c|c|}
\hline & $\begin{array}{l}\text { and b) reducing heterogeneity and/or bias in the } \\
\text { original estimate. }\end{array}$ & & \\
\hline $\begin{array}{l}\text { Radial MR (MR pleiotropy } \\
\text { residual sum and outlier) }\end{array}$ & $\begin{array}{l}\text { Similar to } I V W \text { but uses a simulation-based } \\
\text { approach to detect outlying variants and flags } \\
\text { them for removal in order to re-estimate the } \\
\text { original exposure-outcome relationship. It has } \\
\text { been shown that this outlier detection } \\
\text { framework is closely related to the analytical } \\
\text { approach of applying } I V W \text { with so-called } \\
\text { "modified second order weights". }\end{array}$ & $\begin{array}{l}\text { Outlier removal methods can effectively } \\
\text { reduce bias in } M R \text { estimates, but caution } \\
\text { must be made because they will } \\
\text { necessarily reduce the standard error and } \\
\text { could lead to over-fitting. Other outlier } \\
\text { removal methods have also been } \\
\text { implemented elsewhere in GSMR and } \\
\text { RadialMR. }\end{array}$ & $(104)$ \\
\hline
\end{tabular}




\section{Chapter 11: Useful software and tools}

\begin{tabular}{|c|c|c|}
\hline Name & Link & $\begin{array}{l}\text { Useful journal reference(s) or references to } \\
\text { figures shown later in the chapter, if } \\
\text { appropriate }\end{array}$ \\
\hline GSMR & http://cnsgenomics.com/software/gsmr/ & $\begin{array}{l}\text { An R-package that implements the Generalized } \\
\text { summary MR (GSMR) method to test for } \\
\text { putative causal association between a risk } \\
\text { factor and a disease using summary-level data } \\
\text { from GWAS (100). }\end{array}$ \\
\hline LD Hub & $\begin{array}{l}\text { https://github.com/bulik/ldsc } \\
\underline{\text { http://ldsc.broadinstitute.org/ldhub/ }}\end{array}$ & $\begin{array}{l}\text { A database of summary-level GWAS results and } \\
\text { a web interface for undertaking } L D \text { score } \\
\text { regression - a method that estimates the } S N P \\
\text { heritability of complex traits and diseases, } \\
\text { partitions this heritability into functional } \\
\text { categories, and estimates the genetic } \\
\text { correlation between different phenotypes } \\
\text { (115). }\end{array}$ \\
\hline
\end{tabular}




\begin{tabular}{|c|c|c|}
\hline MendelianRandomization & https://cran.r-project.org/web/packages/MendelianRandomization/index.html & $\begin{array}{l}\text { R-package to perform } M R \text { analyses with } \\
\text { summary (aggregate) data, which requires } \\
\text { summary-level data on the associations of } \\
\text { genetic variants with the exposure and } \\
\text { outcome to be obtained from large consortia by } \\
\text { the user (116). }\end{array}$ \\
\hline $\begin{array}{l}\text { MR-Base and } \\
\text { TwoSampleMR }\end{array}$ & $\begin{array}{l}\text { http://www.mrbase.org/ } \\
\text { https://github.com/MRCIEU/TwoSampleMR }\end{array}$ & $\begin{array}{l}\text { A database and analytical platform for } \\
\text { undertaking two-sample MR using summary } \\
\text { GWAS data. It runs a large number of two- } \\
\text { sample MR analyses (including pleiotropy } \\
\text { robust methods) and produces numerical and } \\
\text { graphical results (39). The data and analytical } \\
\text { platform can be accessed both online and with } \\
\text { the TwoSampleMR R-package. }\end{array}$ \\
\hline MR-TRYX & https://github.com/explodecomputer/tryx & $\begin{array}{l}\text { R-package for undertaking } M R-T R Y X \text { analyses } \\
\text { (114). }\end{array}$ \\
\hline PhenoScanner & http://www.phenoscanner.medschl.cam.ac.uk/ & $\begin{array}{l}\text { A curated database of publicly available } \\
\text { summary-level GWAS results and an analytical }\end{array}$ \\
\hline
\end{tabular}




\begin{tabular}{|c|c|c|}
\hline & & $\begin{array}{l}\text { platform that facilitates 'phenome scans' - the } \\
\text { cross-comparison of genetic variants with } \\
\text { many phenotypes, to help aid understanding of } \\
\text { disease pathways and biology (117). }\end{array}$ \\
\hline PhenoSpD & https://github.com/MRCIEU/PhenoSpD & $\begin{array}{l}\text { An integrated toolkit for phenotypic } \\
\text { correlation estimation and multiple testing } \\
\text { correction using GWAS summary-level } \\
\text { statistics (84). }\end{array}$ \\
\hline PHESANT & https://github.com/MRCIEU/PHESANT & $\begin{array}{l}\text { A tool for performing automated hypothesis- } \\
\text { free } M R \text { phenome-wide scans in UK Biobank } \\
\text { (118). }\end{array}$ \\
\hline RadialMR & https://github.com/WSpiller/RadialMR & $\begin{array}{l}\text { Fitting and visualising Radial MR from } I V W \text { and } \\
\text { MR-Egger methods (104). }\end{array}$ \\
\hline $\begin{array}{l}\text { Sample size and power } \\
\text { calculators }\end{array}$ & $\begin{array}{l}\text { http://cnsgenomics.com/shiny/mRnd/ (one-sample setting) } \\
\text { https://sb452.shinyapps.io/power/ (two-sample setting) }\end{array}$ & $\begin{array}{l}\text { Example calculators for required sample size } \\
\text { given a desired level of power or for statistical } \\
\text { power given a specific sample size in both one- } \\
\text { and two-sample settings. These calculators can }\end{array}$ \\
\hline
\end{tabular}




\begin{tabular}{|l|l|l|}
\hline & & be used for both binary and continuous \\
outcomes (32,82). \\
\hline
\end{tabular}


Figure 11.1: Flow diagram for undertaking one-sample and two-sample Mendelian Randomization

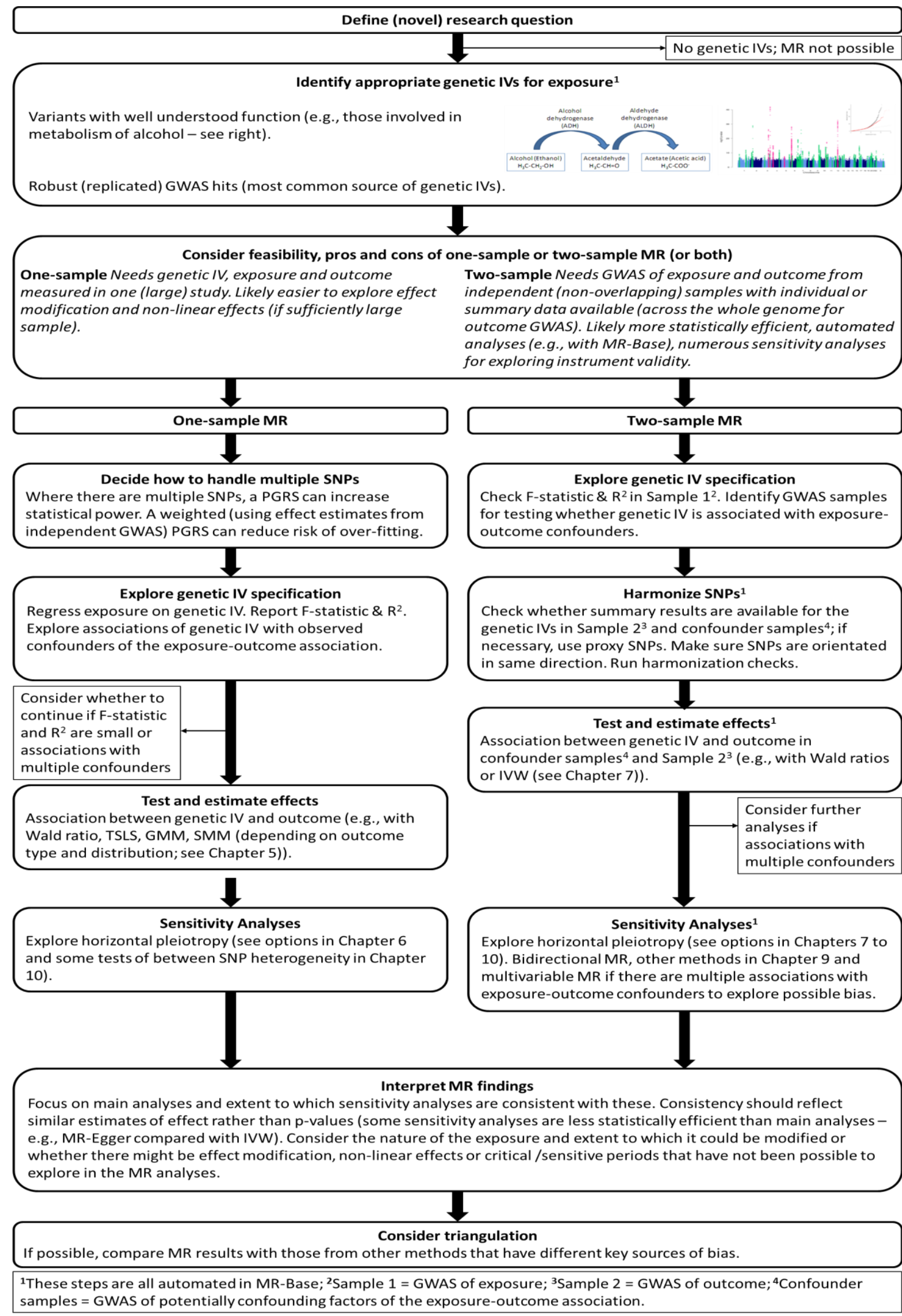




\section{References}

1. Davey Smith G, Ebrahim S. "Mendelian randomisation": can genetic epidemiology contribute to understanding environmental determinants of disease? International Journal of Epidemiology $2003 ; 32: 1-22$.

2. Katan MB. Apolipoprotein E isoforms, serum cholesterol, and cancer. International Journal of Epidemiology 2004;33:9-9.

3. Honkanen R, Pulkkinen P, Järvinen R et al. Does lactose intolerance predispose to low bone density? A population-based study of perimenopausal finnish women. Bone 1996;19:23-28.

4. Xu L, Borges MC, Hemani G, Lawlor DA. The role of glycaemic and lipid risk factors in mediating the effect of BMI on coronary heart disease: a two-step, two-sample Mendelian randomisation study. Diabetologia 2017;60:2210-2220.

5. Freathy RM, Kazeem GR, Morris RW et al. Genetic variation at CHRNA5-CHRNA3-CHRNB4 interacts with smoking status to influence body mass index. Int J Epidemiol 2011;40:1617-28.

6. Lawlor DA, Nordestgaard BG, Benn M, Zuccolo L, Tybjaerg-Hansen A, Davey Smith G. Exploring causal associations between alcohol and coronary heart disease risk factors: findings from a Mendelian randomization study in the Copenhagen General Population Study. European heart journal 2013.

7. Holmes MV, Dale CE, Zuccolo L et al. Association between alcohol and cardiovascular disease: Mendelian randomisation analysis based on individual participant data. BMJ (Clinical research ed) 2014;349:g4164.

8. Borges MC, Lawlor DA, de Oliveira C, White J, Horta BL, Barros AJD. The Role of Adiponectin in Coronary Heart Disease Risk: A Mendelian Randomization Study. Circulation Research 2016;119:491-499.

9. Lawlor DA, Harbord RM, Timpson NJ et al. The association of C-reactive protein and CRP genotype with coronary heart disease: findings from five studies with 4,610 cases amongst 18,637 participants. PLoSONE 2008;3:e3011.

10. Wurtz P, Wang Q, Soininen P et al. Metabolomic Profiling of Statin Use and Genetic Inhibition of HMGCoA Reductase. J Am Coll Cardiol 2016;67:1200-10.

11. Ference BA, Kastelein JJP, Ginsberg HN et al. Association of Genetic Variants Related to CETP Inhibitors and Statins With Lipoprotein Levels and Cardiovascular Risk. JAMA 2017;318:947-956. 
12. Ference BA, Robinson JG, Brook RD et al. Variation in PCSK9 and HMGCR and Risk of Cardiovascular Disease and Diabetes. N Engl J Med 2016;375:2144-2153.

13. Bowden J, Davey Smith G, Haycock PC, Burgess S. Consistent Estimation in Mendelian Randomization with Some Invalid Instruments Using a Weighted Median Estimator. Genet Epidemiol 2016;40:304-14.

14. Bowden J, Del Greco MF, Minelli C, Davey Smith G, Sheehan NA, Thompson JR. Assessing the suitability of summary data for two-sample Mendelian randomization analyses using MR-Egger regression: the role of the I2 statistic. Int J Epidemiol 2016:doi:10.1093/ije/dyw220.

15. Bowden J, Del Greco M F, Minelli C et al. Improving the accuracy of two-sample summary-data Mendelian randomization: moving beyond the NOME assumption. International Journal of Epidemiology 2018:dyy258-dyy258.

16. Hartwig FP, Davies NM, Hemani G, Davey Smith G. Two-sample Mendelian randomization: avoiding the downsides of a powerful, widely applicable but potentially fallible technique. Int J Epidemiol $2016 ; 45: 1717-1726$.

17. Lawlor DA. Two-sample Mendelian randomization: opportunities and challenges. . International Journal of Epidemiology 2016;doi:10.1093/ije/dyw127.

18. Spiller W, Slichter D, Bowden J, Davey Smith G. Detecting and correcting for bias in Mendelian randomization analyses using Gene-by-Environment interactions. International Journal of Epidemiology 2018:dyy204-dyy204.

19. Guo Z, Kang H, Cai TT, Small DS. Confidence Intervals for Causal Effects with Invalid Instruments using Two-Stage Hard Thresholding with Voting. arXiv:160305224 [mathST] 2017.

20. Kang H, Zhang A, Cai TT, Small DS. Instrumental Variables Estimation With Some Invalid Instruments and its Application to Mendelian Randomization. Journal of the Americal Statistics Association $2016 ; 111: 132-142$.

21. van Kippersluis H, Rietveld CA. Pleiotropy-robust Mendelian randomization. Int J Epidemiol 2017.

22. Ference BA, Majeed F, Penumetcha R, Flack JM, Brook RD. Effect of naturally random allocation to lower low-density lipoprotein cholesterol on the risk of coronary heart disease mediated by polymorphisms in NPC1L1, HMGCR, or both: a 2 x 2 factorial Mendelian randomization study. J Am Coll Cardiol 2015;65:1552-61. 
23. Carter AR, Borges M-C, Benn M et al. Investigating the combined association of BMI and alcohol consumption on liver disease and biomarkers: a Mendelian randomization study of over 90,000 adults from the Copenhagen General Population Study. BioRxiv 2018.

24. Relton CL, Davey Smith G. Two-step epigenetic Mendelian randomization: a strategy for establishing the causal role of epigenetic processes in pathways to disease. Int J Epidemiol 2012;41:161-76.

25. Richmond RC, Hemani G, Tilling K, Davey Smith G, Relton CL. Challenges and novel approaches for investigating molecular mediation. Hum Mol Genet 2016;25:R149-R156.

26. Lawlor DA, Richmond R, Warrington $\mathrm{N}$ et al. Using Mendelian randomization to determine causal effects of pregnancy (intrauterine) exposures on offspring outcomes: Sources of bias and methods for assessing them. . Wellcome Open Research 2017;2:11.

27. Warrington NM, Freathy RM, Neale MC, Evans DM. Using structural equation modelling to jointly estimate maternal and fetal effects on birthweight in the UK Biobank. Int J Epidemiol 2018.

28. Nelson MR, Tipney H, Painter JL et al. The support of human genetic evidence for approved drug indications. Nat Genet 2015;47:856-60.

29. Davies NM, Holmes MV, Davey Smith G. Reading Mendelian randomisation studies: a guide, glossary, and checklist for clinicians. BMJ (Clinical research ed) 2018;362:k601.

30. Lawlor DA, Harbord RM, Sterne JAC, Timpson NJ, Davey Smith G. Mendelian randomization: using genes as instruments for making causal inferences in epidemiology. Statistic in Medicine 2008;27:1133-1163.

31. Haycock PC, Burgess S, Wade KH, Bowden J, Relton C, Davey Smith G. Best (but oft-forgotten) practices: the design, analysis, and interpretation of Mendelian randomization studies. Am J Clin Nutr 2016;103:965-78.

32. Zheng J, Baird D, Borges MC et al. Recent Developments in Mendelian Randomization Studies. Curr Epidemiol Rep 2017;4:330-345.

33. Burgess S, Bowden J, Fall T, Ingelsson E, Thompson SG. Sensitivity Analyses for Robust Causal Inference from Mendelian Randomization Analyses with Multiple Genetic Variants. Epidemiology 2017;28:30-42.

34. Buxton J, Turney J. The Rough Guide to Genes \& Cloning 2007.

35. Thapar A, Cooper M. Copy number variation: what is it and what has it told us about child psychiatric disorders? J Am Acad Child Adolesc Psychiatry 2013;52:772-4. 
36. Wain LV, Armour JA, Tobin MD. Genomic copy number variation, human health, and disease. Lancet 2009;374:340-50.

37. Brunner EJ, Kivimaki M, Witte DR et al. Inflammation, insulin resistance, and diabetes--Mendelian randomization using CRP haplotypes points upstream. PLoSMed 2008;5:e155.

38. Ken-Dror G, Humphries SE, Kumari M, Kivimaki M, Drenos F. A genetic instrument for Mendelian randomization of fibrinogen. Eur J Epidemiol 2012;27:267-79.

39. Hemani G, Zheng J, Elsworth B et al. The MR-Base platform supports systematic causal inference across the human phenome. Elife 2018;7.

40. Palmer TM, Lawlor DA, Harbord RM et al. Using multiple genetic variants as instrumental variables for modifiable risk factors. Stat Methods Med Res 2012;21:223-42.

41. Burgess S, Thompson SG. Use of allele scores as instrumental variables for Mendelian randomization. Int J Epidemiol 2013;42:1134-44.

42. Consortium UK, Walter K, Min JL et al. The UK10K project identifies rare variants in health and disease. Nature 2015;526:82-90.

43. Manousaki D, Dudding T, Haworth S et al. Low-Frequency Synonymous Coding Variation in CYP2R1 Has Large Effects on Vitamin D Levels and Risk of Multiple Sclerosis. Am J Hum Genet 2017;101:227-238.

44. Richmond RC, Davey Smith G, Ness AR, den Hoed M, McMahon G, Timpson NJ. Assessing causality in the association between child adiposity and physical activity levels: a Mendelian randomization analysis. PLoS Med 2014;11:e1001618.

45. Davey Smith G, Hemani G. Mendelian randomization: genetic anchors for causal inference in epidemiological studies. Hum Mol Genet 2014;23:R89-R98.

46. Palmer TM, Thompson JR, Tobin MD, Sheehan NA, Burton PR. Adjusting for bias and unmeasured confounding in Mendelian randomization studies with binary responses. International Journal of Epidemiology 2008;37:1161-1168.

47. Bowden J, Vansteelandt S. Mendelian randomization analysis of case-control data using structural mean models. Statistics in Medicine 2011;30:678-694.

48. Burgess S, Labrecque JA. Mendelian randomization with a binary exposure variable: interpretation and presentation of causal estimates. European journal of epidemiology 2018;33:947-952. 
49. Greenland S. An introduction to instrumental variables for epidemiologists. Int J Epidemiol 2000;29:722-729.

50. Small DS, Tan Z, Ramashai RR, Lorch SA, Brookhart MA. Instrumental Variable Estimation with a Stochastic Monotonicity Assumption. Statistical Science 2017;32:561-579.

51. Swanson SA, Hernán MA. The challenging interpretation of instrumental variable estimates under monotonicity. International Journal of Epidemiology 2017;47:1289-1297.

52. Sheehan NA, Didelez V. Epidemiology, genetic epidemiology and Mendelian randomisation: more need than ever to attend to detail. Human Genetics 2019.

53. Burgess S, Thompson SG. Multivariable Mendelian randomization: the use of pleiotropic genetic variants to estimate causal effects. American journal of epidemiology 2015;181:251-60.

54. Sanderson E, Davey Smith G, Windmeijer F, Bowden J. An examination of multivariable Mendelian randomization in the single-sample and two-sample summary data settings. International Journal of Epidemiology 2018.

55. Zhao Q, Wang J, Bowden J, Small DS. Two-Sample Instrumental Variable Analyses using Heterogeneous Samples. arxivorg/pdf/170900081 2018.

56. Burgess S, Daniel RM, Butterworth AS, Thompson SG, Consortium EP-I. Network Mendelian randomization: using genetic variants as instrumental variables to investigate mediation in causal pathways. Int J Epidemiol 2015;44:484-95.

57. Lawlor DA, Windmeijer F, Smith GD. Is Mendelian randomization 'lost in translation?': comments on 'Mendelian randomization equals instrumental variable analysis with genetic instruments' by Wehby et al. Stat Med 2008;27:2750-5.

58. Colhoun HM, McKeigue PM, Davey Smith G. Problems of reporting genetic associations with complex outcomes: can we avoid being swamped by spurious findings? Lancet 2003;361:865-872.

59. Pearce N, Lawlor DA. Causal inference - so much more than statistics. International Journal of Epidemiology 2017;doi: 10.1093/ije/dyw328.

60. Davey Smith G. Use of genetic markers and gene-diet interactions for interrogating population-level causal influences of diet on health. Genes and Nutrition 2011;6:27-43. 
61. Keller MC. Gene x environment interaction studies have not properly controlled for potential confounders: the problem and the (simple) solution. Biol Psychiatry 2014;75:18-24.

62. Barbeira AN, Dickinson SP, Bonazzola R et al. Exploring the phenotypic consequences of tissue specific gene expression variation inferred from GWAS summary statistics. Nature Communications 2018;9:1825.

63. Giambartolomei C, Vukcevic D, Schadt EE et al. Bayesian Test for Colocalisation between Pairs of Genetic Association Studies Using Summary Statistics. PLOS Genetics 2014;10:e1004383.

64. Richardson TG, Zheng J, Davey Smith G et al. Mendelian Randomization Analysis Identifies CpG Sites as Putative Mediators for Genetic Influences on Cardiovascular Disease Risk. The American Journal of Human Genetics 2017;101:590-602.

65. Bush WS, Moore JH. Chapter 11: Genome-Wide Association Studies. PLoS Computational Biology 2012;8:e1002822.

66. Haworth S, Mitchell R, Corbin L et al. Apparent latent structure within the UK Biobank sample has implications for epidemiological analysis. Nature Communications 2019;10:333.

67. Visscher PM, Wray NR, Zhang Q et al. 10 Years of GWAS Discovery: Biology, Function, and Translation. American journal of human genetics 2017;101:5-22.

68. Sterne JAC, Davey Smith G. Shifting the evidence - what's wrong with significance tests? BMJ (Clinical research ed) 2001;322:226-231.

69. Panagiotou OA, Ioannidis JP, Genome-Wide Significance P. What should the genome-wide significance threshold be? Empirical replication of borderline genetic associations. Int J Epidemiol 2012;41:273-86.

70. Marchini J, Howie B. Genotype imputation for genome-wide association studies. Nature Reviews Genetics 2010;11:499.

71. Munafò MR, Nosek BA, Bishop DVM et al. A manifesto for reproducible science. Nature Human Behaviour 2017;1:0021.

72. Lawlor DA, Tilling K, Davey Smith G. Triangulation in aetiological epidemiology. Int J Epidemiol 2017.

73. Hartwig FP, Davies NM, Davey Smith G. Bias in Mendelian randomization due to assortative mating. Under review 2018. 
74. Paternoster L, Tilling K, Davey Smith G. Genetic epidemiology and Mendelian randomization for informing disease therapeutics: Conceptual and methodological challenges. PLoS Genet 2017;13:e1006944.

75. Aschard H, Vilhjalmsson BJ, Joshi AD, Price AL, Kraft P. Adjusting for heritable covariates can bias effect estimates in genome-wide association studies. Am J Hum Genet 2015;96:329-39.

76. Davey Smith G, Lawlor DA, Harbord R, Timpson N, Day I, Ebrahim S. Clustered environments and randomized genes: a fundamental distinction between conventional and genetic epidemiology. PloS Medicine 2008;4:e352-doi:10.1371/journal.pmed.0040352.

77. Nuesch E, Dale C, Palmer TM et al. Adult height, coronary heart disease and stroke: a multi-locus Mendelian randomization meta-analysis. Int J Epidemiol 2015.

78. Evans DM, Moen G-H, Hwang L-D, Lawlor DA, Warrington NM. Elucidating the role of maternal environmental exposures on offspring health and disease using two-sample Mendelian randomization. International Journal of Epidemiology 2019.

79. Burgess S, Thompson SG. Interpreting findings from Mendelian randomization using the MR-Egger method. European journal of epidemiology 2017;32:377-389.

80. Silverwood RJ, Holmes MV, Dale CE et al. Testing for non-linear causal effects using a binary genotype in a Mendelian randomization study: application to alcohol and cardiovascular traits. Int J Epidemiol 2014;43:1781-90.

81. Burgess S, Davies NM, Thompson SG, Consortium EP-I. Instrumental variable analysis with a nonlinear exposure-outcome relationship. Epidemiology 2014;25:877-85.

82. Brion MJ, Shakhbazov K, Visscher PM. Calculating statistical power in Mendelian randomization studies. Int J Epidemiol 2013;42:1497-501.

83. Taylor AE, Davies NM, Ware JJ, VanderWeele T, Smith GD, Munafo MR. Mendelian randomization in health research: using appropriate genetic variants and avoiding biased estimates. Economics and human biology 2014;13:99-106.

84. Zheng J, Richardson TG, Millard LAC et al. PhenoSpD: an integrated toolkit for phenotypic correlation estimation and multiple testing correction using GWAS summary statistics. Gigascience 2018;7. 
85. Bennett DA, Holmes MV. Mendelian randomisation in cardiovascular research: an introduction for clinicians. Heart 2017;103:1400.

86. Hansen LP. Large Sample Properties of Generalized Method of Moments Estimators. Econometrica 1982;50:1029-1054.

87. Clarke PS PT, Windmeijer F. Estimating Structural Mean Models with Multiple Instrumental Variables Using the Generalised Method of Moments. ArXiv 2015;30:96-117.

88. Palmer TM, Ramsahai RR, Didelez V, Sheehan NA. Nonparametric bounds for the causal effect in a binary instrumental-variable model. Stata Journal 2011;11:345-367.

89. Balke A, Pearl J. Bounds on Treatment Effects from Studies with Imperfect Compliance. Journal of the American Statistical Association 1997;92:1171-1176.

90. Tchetgen Tchetgen EJ, Walter S, Vansteelandt S, Martinussen T, Glymour M. Instrumental variable estimation in a survival context. Epidemiology (Cambridge, Mass) 2015;26:402-410.

91. Vansteelandt S, Dukes O, Martinussen T. Survivor bias in Mendelian randomization analysis. Biostatistics 2018;19:426-443.

92. Burgess S, Dudbridge F, Thompson SG. Combining information on multiple instrumental variables in Mendelian randomization: comparison of allele score and summarized data methods. Statistics in medicine 2016;35:1880-1906.

93. Brunner K. The American Economic Review 1955;45:680-682.

94. Tchetgen Tchetgen E, Sun B, Walter S. The GENIUS Approach to Robust Mendelian Randomization Inference. bioRxiv 2017:193953.

95. Cho Y, Shin S-Y, Won S, Relton CL, Davey Smith G, Shin M-J. Alcohol intake and cardiovascular risk factors: A Mendelian randomisation study. Scientific Reports 2015;5:18422.

96. Slichter D. Testing Instrument Validity and Identification with Invalid Instruments. http://wwwsolejoleorg/14436pdf 2014.

97. Burgess S, Butterworth A, Thompson SG. Mendelian Randomization Analysis With Multiple Genetic Variants Using Summarized Data. Genetic Epidemiology 2013;37:658-665.

98. Zhu Z, Zhang F, Hu H et al. Integration of summary data from GWAS and eQTL studies predicts complex trait gene targets. Nature Genetics 2016;48:481. 
99. Burgess S, Small DS, Thompson SG. A review of instrumental variable estimators for Mendelian randomization. Stat Methods Med Res 2015.

100. Zhu Z, Zheng Z, Zhang F et al. Causal associations between risk factors and common diseases inferred from GWAS summary data. Nat Commun 2018;9:224.

101. Bowden J, Del Greco M F, Minelli C, Davey Smith G, Sheehan N, Thompson J. A framework for the investigation of pleiotropy in two-sample summary data Mendelian randomization. Statistics in medicine 2017;36:1783-1802.

102. Hartwig FP, Davey Smith G, Bowden J. Robust inference in summary data Mendelian randomization via the zero modal pleiotropy assumption. International Journal of Epidemiology 2017;46:1985-1998.

103. Schmidt AF, Dudbridge F. Mendelian randomization with Egger pleiotropy correction and weakly informative Bayesian priors. International Journal of Epidemiology 2018;47:1217-1228.

104. Bowden J, Spiller W, Del Greco M F et al. Improving the visualization, interpretation and analysis of twosample summary data Mendelian randomization via the Radial plot and Radial regression. International Journal of Epidemiology 2018;47:1264-1278.

105. Bowden J, Davey Smith G, Burgess S. Mendelian randomization with invalid instruments: effect estimation and bias detection through Egger regression. International Journal of Epidemiology $2015 ; 44: 512-525$.

106. Zhao Q WJ, Hemani G, Bowden J, Small DS. Statistical inference in two-sample summary-data Mendelian randomization using robust adjusted profile score. arXiv 2018.

107. Burgess S, Thompson SG. Multivariable Mendelian Randomization: The Use of Pleiotropic Genetic Variants to Estimate Causal Effects. American Journal of Epidemiology 2015;181:251-260.

108. Rees JMB, Wood AM, Burgess S. Extending the MR-Egger method for multivariable Mendelian randomization to correct for both measured and unmeasured pleiotropy. Statistics in Medicine $2017 ; 36: 4705-4718$.

109. Thompson JR MC, Bowden J, Del Greco FM, Gill D, Jones EM, Shapland CY, Sheehan NA. Mendelian randomization incorporating uncertainty about pleiotropy. Stat Med 2017;36:4627-4645.

110. Hemani G, Bowden J, Haycock PC et al. Automating Mendelian randomization through machine learning to construct a putative causal map of the human phenome. bioRxiv 2017:173682. 
111. Hemani G, Tilling K, Davey Smith G. Orienting the causal relationship between imprecisely measured traits using GWAS summary data. PLOS Genetics 2017;13:e1007081.

112. Greco M FD, Minelli C, Sheehan NA, Thompson JR. Detecting pleiotropy in Mendelian randomisation studies with summary data and a continuous outcome. Statistics in Medicine 2015;34:2926-2940.

113. Verbanck M, Chen C-Y, Neale B, Do R. Detection of widespread horizontal pleiotropy in causal relationships inferred from Mendelian randomization between complex traits and diseases. Nature Genetics 2018;50:693-698.

114. Cho Y, Haycock PC, Gaunt TR et al. MR-TRYX: Exploiting horizontal pleiotropy to infer novel causal pathways. bioRxiv 2018;doi: http://dx.doi.org/10.1101/476085.

115. Early G, Lifecourse Epidemiology Eczema C, Pourcain BS et al. LD Hub: a centralized database and web interface to perform LD score regression that maximizes the potential of summary level GWAS data for SNP heritability and genetic correlation analysis. Bioinformatics 2016;33:272-279.

116. Yavorska 00, Burgess S. MendelianRandomization: an R package for performing Mendelian randomization analyses using summarized data. International journal of epidemiology 2017;46:17341739.

117. Staley JR, Blackshaw J, Kamat MA et al. PhenoScanner: a database of human genotype-phenotype associations. Bioinformatics (Oxford, England) 2016;32:3207-3209.

118. Millard LCA, Davies NM, Gaunt TR, Davey Smith G, Tilling K. Software Application Profile: PHESANT: a tool for performing automated phenome scans in UK Biobank International Journal of Epidemiology 2018;47:29-35. 
Index: List of all terms included in the MR Dictionary in alphabetical order

\begin{tabular}{|c|c|}
\hline Term & Chapter \\
\hline Allele & 1 \\
\hline Assortative mating & 4 \\
\hline Bayesian model averaging for IVW and MR-Egger & 9 \\
\hline Bidirectional MR & 2 \\
\hline Binary exposure MR & 2 \\
\hline Canalization & 4 \\
\hline Candidate gene study & 3 \\
\hline Chromosome & 1 \\
\hline Cochran's Q statistic & 10 \\
\hline Collider & 4 \\
\hline Collider bias & 4 \\
\hline Confounding & 4 \\
\hline Copy number variation (CNV) & 1 \\
\hline Deoxyribonucleic acid (DNA) & 1 \\
\hline Directed acyclic graph (DAG) & 3 \\
\hline Dynastic effects & 4 \\
\hline (no) Effect modification assumption) (Additional IV assumption) & 4 \\
\hline Exclusion restriction (IV3 core assumption) & 4 \\
\hline Factorial MR & 2 \\
\hline Gene & 1 \\
\hline Gene-Environment $(\mathrm{G} \times \mathrm{E})$ interaction study & 3 \\
\hline Generalized Method of Moments (GMM) estimator & 5 \\
\hline Generalized summary MR (GSMR) & 8 \\
\hline Genetic colocalization & 3 \\
\hline
\end{tabular}




\begin{tabular}{|c|c|}
\hline Genetic variant & 1 \\
\hline Genome-wide association studies (GWAS) & 3 \\
\hline Genome-wide significance & 3 \\
\hline Genotype & 1 \\
\hline GSMR & 11 \\
\hline Haplotype & 1 \\
\hline Harmonization failure (in two-sample MR) & 4 \\
\hline HEIDI (heterogeneity in dependent instruments) & 10 \\
\hline Heterozygous/heterozygote & 1 \\
\hline Homogeneity Assumption & 4 \\
\hline Homozygous/homozygote & 1 \\
\hline Horizontal Pleiotropy (a key way in which MR may violate the exclusion restriction assumption) & 4 \\
\hline Imputation of genetic variants in GWAS & 3 \\
\hline Independence (IV2 assumption) & 4 \\
\hline InSIDE assumption (in Two-sample MR using aggregate data) & 4 \\
\hline Instrumental variable (IV) & 2 \\
\hline Inverse variance weighted (IVW) fixed effect estimate & 7 \\
\hline IVW (random effects) & 8 \\
\hline LD Hub & 11 \\
\hline Linkage disequilibrium (LD), also known as gametic phase disequilibrium & 1 \\
\hline Locus & 1 \\
\hline Maximum likelihood-based MR & 7 \\
\hline Mendelian randomization (MR) & 2 \\
\hline MendelianRandomization & 11 \\
\hline Mode-based estimate & 8 \\
\hline Monotonicity (IV4 assumption) & 4 \\
\hline MR for testing critical or sensitive periods & 4 \\
\hline
\end{tabular}




\begin{tabular}{|c|c|}
\hline MR for testing developmental origins & 4 \\
\hline MR GENIUS & 6 \\
\hline MR GxE & 6 \\
\hline MR with a time-to-event outcome & 5 \\
\hline MR-Base and TwoSampleMR & 11 \\
\hline MR-Egger regression and extensions & 8 \\
\hline MR-MoE & 9 \\
\hline MR-PRESSO & 10 \\
\hline MR-RAPS & 8 \\
\hline MR-TRYX & 11 \\
\hline MR-TRYX (Treasure your exceptions) & 10 \\
\hline Multivariable MR & 2 \\
\hline Multivariable MR (MVMR) and extensions & 8 \\
\hline Non-linear effects & 4 \\
\hline Non-overlapping samples (in two-sample MR) & 4 \\
\hline Non-parametric methods with bounds of causal effect & 5 \\
\hline One-sample MR & 2 \\
\hline Overfitting & 4 \\
\hline Palindromic SNP & 1 \\
\hline PhenoScanner & 11 \\
\hline PhenoSpD & 11 \\
\hline PHESANT & 11 \\
\hline Pleiotropy & 4 \\
\hline $\begin{array}{l}\text { Polygenic risk score (PGRS), also known as a genetic risk score, risk score, genetic score, genetic } \\
\text { values, breeding values }\end{array}$ & 1 \\
\hline Polygenic risk score approach & 5 \\
\hline Polymorphism & 1 \\
\hline
\end{tabular}




\begin{tabular}{|c|c|}
\hline Population stratification & 4 \\
\hline PRMR & 6 \\
\hline Radial MR (MR pleiotropy residual sum and outlier) & 10 \\
\hline RadialMR & 11 \\
\hline Rare variants & 1 \\
\hline Regression dilution bias (attenuation by errors) & 4 \\
\hline Relevance (IV1 assumption) & 4 \\
\hline Replication & 3 \\
\hline Reverse causality & 4 \\
\hline Rucker framework for IVW and MR-Egger & 9 \\
\hline Same underlying population (in two-sample MR) & 4 \\
\hline Sample size and power calculators & 11 \\
\hline $\begin{array}{l}\text { Semi-parametric structural mean model (Semi-parametric structural mean model (SMMs) for } \\
\text { binary outcomes }\end{array}$ & 5 \\
\hline Single nucleotide polymorphism (SNP) & 1 \\
\hline SISVIVE & 6 \\
\hline Statistical power/efficiency & 4 \\
\hline Steiger filtering & 9 \\
\hline Summary MR (SMR) & 7 \\
\hline Triangulation & 3 \\
\hline Two-stage Hard Thresholding (TSHT) with voting & 6 \\
\hline TSLS with binary outcome & 5 \\
\hline Two-sample MR & 2 \\
\hline Two-sample MR with individual participant data (IPD) & 2 \\
\hline Two-sample MR with summary (aggregate) data & 2 \\
\hline Two-stage least squares (TSLS) & 5 \\
\hline Two-step / Mediation MR & 2 \\
\hline
\end{tabular}




\begin{tabular}{|l|l|}
\hline Unweighted regression & 7 \\
\hline Vertical Pleiotropy & 4 \\
\hline Wald ratio (or Ratio) estimate & 7 \\
\hline Weak instrument bias & 4 \\
\hline Weighted median & 8 \\
\hline Winner's curse & 4 \\
\hline
\end{tabular}

